SAMUEL BARSANELLI COSTA

MODELO UNIDIMENSIONAL PRELIMINAR DE TRANSPORTE DE SEDIMENTOS PARA O RESERVATÓRIO TAIAÇUPEBA 
SAMUEL BARSANELLI COSTA

MODELO UNIDIMENSIONAL PRELIMINAR DE TRANSPORTE DE SEDIMENTOS PARA O RESERVATÓRIO TAIAÇUPEBA

\author{
Dissertação apresentada à Escola \\ Politécnica da Universidade de São \\ Paulo para obtenção do título de Mestre \\ em Ciências
}


SAMUEL BARSANELLI COSTA

\title{
MODELO UNIDIMENSIONAL PRELIMINAR DE TRANSPORTE DE SEDIMENTOS PARA O RESERVATÓRIO TAIAÇUPEBA
}

\author{
Dissertação apresentada à Escola \\ Politécnica da Universidade de São \\ Paulo para obtenção do título de Mestre \\ em Ciências
}

Área de concentração:

Engenharia Hidráulica e Ambiental

Orientador:

Prof. Dr. Paolo Alfredini 
Este exemplar foi revisado e corrigido em relação à versão original, sob responsabilidade única do autor e com a anuência de seu orientador

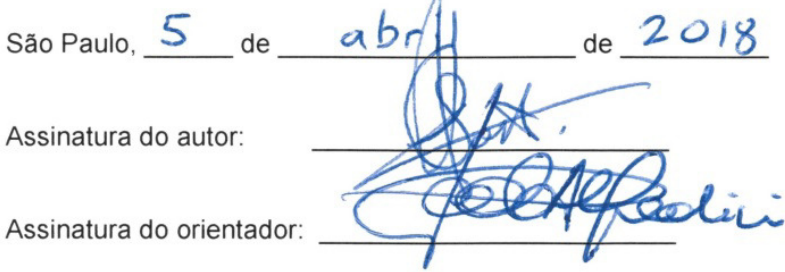

Catalogação-na-publicação

\section{Costa, Samuel Barsanelli}

Modelo unidimensional preliminar de transporte de sedimentos para o reservatório Taiaçupeba / S. B. Costa -- versão corr. -- São Paulo, 2018. $89 p$

Dissertação (Mestrado) - Escola Politécnica da Universidade de São Paulo. Departamento de Engenharia de Hidráulica e Ambiental.

1. Hidráulica Fluvial 2.Sedimentologia Fluvial 3.Transporte de Sedimentos 4.Modelos Matemáticos 5.Reservatórios I.Universidade de São Paulo. Escola Politécnica. Departamento de Engenharia de Hidráulica e Ambiental II.t. 


\section{AGRADECIMENTOS}

Ao orientador, Prof. Dr. Paolo Alfredini, pelo empenho dispensado durante o desenvolvimento desta pesquisa, ao Prof. Dr. Carlos Lloret Ramos, pela indispensável colaboração técnica, à Divisão de Recursos Hídricos Metropolitanos Leste da Sabesp, pela cessão de dados operacionais do reservatório Taiaçupeba, e às equipes da Seção de Investigação, Riscos e Desastres Naturais e do Laboratório de Resíduos e Áreas Contaminadas do Instituto de Pesquisas Tecnológicas, pelo apoio institucional na realização da pesquisa e operacional nas campanhas e análises laboratoriais. 


\section{RESUMO}

COSTA, S. B. Modelo unidimensional preliminar de transporte de sedimentos para o reservatório Taiaçupeba. Dissertação (Mestrado) - Escola Politécnica, Universidade de São Paulo, São Paulo, 2018.

A modelagem unidimensional tem sido adotada desde os anos 1980, com sucesso nas práticas de engenharia, para a caracterização do regime de transporte de sedimentos de longo termo. É também uma importante ferramenta para $O$ entendimento da dinâmica sedimentar de bacias e gestão de sedimentos em reservatórios. Esta pesquisa teve como objetivo aplicar a modelagem unidimensional de transporte de sedimentos na bacia do reservatório Taiaçupeba, São Paulo, Brasil, a partir do sistema computacional HEC-RAS, orientada à estimativa das descargas sólidas afluentes ao reservatório. O período de coleta de dados coincidiu com a estiagem de 2013-2015 na Região Sudeste, o que contribuiu com a análise crítica do método e dos resultados, cuja discussão ressalta o uso da modelagem unidimensional como instrumento eficaz de validação das curvas de sedimento para caracterização do regime de transporte. As funções de capacidade de transporte de Laursen-Copeland e Toffaleti mostraram-se aplicáveis a esse sistema fluvial, bem como os métodos de encouraçamento de fundo de Hirano e Thomas-Copeland. Os coeficientes de Manning ajustados foram considerados preliminares e dados de campo adicionais são encorajados para refinar seu ajuste e incorporar maior acurácia na estimativa do perfil da linha d'água em trabalhos futuros. Além disso, são apresentadas recomendações metodológicas ao monitoramento fluvissedimentométrico que contribuem com a sistematização das técnicas e tecnologias disponíveis à pesquisa hidrossedimentológica.

Palavras-chave: Hidráulica Fluvial; Sedimentologia Fluvial; Transporte de Sedimentos; Modelos Matemáticos; Reservatórios. 


\begin{abstract}
COSTA, S. B. Preliminary one-dimensional sediment transport model for the Taiacupeba reservoir. Thesis (Masters Degree) - Polytechnic School, University of Sao Paulo, Sao Paulo, 2018.

One-dimensional modeling has been successfully adopted since the 1980s in engineering practices to assess long-term sediment transport regimes. It is also an important tool for the understanding of sediment dynamics in watersheds and sediment management in reservoirs. The objective of this research was to apply the one-dimensional sediment transport modeling in the Taiacupeba reservoir basin, located in Sao Paulo, Brazil, implemented on HEC-RAS, aiming to estimate longterm loads into the reservoir. The data collection period coincided with the drought of 2013-2015 in Southeastern Brazil, which contributed to the critical analysis of the method and results, whose discussion highlights the use of one-dimensional modeling as an effective instrument for validating sediment curves. The transport capacity functions of Laursen-Copeland and Toffaleti have been shown to be applicable to this river system, as well as the bed sorting and armoring methods of Hirano and Thomas-Copeland. The Manning coefficients were considered preliminary and additional field data are encouraged to enhance its adjustment and incorporate greater accuracy in estimating the water surface profile in future work. Besides, methodological recommendations for sediment monitoring are presented, contributing to the systematization of available techniques and technologies applied to sediment research.
\end{abstract}

Keywords: Fluvial Hydraulics; Fluvial Sedimentology; Sediment Transport; Mathematical Models; Reservoirs. 


\section{LISTA DE SIGLAS}

$\begin{array}{ll}\text { ADCP } & \text { Acoustic Doppler Current Profiler } \\ \text { ADV } & \text { Acoustic Doppler Velocimeter } \\ \text { ADVM } & \text { Acoustic Doppler Velocity Meter } \\ \text { DAEE } & \text { Departamento de Águas e Energia Elétrica do Estado de São Paulo } \\ \text { DGPS } & \text { Differential Global Positioning System } \\ \text { GNSS } & \text { Global Navigation Satellite System } \\ \text { GRS80 } & \text { Geodetic Reference System 1980 } \\ \text { HEC-RAS } & \text { Hydrologic Engineering Center - River Analysis System } \\ \text { PDOP } & \text { Position Dilution of Precision } \\ \text { RBMC } & \text { Rede Brasileira de Monitoramento Contínuo } \\ \text { RTK } & \text { Real Time Kinematic } \\ \text { SIRGAS2000 } & \text { Sistema de Referência Geocêntrico para as Américas } 2000 \\ \text { UTM } & \text { Universal Transversa de Mercator }\end{array}$




\section{LISTA DE SÍMBOLOS}

$g \quad$ Aceleração da gravidade $\left(\mathrm{m} / \mathrm{s}^{2}\right)$

$\Delta Z_{a} \quad$ Agradação máxima absoluta do leito do canal (m)

$\varepsilon \quad$ Altitude elipsoidal ( $\mathrm{m})$

$\theta \quad$ Altitude ortométrica $(\mathrm{m})$

$H B \quad$ Altura da baliza ao solo $(\mathrm{m})$

$H I \quad$ Altura do instrumento topográfico ao solo $(\mathrm{m})$

$\delta \quad$ Altura geoidal $(\mathrm{m})$

AI Área do incremento de largura $\left(\mathrm{m}^{2}\right)$

A Área molhada da seção transversal $\left(\mathrm{m}^{2}\right)$

$T_{c} \quad$ Capacidade de transporte total de sedimentos (t/d)

$\alpha \quad$ Coeficiente de Coriolis

$C_{d} \quad$ Coeficiente de deposição

$C_{e} \quad$ Coeficiente de erosão

$n \quad$ Coeficiente de Manning

$a, b \quad$ Coeficientes de regressão

$l \quad$ Comprimento do volume de controle $(\mathrm{m})$

$L \quad$ Comprimento longitudinal do talvegue $(\mathrm{m})$

CSS Concentração de sedimentos em suspensão (mg/L)

$\overline{C S S} \quad$ Concentração de sedimentos em suspensão média ( $\mathrm{mg} / \mathrm{L})$

CSS' Concentração de sedimentos em suspensão modelada $(\mathrm{mg} / \mathrm{L})$

CST Concentração de sedimentos total ( $\mathrm{mg} / \mathrm{L})$

$k \quad$ Constante de Von Karman

$Z \quad$ Cota do leito do canal $(\mathrm{m})$

$S_{f} \quad$ Declividade da linha de energia $(\mathrm{m} / \mathrm{m})$

$S_{0} \quad$ Declividade do canal $(\mathrm{m} / \mathrm{m})$

$\Delta Z_{d} \quad$ Degradação máxima absoluta do leito do canal $(\mathrm{m})$

$q_{b} \quad$ Descarga sólida de arrasto unitária (t/d.m)

$Q_{s s} \quad$ Descarga sólida em suspensão (t/d)

$q_{s s} \quad$ Descarga sólida em suspensão unitária (t/d.m)

$Q_{s} \quad$ Descarga sólida total (t/d)

DV Desnível do equipamento topográfico ao ponto visado $(\mathrm{m})$

$d \quad$ Diâmetro do grão $(\mathrm{m})$

$d_{50} \quad$ Diâmetro do grão que iguala ou excede a frequência de $50 \%(\mathrm{~m})$

$d_{90} \quad$ Diâmetro do grão que iguala ou excede a frequência de $90 \%(\mathrm{~m})$ 


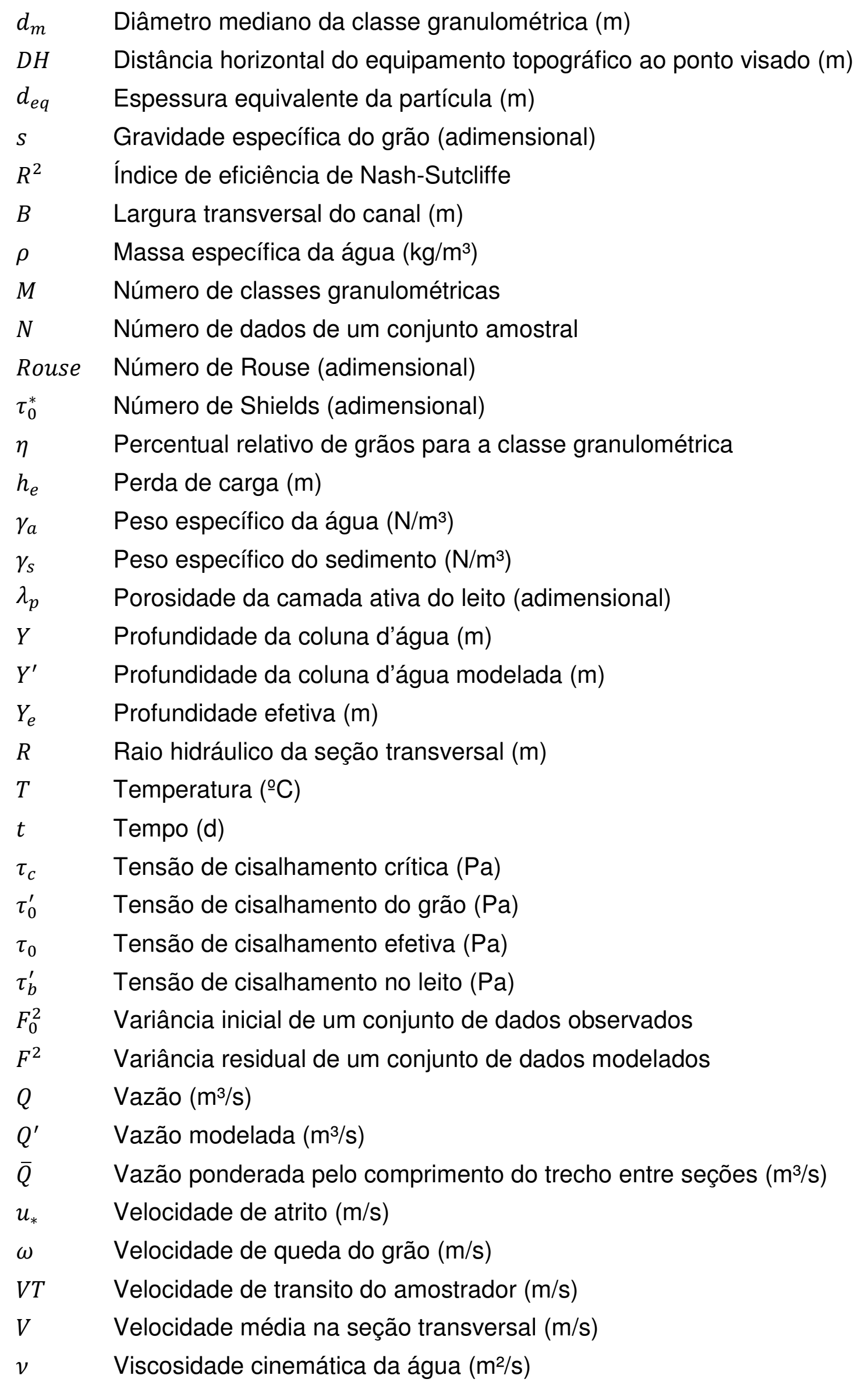




\section{SUMÁRIO}

1 INTRODUÇÃO

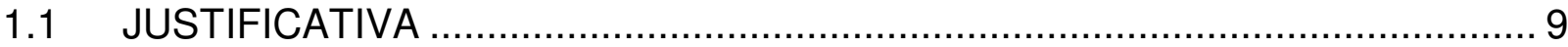

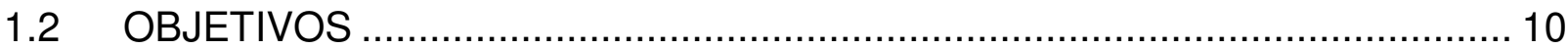

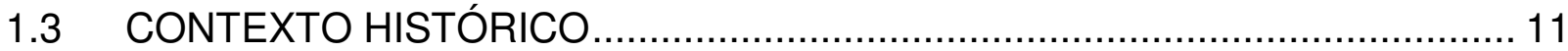

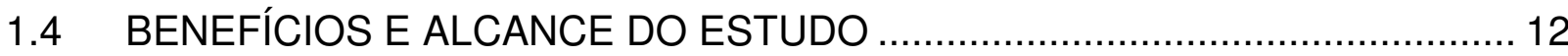

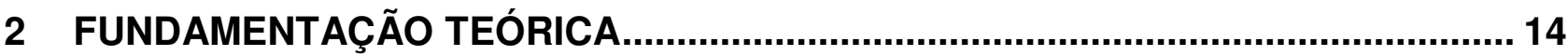

2.1 MODELAGEM DO TRANSPORTE DE SEDIMENTOS …............................ 15

2.2 FUNÇÕES DE CAPACIDADE DE TRANSPORTE ....................................... 20

3 ÁREA DE ESTUDO

3.1 GENERALIDADES E ANTECEDENTES HISTÓRICOS ……...................... 26

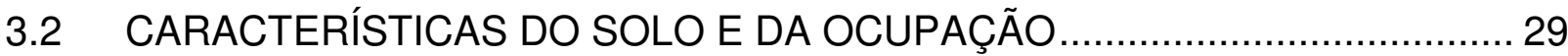

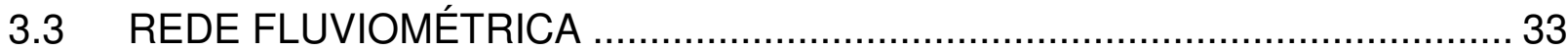

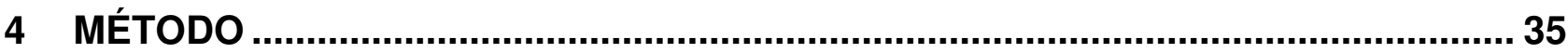

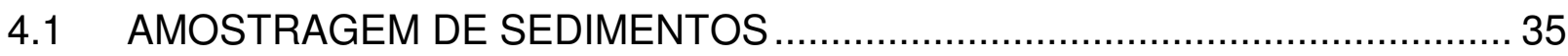

4.2 LEVANTAMENTO DAS SEÇÕES TRANSVERSAIS ….............................. 42

4.3 CALIBRAÇÃO, AJUSTE E VERIFICAÇÃO DO MODELO …............................45

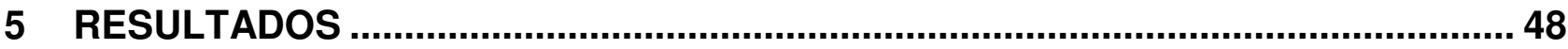

5.1 MONITORAMENTO FLUVISSEDIMENTOMÉTRICO .................................. 48

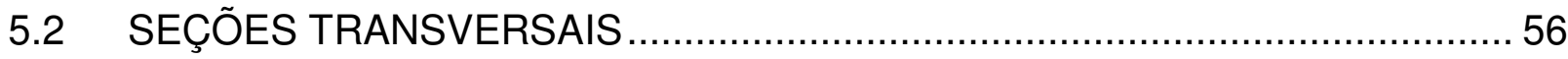

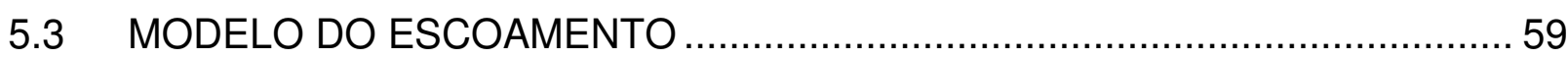

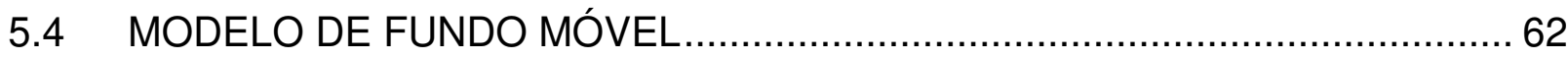

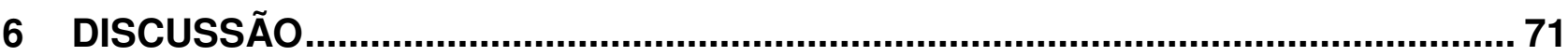

6.1 CARACTERIZAÇÃO DO TRANSPORTE DE SEDIMENTOS ….....................71

6.2 MODELAGEM DO TRANSPORTE DE SEDIMENTOS ……….................... 72

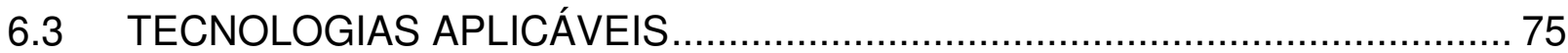

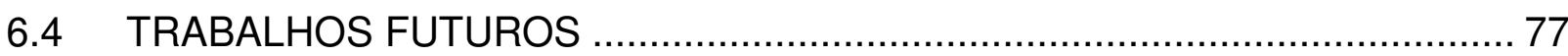

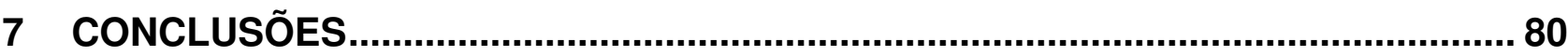

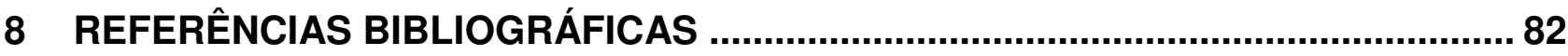

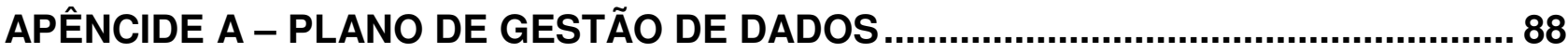




\section{INTRODUÇÃO}

O transporte de sedimentos é um fenômeno natural, que se processa na forma de cargas em suspensão e de arrasto no leito, modelando canais, planícies fluviais e áreas costeiras. Os rios são os principais agentes de transporte de materiais intemperizados das bacias, cujo fluxo ocorre das áreas mais elevadas às mais baixas. Mudanças no seu regime de escoamento, provocadas por alterações na geometria ou pela introdução de obstáculos ao fluxo, alteram, também, o equilíbrio da dinâmica sedimentar.

No caso específico de barramentos, o sedimento afluente aos reservatórios pode ter sua mobilidade reduzida devido à desaceleração do escoamento, promovendo depósitos nos deltas fluviais e no interior do lago, comprometendo a vida útil do aproveitamento hidráulico. Associado a esse fato, a dinâmica de uso e ocupação do solo nas bacias pode acelerar os processos morfodinâmicos superficiais de erosão, intensificando o desequilíbrio dos processos de transporte.

Nesse sentido, a hidrossedimentologia, área da Engenharia Hidráulica que se propõe ao estudo do transporte de sedimentos fluviais, pode colaborar no diagnóstico e na análise preditiva da resposta sedimentar, frente às interferências no regime fluvial, fornecendo subsídios à gestão operacional de aproveitamentos hidráulicos, a fim de evitar prejuízos econômicos e sociais decorrentes da perda de volume útil dos reservatórios.

\subsection{JUSTIFICATIVA}

Os estudos hidrossedimentológicos ganharam destaque, no Brasil, com a publicação da Resolução Conjunta da Agência Nacional de Energia Elétrica e da Agência Nacional de Águas, $\mathrm{n} .-003 / 2010$, que instituiu a obrigatoriedade do monitoramento fluvissedimentométrico ${ }^{1}$, associado a aproveitamentos hidrelétricos. Contudo, apesar de enquadrar a coleta de dados como exigência legal, a norma

${ }^{1} \mathrm{O}$ termo fluvissedimentométrico engloba o monitoramento fluviométrico (nível e vazão) e sedimentométrico (sedimentos em suspensão e arrasto), e foi difundido pela Agência Nacional de Energia Elétrica (2000). 
nada dispõe sobre sua representatividade como, por exemplo, pela aplicação de modelos hidrossedimentológicos como ferramenta de avaliação da acurácia das curvas de sedimento.

Além disso, pela norma ser aplicável restritivamente aos aproveitamentos hidrelétricos, o monitoramento ainda não se difundiu entre os concessionários de abastecimento público. Independentemente do uso à que se destina a água, a resiliência dos aproveitamentos hidráulicos depende do conhecimento da dinâmica sedimentar, e tanto o monitoramento fluvissedimentométrico, quanto os modelos hidrossedimentológicos, devem ser entendidos como ferramentas de gestão, importantes ao manejo de sedimentos nos reservatórios, em estratégias de médio e longo prazo.

Nesse contexto, justifica-se a necessidade da pesquisa científica para a sistematização e avaliação de técnicas e tecnologias essenciais à investigação da sedimentação em reservatórios e ambientes fluviais, no que tange ao estudo da dinâmica de transporte de sedimentos em bacias, e à aplicação de modelos hidrossedimentológicos que forneçam subsídios ao gerenciamento de mananciais estratégicos para a segurança hídrica.

\subsection{OBJETIVOS}

O objetivo principal desta pesquisa foi aplicar a modelagem unidimensional de transporte de sedimentos para o reservatório Taiaçupeba, São Paulo, Brasil, a partir do sistema computacional HEC-RAS, orientado à caracterização do regime de transporte de sedimentos de seus principais tributários e à estimativa das descargas sólidas afluentes de longo termo.

Além disso, pretendeu-se contribuir com a sistematização do método de aquisição de dados fluvissedimentométricos, cuja consistência e representatividade são fundamentais ao atendimento do objetivo principal, e apoiar a gestão de sedimentos do reservatório Taiaçupeba, definido como área de estudo por sua importância no abastecimento público da Região Metropolitana de São Paulo e por carecer de estudos hidrossedimentológicos. 


\subsection{CONTEXTO HISTÓRICO}

Segundo Morris, Annandale e Hotchkiss (2008), barragens representam uma categoria única de infraestruturas de engenharia, porque a sua eventual obsolescência é determinada pelos processos geológicos de erosão e sedimentação, e não pelos métodos construtivos, podendo ser continuamente reabilitadas. Se a sedimentação é conhecida e controlada, sua vida útil excede sobremaneira a vida útil de qualquer outro tipo de obra de engenharia. É por esse motivo, segundo Carvalho (2008), que a avaliação dos processos de sedimentação em reservatórios é uma das aplicações mais tradicionais em estudos hidrossedimentológicos.

Segundo Gill (1979), os processos que determinam, em última instância, a vida útil de um reservatório, são fenômenos complexos e que dependem de um grande número de variáveis, com alto custo operacional de aquisição. Os primeiros modelos empíricos desenvolveram-se, originalmente, em um período de intensa construção de barragens ao redor do mundo, quando as investigações se concentravam na determinação da vida útil de projeto, para fins exclusivamente econômicos.

Dentre os mais utilizados estavam o de Churchill (1948), que se baseou na razão entre o tempo de retenção e a velocidade média de fluxo através do reservatório, e o de Brune (1953), que desenvolveu uma relação empírica entre a eficiência de retenção de longo prazo e o tempo de residência no reservatório. Contudo, segundo García (2008), apesar de considerarem as mudanças de longo prazo na eficiência de retenção, à medida que há perdas reais na capacidade de armazenamento do reservatório, esses métodos são limitados e indicados unicamente para estimativas preliminares de projeto.

Após a década de 1970, a construção de barragens caiu drasticamente em todo o mundo, face aos obstáculos locacionais, econômicos, sociais, políticos e ambientais, fazendo com que a engenharia passasse a enfrentar os problemas de sedimentação de longo termo, antes ignorados, ou apenas discretamente observados, na concepção dos projetos, conforme discutido por Morris, Annandale e Hotchkiss (2008).

O novo paradigma que se colocou foi $\mathrm{o}$ de prolongar a vida útil de reservatórios estratégicos, culminando no desenvolvimento de modelos matemáticos 
mais robustos para descrever o transporte de sedimentos nos ambientes fluviais. De forma geral, esses modelos buscam descrever o escoamento da mistura águasedimento, segundo as equações gerais do movimento e da continuidade (princípios da conservação da massa e da quantidade de movimento), associando equações empíricas oriundas de experimentos de laboratório e dados de campo.

Na escala da bacia, segundo Thomas e Chang (2008), esses modelos podem ser aplicados para prever as modificações na morfologia dos canais, descritas pelos processos de erosão, arraste, suspensão, deposição e compactação. Já na escala do reservatório, podem ser utilizados para prever o comportamento dinâmico dos sedimentos no corpo central do lago. Para cada uma dessas escalas, há um nível diferente de complexidade, e uma abordagem dimensional mais apropriada.

De acordo com Spasojevic e Holly Jr. (2008), a modelagem unidimensional tem sido adotada desde os anos 1980, com sucesso nas práticas de engenharia, para a determinação de respostas de longo termo que envolvem extensos trechos fluviais. Enquanto isso, as abordagens bi e tridimensionais têm sido utilizadas na solução de problemas localizados, como na representação da distribuição dos padrões em fundo móvel e no comportamento dos sedimentos próximos aos descarregadores de fundo de barragens.

A escolha da melhor abordagem depende da definição dos objetivos da pesquisa, sendo que o aumento da complexidade do modelo deve ser inversamente proporcional à escala do estudo. Na prática, a complexidade deve ser incremental, trabalhando-se sempre no limite da simplicidade.

Uma vez que o sistema fluvial do reservatório Taiaçupeba carece de estudos hidrossedimentológicos, entende-se que a primeira etapa na produção de ferramentas para o seu gerenciamento deva concentrar-se no desenvolvimento de um modelo unidimensional, que represente as descargas sólidas afluentes de longo termo.

\subsection{BENEFÍCIOS E ALCANCE DO ESTUDO}

A gestão de sedimentos em reservatórios ainda não é prática comum no Brasil. Sistematizar as bases técnicas e científicas na coleta de dados e parametrização de modelos, portanto, figura como um importante passo na definição 
de métodos para caracterização do regime de transporte de sedimentos, que posteriormente subsidiarão a avaliação de alternativas de manejo que garantam a resiliência dessas obras.

Do ponto de vista metodológico, o roteiro sistematizado nesta pesquisa serve como um guia de orientação, replicável ao estudo hidrossedimentológico de qualquer aproveitamento hidráulico. Além disso, seus resultados são inéditos na caracterização do transporte de sedimentos da bacia do Taiaçupeba, fornecendo importante orientação a trabalhos futuros na área de estudo.

Quanto ao sistema computacional selecionado para a modelagem, a escolha do HEC-RAS contribui com a difusão de um software gratuito e amplamente utilizado na engenharia, como pode ser constatado nos trabalhos de Pinzón et al. (2009), Trigg et al. (2009), Gibson et al. (2010), Meselhe et al. (2010), Amini et al. (2014), Rashid et al. (2014), Davis et al. (2014) e Castillo et al. (2015). 


\section{FUNDAMENTAÇÃO TEÓRICA}

A modelagem hidráulica unidimensional tem como objetivo primário estimar o perfil da linha d'água ao longo de um canal. Em condições de escoamento permanente, uniforme ou gradualmente variado, pode-se resolver a linha d'água pela Equação da Energia (1), entre duas seções transversais consecutivas (Figura 2-1):

$$
Z_{2}+Y_{2}+\frac{\alpha_{2} V_{2}^{2}}{2 g}=Z_{1}+Y_{1}+\frac{\alpha_{1} V_{1}^{2}}{2 g}+h_{e}
$$

onde $Z_{1}$ e $Z_{2}$ são as cotas do talvegue (termo de energia potencial de posição), respectivamente para a seção transversal de jusante e montante, $Y_{1}$ e $Y_{2}$ são as profundidades da coluna d'água (termo de energia de pressão), $V_{1}$ e $V_{2}$ são as velocidades médias nas seções, $\alpha_{1}$ e $\alpha_{2}$ são os coeficientes de Coriolis, $g$ é a aceleração da gravidade (onde $\alpha V^{2} / 2 g$ representa o termo de energia cinética) e $h_{e}$ é a perda de carga distribuída e devida às contrações e expansões entre as seções.

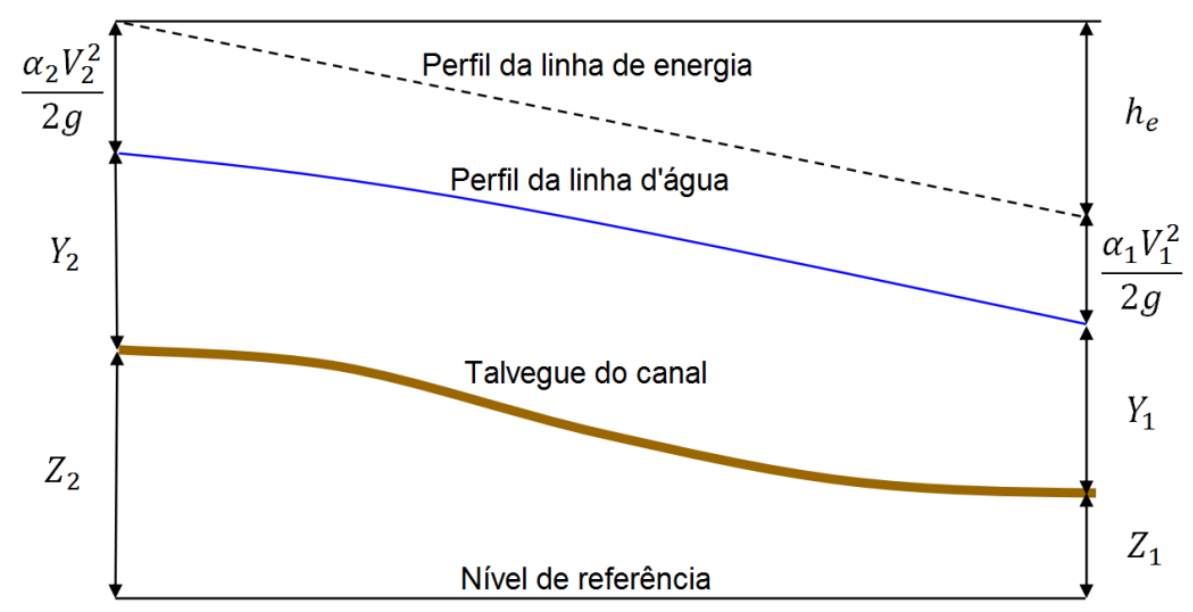

Figura 2-1 - Representação dos termos da Equação da Energia. Fonte: adaptado de Brunner (2010).

A perda de carga, por sua vez, pode ser determinada estimando-se a declividade da linha de energia $\left(S_{f}\right.$ ) pela Equação de Manning (2), abordagem comumente adotada por modelos unidimensionais: 


$$
Q=\frac{1}{n} A R^{2 / 3} S_{f}^{1 / 2}
$$

onde $Q$ é a vazão, $n$ é o coeficiente de Manning (fator que exprime a resistência ao escoamento), $A$ é a área molhada da seção transversal, $R$ o raio hidráulico (razão entre área e perímetro molhado). $O$ coeficiente $n$ é o principal parâmetro de ajuste na modelagem da linha d'água.

\subsection{MODELAGEM DO TRANSPORTE DE SEDIMENTOS}

Segundo Brunner (2010), por razões de simplicidade no desenvolvimento do cálculo e do processamento computacional, modelos unidimensionais podem adotar uma abordagem, na solução do transporte de sedimentos, que aproxima um hidrograma contínuo por uma série de perfis discretos de escoamento permanente, simplificação hidrodinâmica denominada de escoamento quase permanente. A discretização do escoamento, no tempo, é realizada da seguinte forma:

- duração do escoamento: intervalo de tempo onde a cota da linha d'água permanece constante, geralmente associado à frequência da série de vazões;

- incremento computacional: subintervalo de tempo onde ocorre a atualização da geometria do leito.

Uma vez que o cálculo do escoamento quase permanente passa pela definição de uma série de perfis discretos de escoamento permanente, ele depende, preliminarmente, do ajuste do coeficiente $n$ de Manning para a solução da linha d'água. A partir disso, o transporte total de sedimentos pode ser solucionado pela Equação da Continuidade de Sedimento, ou Equação de Exner (3):

$$
\left(1-\lambda_{p}\right) B \frac{\partial Z}{\partial t}=-\frac{\partial Q_{s}}{\partial x}
$$

onde $\lambda_{p}$ é a porosidade da camada ativa do leito (material que está disponível ao transporte), $B$ é a largura do canal, $Q_{s}$ é a descarga sólida total (suspensão e arrasto), $t$ é o tempo e $x$ é a distância longitudinal ao canal. $O$ lado direito da equação representa o gradiente de sedimentos ao longo de um volume de controle, 
sendo a entrada igual à saída do volume de controle a montante, e a saída igual à máxima quantidade de sedimento capaz de deixar o volume de controle, denominada de máxima capacidade de transporte de sedimento, que depende da energia do escoamento.

A capacidade de transporte de sedimentos é comumente baseada na hipótese clássica de Einstein, assumindo, segundo García (2008), que a descarga sólida de determinada classe granulométrica é proporcional ao percentual relativo dessa classe no leito do canal, Equação (4):

$$
T_{c}=\sum_{j=1}^{M} \eta_{j} T_{j}
$$

onde $T_{c}$ é a capacidade de transporte total de sedimentos, $M$ é o número de classes granulométricas, $\eta_{j}$ é o percentual relativo de sedimentos da classe $j$, disponível na camada ativa do leito, e $T_{j}$ é a capacidade de transporte de sedimentos calculado para a classe $j$. Modelos de transporte de sedimentos utilizam a classificação granulométrica padronizada pela American Geophysical Union, geralmente limitada entre $0,002 \mathrm{~mm}$ e $2,048 \mathrm{~mm}$, da argila (clay) à blocos de pedra (large boulder). As funções empíricas mais utilizadas no cálculo da capacidade de transporte serão abordadas em detalhe no item 2.2.

Contudo, segundo Brunner (2010), a máxima capacidade de transporte de sedimentos não pode ser diretamente convertida em alteração na morfologia de fundo, uma vez que deposição e erosão são processos limitados pelo tempo. No primeiro caso, a limitação é imposta pela velocidade de queda da partícula $(\omega)$ e pela distância vertical que a ela deve percorrer para se depositar (Figura 2-2), também denominada de profundidade efetiva $\left(Y_{e}\right)$. 


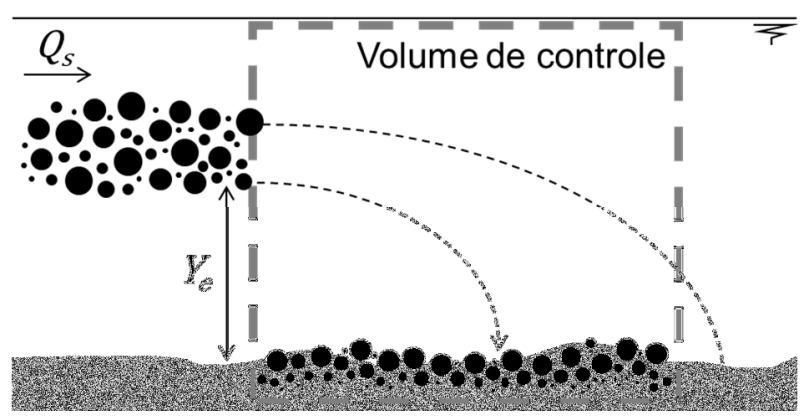

Figura 2-2 - Representação da limitação imposta à deposição de partículas em modelos unidimensionais de transporte de sedimentos.

A relação entre velocidade de queda e profundidade efetiva pode ser escrita na forma analítica de um coeficiente de deposição $\left(C_{d}\right)$, Equação (5), que representa o percentual das partículas superavitárias no volume de controle, da classe granulométrica $j$, que pode efetivamente se depositar:

$$
C_{d, j}=\frac{\omega_{j} \Delta t}{Y_{e, j}}
$$

A velocidade de queda da partícula é, também, preponderante na determinação do início do movimento do sedimento. Ela pode ser descrita pela Equação de Rubey (6), derivada da Lei de Stokes:

$$
\omega=\left(\sqrt{\frac{2}{3}+\frac{36 v^{2}}{(s-1) g d^{3}}}-\sqrt{\frac{36 v^{2}}{(s-1) g d^{3}}}\right) \sqrt{(s-1) g d}
$$

onde $d$ é o diâmetro do grão, $s$ é a gravidade específica ${ }^{2}$ e $v$ é o coeficiente de viscosidade cinemática da água. Uma das premissas para o início do movimento é que a suspensão de uma partícula se inicia à medida que a velocidade de atrito $\left(u_{*}\right)$, Equação (7), se aproxima da velocidade de queda, seguindo a relação expressa pelo Número de Rouse, Equação (8):

${ }^{2}$ Gravidade específica, ou densidade relativa do grão, é a razão entre a massa específica do grão e a massa específica da água. 


$$
\begin{gathered}
u_{*}=\sqrt{g R S_{f}} \\
\text { Rouse }=\omega / k \mu_{*}
\end{gathered}
$$

onde $k$ é a constante de Von Karman, igual a 0,4. Esse adimensional exprime a razão entre a queda da partícula e a força de turbulência que a mantém em suspensão, sendo que, para Rouse <2,5, prevalece o movimento de suspensão das partículas. Do contrário, o movimento é dominado pelo arrasto de fundo.

No que se refere à erosão do leito, de forma análoga à deposição, pode-se calcular um coeficiente de erosão $\left(C_{e}\right)$, Equação (9), que representa o percentual do déficit de sedimentos, oriundo do cálculo da máxima capacidade de transporte, que efetivamente será convertido em erosão. Trata-se de um coeficiente empírico, proposto por Brunner (2010), baseado em estudos de canais experimentais:

$$
C_{e}=1,368-e^{-(l / 30 Y)}
$$

onde $e$ é o número de Euler e $l$ é o comprimento do volume de controle. Dessa relação, exprime-se que o coeficiente se aproxima de 0,368 à medida que 0 comprimento se aproxima da profundidade. Nesse limite inferior, 36,8 \% do déficit são convertidos em erosão. Apenas em casos onde o comprimento excede em 30 vezes a profundidade é que ocorre conversão de $100 \%$ do déficit em erosão.

Outro processo limitante da erosão é o encouraçamento do leito. Segundo Parker (2008), trata-se de uma camada de material mais grosseiro, sobre a superfície de fundo, que tende a reduzir o transporte total devido à maior energia necessária para mobiliza-la e por impedir o movimento sedimentos mais finos trapeados sob ela.

Hirano (1971) introduziu um modelo simples, sem fatores explícitos de encouraçamento, mas que limita o transporte dividindo o leito em duas camadas, uma ativa, disponível para o transporte, e outra inativa, que não tem qualquer influência no cálculo (Figura 2-3). No caso de erosão, o método limita a degradação do leito à espessura $d_{90} \mathrm{e}$, ao final do incremento, recompõe a camada ativa com material da camada inativa até recuperar essa espessura, replicando a mesma 
distribuição granulométrica em ambas as camadas. No caso de assoreamento, frequentemente são utilizadas as relações empíricas propostas por Toro-Escobar et al. (1996): ao final do incremento de tempo, $70 \%$ do material excedente (depositado) é transferido para a camada inativa e os outros $30 \%$ para a camada ativa. Para manter a espessura limite $d_{90}, 30 \%$ do material original da camada ativa (do início do incremento computacional) são transferidos para a camada inativa.
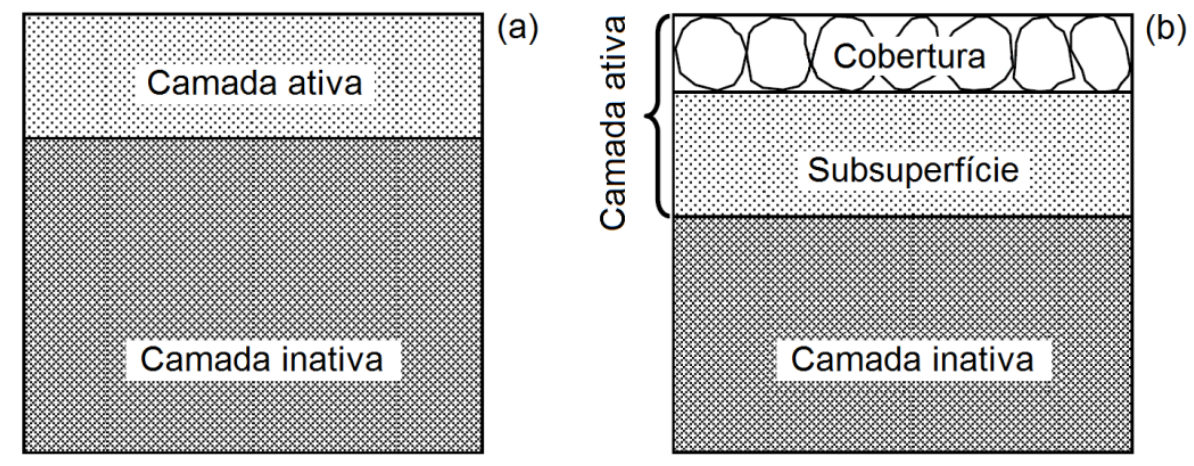

Figura 2-3 - Ilustração esquemática dos métodos de encouraçamento do leito de (a) Hirano e (b) Thomas-Copeland. Fonte: adaptado de Brunner (2010).

De modo a explicitar matematicamente o encouraçamento, Thomas (1982) propôs um método de três camadas (Figura 2-3), posteriormente adaptado por Copeland (1993) para leitos arenosos, que subdivide a camada ativa em duas, uma de cobertura e outra de subsuperfície. Segundo esse método, se os grãos mais finos são transportados mais rapidamente do que os mais grosseiros, a camada de cobertura aumenta, reduzindo o transporte de arrasto. Para tanto, Thomas (1982) introduziu o conceito de espessura equivalente da partícula $\left(d_{e q}\right)$, obtida pela conversão da massa da camada ativa em volume, distribuída ao longo do volume de controle, de onde estima-se a espessura relativa dessa camada para cada classe granulométrica $j$. Copeland (1993) utilizou esse conceito para propor um coeficiente de encouraçamento $\left(C_{e n c}\right)$, Equação (10):

$$
C_{e n c}=-0,026 \times\left(\sum_{j+1}^{M} d_{e q}\right)^{3}+0,28 \times\left(\sum_{j+1}^{M} d_{e q}\right)^{2}-1,07 \times\left(\sum_{j+1}^{M} d_{e q}\right)+1,4
$$

onde $\Sigma d_{e q}$ refere-se ao somatório das espessuras equivalentes a todas as classes 
maiores que a classe $j$ de interesse, restritas à camada ativa.

Esse coeficiente varia entre 0 e 1 e é multiplicado ao déficit da máxima capacidade total de transporte, reduzindo a degradação do leito quando menor que 1. A cada início de incremento computacional, o modelo recria a camada de cobertura do incremento anterior, mantendo o efeito de encouraçamento. A camada de subsuperfície é recomposta limitada a uma espessura máxima da camada ativa equivalente a $2 d_{90}$ ou $0,15 Y$, o que for maior. Durante um incremento, se todo o déficit calculado for suprido com material disponível na camada de cobertura, o coeficiente não é utilizado. Caso contrário, é calculado e aplicado à camada de subsuperfície.

Uma vez que o balanço de massa da Equação de Exner foi solucionado, os coeficientes (de deposição, erosão e encouraçamento) são aplicados e a massa de sedimentos deficitária, ou superavitária, é convertida em volume e subtraída, ou adicionada ao leito, de forma distribuída ao longo de todo o volume de controle, provocando alterações na geometria da seção transversal (Figura 2-4). A massa total que sai do volume de controle, ao longo do tempo, representa a descarga sólida $\left(Q_{S}\right)$.

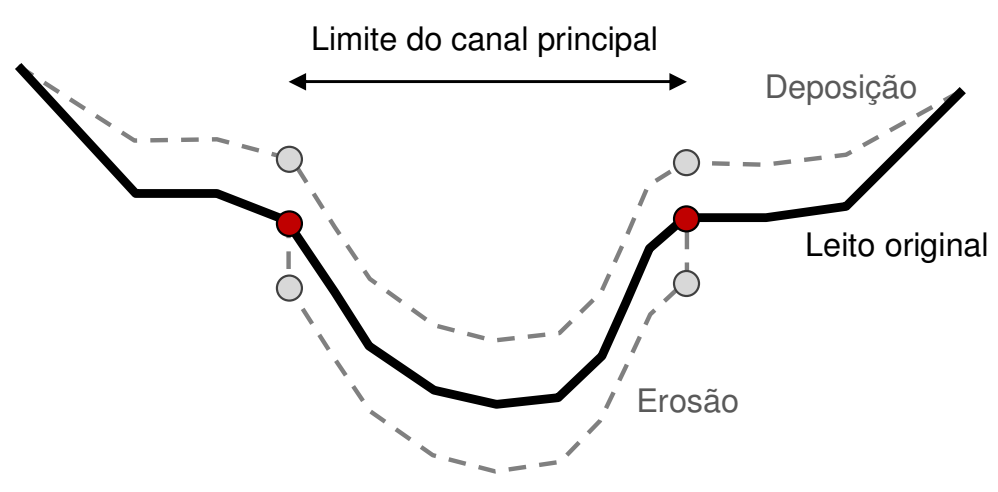

Figura 2-4 - llustração esquemática da erosão e deposição em modelos unidimensionais de transporte de sedimentos. Fonte: adaptado de Brunner (2010).

\subsection{FUNÇÕES DE CAPACIDADE DE TRANSPORTE}

Segundo García (2008), há duas escolas de pensamento que se distinguem no entendimento dos mecanismos que regem a morfodinâmica fluvial, de onde derivaram a grande maioria das funções empíricas de capacidade de transporte de sedimentos utilizadas na engenharia. 
$\mathrm{Na}$ que decorre dos estudos de Bagnold (1956), o transporte de arrasto é definido como sucessivos movimentos das partículas, ora ascendentes, impulsionados pelos vórtices turbulentos do escoamento, ora descendentes, devido ao excesso de força peso da partícula, sendo o movimento global limitado exclusivamente pela força gravitacional. Dessa escola de pensamento originaram-se as funções de transporte total propostas por Ackers e White (1973), baseada em experimentos em um canal com leito formado por areia e cascalho, e Yang (1973, 1984), baseada em dados experimentais e de campo, de sistemas compostos por sedimentos grosseiros, com grande descarga sólida de arrasto.

Por outro lado, Einstein $(1942,1950)$ propôs que o transporte próximo ao leito limita-se a uma fina camada, de aproximadamente $2 d_{90}$, condicionado a movimentos de arrasto, rolamento e saltitação, sendo a influência da turbulência desprezível nessa camada, onde inexistem mecanismos de suspensão. Baseados nessa escola, Engelund e Hansen (1967) desenvolveram sua função de transporte total em canal experimental com leito arenoso e substancial carga de suspensão, Toffaleti (1968) apoiou-se em grande quantidade de dados de sistemas fluviais, com expressiva carga de areia em suspensão, e Copeland e Thomas (1989) adaptaram a função proposta por Laursen (1958), baseando-se em dados experimentais e de campo, de sistemas fluviais com sedimentos na faixa do silte ao cascalho.

Por serem equacionamentos empíricos, deve-se observar a amplitude dos dados de entrada utilizados na calibração do modelo proposto por cada autor. Thomas, Copeland e McComas (2002) compilaram informações úteis (Tabela 2-1), com o intuito de orientar a seleção dessas funções, ainda que os limites de aplicabilidade apresentados não se constituam de barreira rígida, devendo cada função ser avaliada frente às características hidráulicas e sedimentológicas observadas no sistema fluvial de interesse.

Além disso, segundo Brunner (2016), a maioria das funções de capacidade de transporte foi desenvolvida com dados de sistemas compostos por sedimentos não coesivos, sendo que sua aplicação em sistemas com predomínio de sedimentos finos (argila e silte) pode resultar na superestimação do transporte de suspensão.

A seguir, será detalhado o desenvolvimento das funções de LaursenCopeland e Toffaleti, devido à sua aderência à área de estudo, conforme os resultados que serão apresentados no item 5.4 e discutidos em 6.2. 
Tabela 2-1 - Limites de aplicabilidade de algumas das principais funções de capacidade de transporte de sedimentos. Fonte: adaptado de Thomas, Copeland e McComas (2002)

\begin{tabular}{lcccccc}
\hline Função & $\boldsymbol{d}(\mathbf{m m})$ & $\boldsymbol{V}(\mathbf{m} / \mathbf{s})$ & $\boldsymbol{Y}(\mathbf{m})$ & $\boldsymbol{S}_{\mathbf{0}}(\mathbf{m} / \mathbf{m})$ & $\boldsymbol{B}(\mathbf{m})$ & $\boldsymbol{T}\left(\mathbf{O}^{\circ} \mathbf{C}\right)$ \\
\hline Ackers-White & $0,04-7$ & $0,02-2,2$ & $0,003-0,4$ & $0,00006-0,037$ & $0,07-1,2$ & $7,8-31,7$ \\
Engelund-Hansen & $0,19-0,93$ & $0,2-1,9$ & $0,06-0,4$ & $0,000055-0,019$ & $\mathrm{ND}^{* *}$ & $7,2-33,9$ \\
Laursen-Copeland & $0,011-29$ & $0,02-2,9$ & $0,009-16,5$ & $0,0000021-0,025$ & $0,08-1109,5$ & $0-33,9$ \\
Toffaleti & $0,062-4$ & $0,2-2,4$ & $0,02-17,3^{*}$ & $0,000002-0,019$ & $0,24-1109,5$ & $0-33,9$ \\
Yang & $0,15-7$ & $0,24-2$ & $0,01-15,2$ & $0,000043-0,029$ & $0,13-533,4$ & $0-34,4$ \\
\hline
\end{tabular}

* o autor apresenta essa variável como Raio Hidráulico

** não disponível

\subsubsection{Laursen-Copeland}

Copeland e Thomas (1989), em sua adaptação da função proposta por Laursen (1958), consideraram que a tensão de cisalhamento crítica $\left(\tau_{c}\right)$, parâmetro relacionado ao início do movimento de arrasto, varia com o diâmetro da partícula, sendo que grãos mais grosseiros possuem maior tensão de cisalhamento crítica. Copeland e Thomas (1989) propuseram que para números de Shields, Equação (11), maiores que 0,05 , a tensão de cisalhamento crítica é igual a 0,039 , caso contrário, 0,020:

$$
\tau_{0}^{*}=\frac{\tau_{0}}{\left(\gamma_{s}-\gamma_{a}\right) d_{j}}
$$

onde $\tau_{0}^{*}$ é o número de Shields, $\gamma_{s}$ é o peso específico do sedimento, $\gamma_{a}$ é o peso específico da água, $d_{j}$ é a média geométrica dos diâmetros da classe granulométrica $j$ e $\tau_{0}$ é a tensão de cisalhamento efetiva, Equação (12):

$$
\tau_{0}=\gamma_{a} R S_{f}
$$

Essa abordagem implica que o início do movimento, para partículas mais grosseiras, ocorre sob tensões de cisalhamento menores, aumentando o potencial de transporte.

Para o cálculo da tensão de cisalhamento do grão, Equação (13), Copeland e Thomas (1989) adotam o raio hidráulico em função do coeficiente $n$ de Manning $\left(R^{\prime}\right)$, 
conforme proposto Limerinos (1970), Equação (14):

$$
\begin{gathered}
\tau_{0}^{\prime}=\frac{\rho V^{2}}{58}\left(\frac{d_{50}}{R^{\prime}}\right)^{1 / 3} \\
n=\frac{0,0926 R^{\prime 1 / 6}}{1,16+2 \log \left(\frac{R^{\prime}}{d_{84}}\right)}
\end{gathered}
$$

onde $\tau_{0}^{\prime}$ é a tensão de cisalhamento do grão, $\rho$ é a massa específica da água, $V$ é velocidade média do escoamento e $d_{50}$ e $d_{84}$ são os diâmetros característicos relacionados à frequência de $50 \%$ e $84 \%$, respectivamente.

Do ponto de vista do transporte em suspensão, foi incorporada uma nova relação adimensional entre a velocidade de atrito e a velocidade de queda do grão $\left(u_{*} / \omega\right)$, sobrepondo-se àquela proposta na função original, sendo considerada teoricamente mais consistente por basear-se em uma maior variedade de dados físicos de campo e experimentais (Figura 2-5).

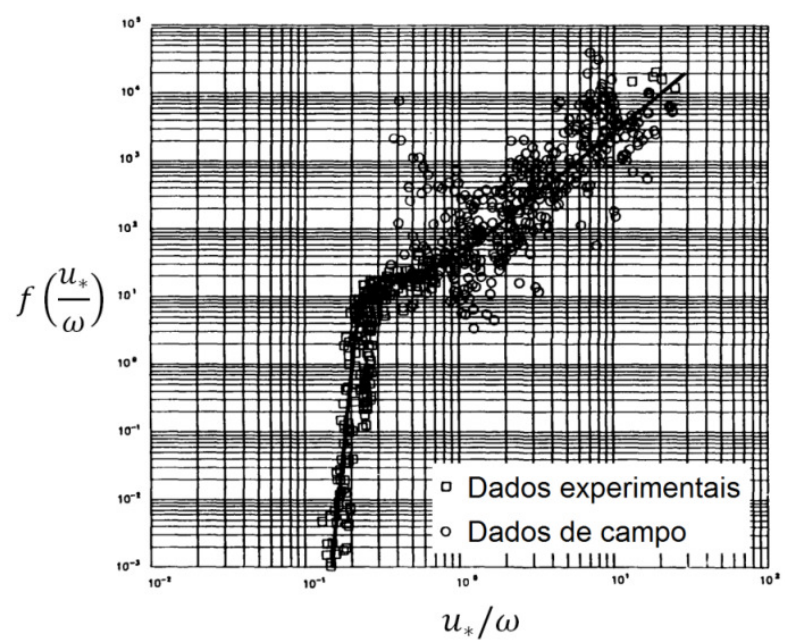

Figura 2-5 - Relação entre velocidade de atrito e velocidade de queda da função de LaursenCopeland. Fonte: Copeland e Thomas (1989).

A partir desses critérios, a concentração de sedimentos total (CST) é calculada pela Equação (15), sendo a descarga sólida a multiplicação da CST pela vazão na seção de interesse, para cada classe granulométrica $j$ : 


$$
C S T=0,01 \gamma_{a} \sum_{j}\left[\eta_{j}\left(\frac{d_{j}}{Y}\right)^{7 / 6}\left(\frac{\tau_{0}^{\prime}}{\tau_{c, j}}-1\right) f\left(\frac{u_{*}}{\omega_{j}}\right)\right]
$$

\subsubsection{Toffaleti}

Toffaleti (1968) propôs um procedimento para determinação analítica do transporte de areia adaptando os conceitos de Einstein, em uma abordagem relativamente mais simples. Contudo, diferentemente desse, observou que a correlação entre a tensão de cisalhamento e a intensidade do transporte não se limita ao transporte de arrasto, na faixa equivalente a $2 d_{90}$. Toffaleti (1968) estendeu essa relação para toda a coluna vertical, propondo equações de transporte por zona (Figura 2-6), discretizadas de acordo com as melhores correlações encontradas entre descarga sólida e incremento vertical.

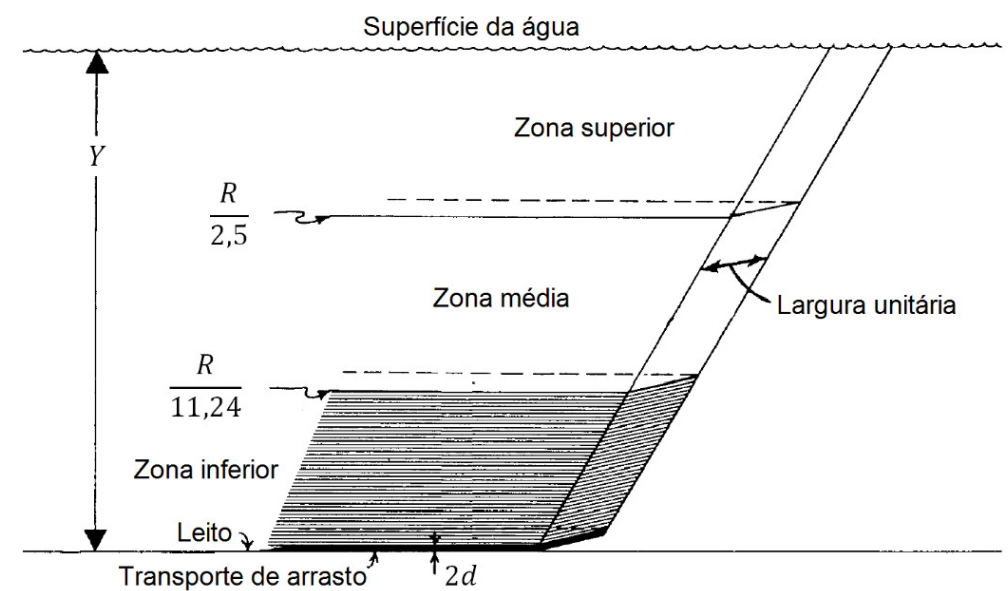

Figura 2-6 - llustração esquemática da discretização vertical da função de Toffaleti. Fonte: adaptado de Toffaleti (1968).

As equações gerais ${ }^{3}$ que descrevem o transporte em cada zona, para uma determinada faixa granulométrica, são apresentadas nas Equações (16) a (20), sendo $q_{b}$ a descarga sólida de arrasto unitária, $q_{s s Z I}$ a descarga sólida unitária em suspensão na zona inferior, $q_{s s z M}$ na zona média, $q_{s s z s}$ na zona superior, e $Q_{s}$ a descarga sólida total:

${ }^{3}$ As equações são apresentadas em sua forma funcional, segundo Brunner (2010) e os coeficientes das equações são compatíveis com o Sistema Inglês de medidas. 


$$
\begin{aligned}
& q_{b}=W\left(2 d_{m}\right)^{1+n_{V}-0,756 z} \\
& q_{S S Z I}=W \frac{\left(\frac{R}{11,24}\right)^{1+n_{V}-0,756 z}-\left(2 d_{m}\right)^{1+n_{V}-0,756 z}}{1+n_{V}-0,756 z} \\
& q_{S S Z M}=W \frac{\left(\frac{R}{11,24}\right)^{0,244 z}\left[\left(\frac{R}{2,5}\right)^{1+n_{V}-z}-\left(\frac{R}{11,24}\right)^{1+n_{V}-z}\right]}{1+n_{V}-z} \\
& q_{s S ~ Z S}=W \frac{\left(\frac{R}{11,24}\right)^{0,244 z}\left(\frac{R}{2,5}\right)^{0,5 z}\left[R^{1+n_{V}-1,5 z}-\left(\frac{R}{2,5}\right)^{1+n_{V}-1,5 z}\right]}{1+n_{V}-1,5 z} \\
& Q_{s}=\left(q_{b}+q_{s s Z I}+q_{s s Z M}+q_{s s Z S}\right) B
\end{aligned}
$$

onde $d_{m}$ é o diâmetro mediano da faixa granulométrica de interesse, $n_{V}$ é o coeficiente de temperatura, Equação (21), z é o coeficiente que descreve a relação entre o sedimento e as características hidráulicas da seção, Equação (22), e $W$ é o coeficiente de concentração de sedimentos, Equação (23):

$$
\begin{gathered}
n_{V}=0,1198+0,00048 T \\
z=\omega V /(260,67-0,667 T) R S_{f} \\
W=43,2 W_{Z I}\left(1+n_{V}\right) V R^{0,756 z-n_{V}}
\end{gathered}
$$

onde $T$ é a temperatura, $\omega$ é a velocidade de queda do grão segundo relações empíricas do próprio autor (disponível em ábacos no manuscrito original) e $W_{Z I}$ é o coeficiente relacionado à concentração de sedimentos na zona inferior, Equação (24):

$$
W_{Z I}=100 /\left(\frac{2 d_{m}}{R}\right)^{-0,756 z}
$$




\section{3 ÁREA DE ESTUdO}

\subsection{GENERALIDADES E ANTECEDENTES HISTÓRICOS}

O reservatório Taiaçupeba localiza-se na Unidade de Gerenciamento de Recursos Hídricos do Alto Tietê, na divisa dos municípios de Suzano e Mogi das Cruzes, São Paulo, Brasil. Seu barramento foi construído na planície do rio Taiaçupeba Açu, afluente da margem esquerda do rio Tietê, formado por três tributários principais, os rios Taiaçupeba Mirim, Balainho e Taiaçupeba Guaçu, perfazendo uma área de drenagem de $224 \mathrm{~km}^{2}$ (Figura 3-1).

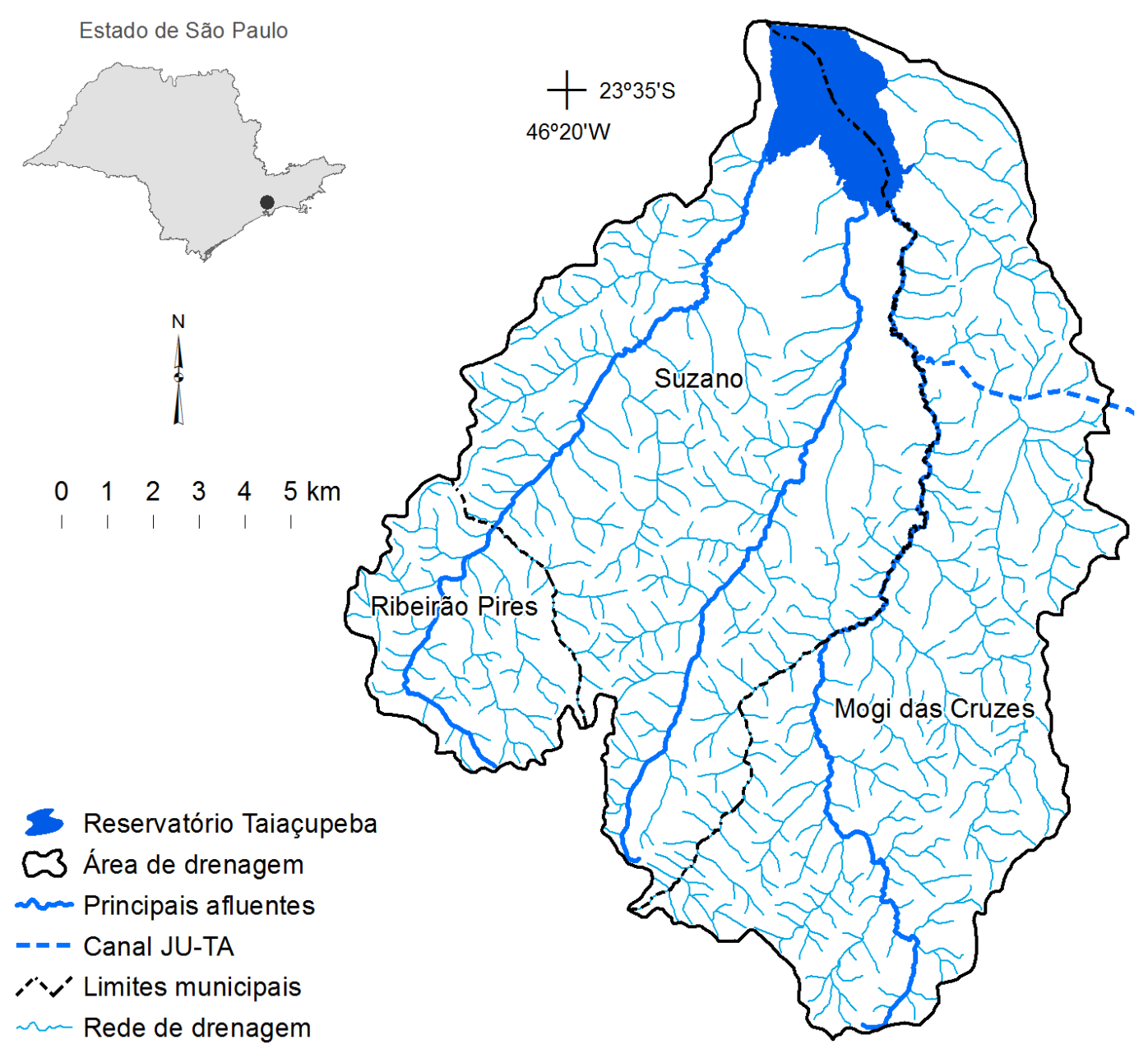

Figura 3-1 - Localização da área de estudo. De oeste para leste, os principais afluentes são os rios Taiaçupeba Mirim, Balainho e Taiaçupeba Guaçu. No extremo leste, o canal de transferência JU-TA, afluente do rio Taiaçupeba Guaçu. 
Segundo o Serviço do Vale do Tietê (1969), as nascentes desses cursos d'água cortam terrenos de declividade relativamente acentuada, na face interior da Serra do Mar, mas logo atingem seu nível de base, apresentando um baixo curso sinuoso, atravessando extensas planícies aluviais. Seu regime fluvial apresenta os mesmos aspectos dos rios de planalto da região Centro-Sul, com estiagem entre os meses de julho e setembro e cheias entre dezembro e fevereiro.

Ainda segundo o Serviço do Vale do Tietê (1969), a barragem do rio Taiaçupeba Açu foi uma obra necessária em virtude de sua proximidade com 0 município de São Paulo, da extensão de sua bacia e dos altos índices pluviométricos em suas nascentes, sujeitas ao efeito orográfico da Serra do Mar, exercendo notável influência nas enchentes do rio Tietê na capital paulista. A vazão de regularização prevista para a obra foi de $3,9 \mathrm{~m}^{3} / \mathrm{s}$, para a qual foi necessário projetar um reservatório com volume ${ }^{4}$ útil de $87,9 \mathrm{hm}^{3}$, com a soleira do vertedor na cota $747,00 \mathrm{~m}$, nível máximo maximorum na cota $749,60 \mathrm{~m}$, borda livre de 1,90 m e crista da barragem na cota $751,50 \mathrm{~m}$. Por razões sanitárias e estéticas, foi definida a cota 739,00 m para o nível mínimo, o que correspondeu a um volume morto de 10,6 hm³. As obras foram finalizadas no ano de 1976, quando se iniciou a operação do reservatório.

Contudo, segundo o Departamento de Águas e Energia Elétrica (2015), com o crescimento da metrópole, na década de 1980, houve a necessidade de utilizar o reservatório como manancial de abastecimento público, impondo uma segunda demanda na gestão do recurso hídrico. Foi então concebido o Sistema Produtor do Alto Tietê (Figura 3-2), interligando os cinco reservatórios de regularização de cheias das cabeceiras do rio Tietê por meio de estações elevatórias e canais artificiais de transferência. No ano de 1992 foram finalizadas as obras da Estação de Tratamento de Água Taiaçupeba, localizada na margem esquerda do reservatório, capaz de tratar $15 \mathrm{~m}$ 3/s de água bruta para abastecimento de 5 milhões de pessoas da Zona Leste da Região Metropolitana de São Paulo. Desde então, o sistema é gerenciado pela Sabesp.

\footnotetext{
${ }^{4}$ Os volumes são apresentados em $\mathrm{hm}^{3}$, ou hectômetro cúbico, equivalente a $10^{6} \mathrm{~m}^{3}$.
} 


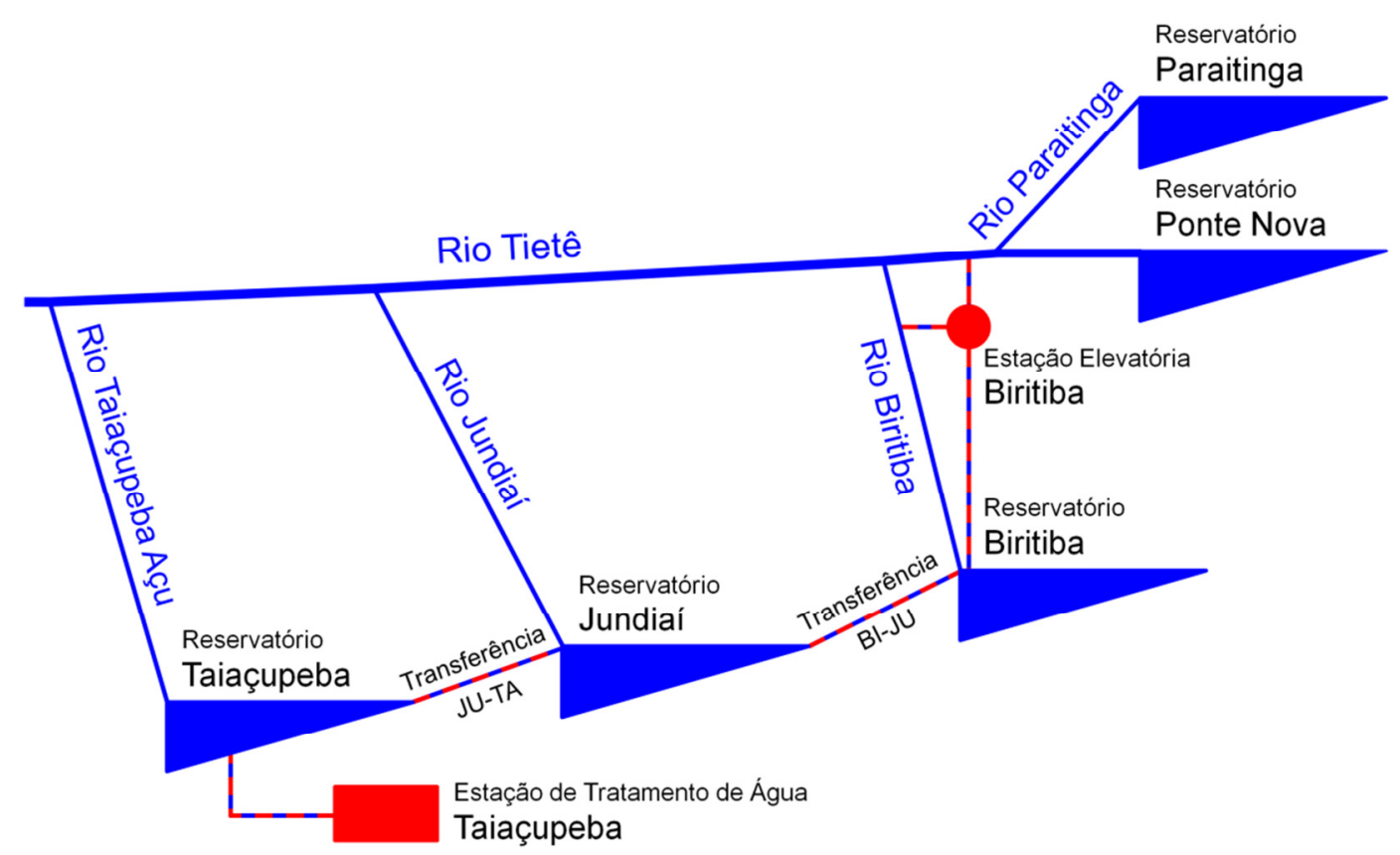

Figura 3-2 - Desenho esquemático do Sistema Produtor do Alto Tietê. Adaptado de Departamento de Águas e Energia Elétrica (2015).

Entre os reservatórios Jundiaí e Taiaçupeba foi construído o canal JU-TA, atravessando o antigo curso do rio Doce, afluente da margem direita do rio Taiaçupeba Guaçu, transpondo o divisor Leste da bacia por um túnel escavado em rocha. Há que se considerar que essa transposição também contribuiu com o aumento na descarga sólida ao sistema fluvial Taiaçupeba.

Em virtude do licenciamento ambiental das obras da barragem de Taiaçupeba, até 14 de novembro de 2016 o nível operacional do reservatório não havia ultrapassado a cota 743,50 m, para a qual o volume útil é de 33,6 hm³ $^{3}(38 \%$ do volume útil de projeto). A partir dessa data, em função do atendimento de exigências do licenciamento ambiental por parte do gestor, o reservatório passou a operar com cota máxima $744,67 \mathrm{~m}$, que corresponde a um volume útil de $47,7 \mathrm{hm}^{3}$ (54\% do volume útil de projeto).

Costa, Souza e Demarco (2017) executaram levantamentos batimétricos no reservatório Taiaçupeba e os compararam à curva cota-volume de projeto, de 1976, oriunda de levantamentos aerofotogramétricos, concluindo que houve uma perda de volume total da ordem de $5 \mathrm{hm}^{3}$ por assoreamento (Figura 3-3), o que corresponde a uma perda de aproximadamente $5 \%$ do volume total de projeto. Importante salientar que o assoreamento compromete tanto a função de retenção de cheias, quanto de abastecimento público, a que se destina o reservatório. 


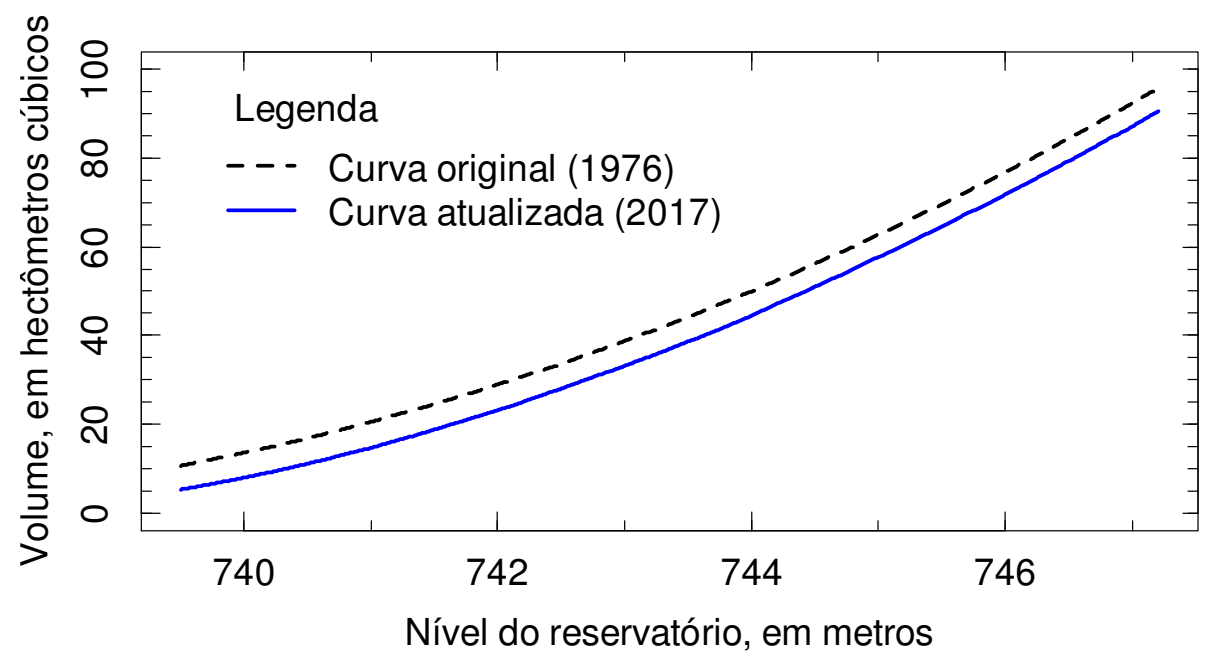

Figura 3-3 - Curvas cota-volume (1976 e 2017) do reservatório Taiaçupeba. Fonte: Costa, Souza e Demarco (2017).

A chuva é a principal fonte de erosão e transporte de sedimentos na bacia, uma condição típica de clima tropical, sendo a precipitação anual da ordem de $1.500 \mathrm{~mm}$. No entanto, durante o período de coleta de dados da pesquisa, entre 2013 e 2015, a Região Metropolitana de São Paulo enfrentou uma estiagem histórica, causada por um sistema de alta pressão anômalo que bloqueou o fluxo de umidade da Amazônia para a Zona de Convergência do Atlântico Sul, responsável pelas chuvas na área durante o verão, conforme exposto por Marengo et al. (2015).

Por consequência, o nível do reservatório Taiaçupeba reduziu drasticamente nesse período, chegando a registrar-se na cota 740,28 m em 01 de novembro 2014, para a qual o volume útil é de $15,4 \mathrm{hm}^{3}$ (18\% do volume útil de projeto). Os níveis típicos de operação foram recuperados somente após dezembro de 2015. Ao longo da dissertação, será discutido como esta condição incomum de seca influenciou a caracterização do regime de transporte de sedimentos.

\subsection{CARACTERÍSTICAS DO SOLO E DA OCUPAÇÃO}

O Instituto de Pesquisas Tecnológicas (2007) avaliou o potencial das terras da bacia do Taiaçupeba à produção de sedimentos (Figura 3-4). Esse estudo, cujo objetivo foi elaborar diretrizes para controle de erosão, compartimentou a área em classes de potencialidade, pela integração do uso e ocupação do solo e da suscetibilidade natural à erosão, conforme descrito a seguir:

- baixa potencialidade à produção de sedimentos: referem-se a terras de 
baixa suscetibilidade natural aos processos erosivos, com predomínio de Latossolos Vermelho-Amarelos (solos minerais em avançado estágio de intemperização, derivados de migmatitos, granitos e xistos) e Cambissolos Háplicos (solos minerais pouco evoluídos, geralmente rasos a pouco profundos, derivados de migmatitos, granitos e xistos), ambos de textura argilosa, em relevo ondulado (declividades entre $3 \%$ e $20 \%$ ), mas cultivadas em regime de sequeiro com culturas anuais e perenes ou com cobertura vegetal, oferecendo proteção ao solo contra processos erosivos; referem-se também a terras praticamente livres de erosão, associadas a Organossolos Mésicos ou Háplicos + Gleissolos Melânicos ou Háplicos (solos hidromórficos derivados de processos deposicionais com sedimentação de finos por decantação, durante as enchentes, e de areias ao longo dos canais), ambos de textura argilosa a média, em relevo plano de várzea ou quase plano (declividades entre $0 \%$ e $3 \%$ );

- média potencialidade: são terras de moderada suscetibilidade natural aos processos erosivos, com predomínio de Latossolos Vermelho-Amarelos e Cambissolos Háplicos, em relevo ondulado a acentuado (declividades entre $6 \%$ e $20 \%$ ), ocupadas por culturas perenes, pastagens e reflorestamentos;

- alta potencialidade: referem-se a terras de alta suscetibilidade natural aos processos erosivos, erodidas, pedregosas ou com solos muito rasos e deficientes de água, com predomínio de Cambissolos Háplicos e Argissolos Vermelho-Amarelos, solos com evidente incremento no teor de argila, do horizonte A para o B textural, de profundidade variável, derivados de migmatitos, granitos e xistos, com textura que varia de arenosa e média no horizonte $A$ até média e argilosa no horizonte $B$ textural, em relevo acentuado (declividades entre $6 \%$ e $50 \%$ ), ocupadas com culturas anuais e reflorestamentos;

- muito alta potencialidade: são terras de muito alta suscetibilidade natural aos processos erosivos, erodidas, pedregosas ou com solos muito rasos (Cambissolos Háplicos e Argissolos Vermelho-Amarelos), ou ainda com deficiência de água muito grande, em relevo fortemente inclinado (declividades superiores a $50 \%$ ), deflúvios muito rápidos, ocupadas por áreas urbanas não consolidadas ou com presença de solo exposto. 

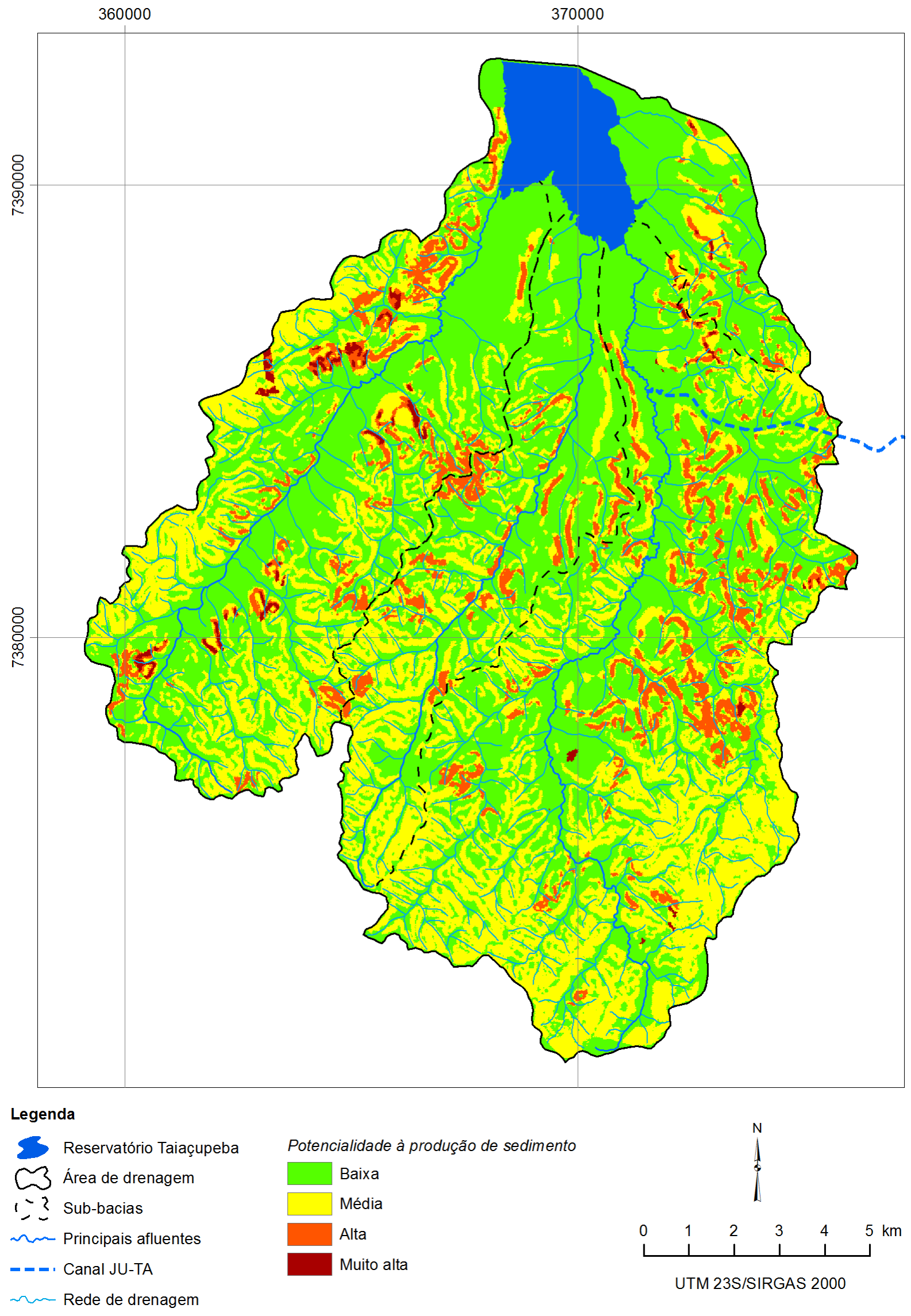

Figura 3-4 - Classes de potencialidade das terras à produção de sedimentos. Fonte: adaptado de Instituto de Pesquisas Tecnológicas (2007). 
Importante destacar que, às classes de média a muito alta potencialidade à produção de sedimentos, associam-se solos de textura argilosa (Latossolos Vermelho-Amarelos e Cambissolos Háplicos), com teor de argila entre $35 \%$ e $60 \%$, e de textura arenosa e média a média e argilosa (Argissolos Vermelho-Amarelos com horizonte B textural), com teor de argila entre $10 \%$ e $60 \%$. Assim, é esperado que a carga de lavagem produzida na bacia seja composta, predominantemente, por material de granulometria fina, com diâmetro inferior a 0,0625 mm.

Nas cabeceiras da bacia, o solo é ocupado por vegetação nativa, enquanto culturas de hortaliças são predominantes nas porções média e baixa. Aglomerados urbanos espalham-se ao longo do rio Taiaçupeba Mirim. A Leste do reservatório, pequenas minerações de caulim são encontradas. Em termos de evolução do uso do solo, não foram observadas mudanças substanciais no padrão de ocupação nas últimas quatro décadas. Pela comparação das assinaturas espectrais entre imagens orbitais de 1975 e 2017 (Figura 3-5), os usos antrópicos avançaram de 23 \% para 27 \% da área da bacia, em decorrência da redução do percentual ocupado por vegetação, de $77 \%$ para $73 \%$. Desse modo, o regime de transporte de sedimentos foi considerado inalterado no período, para fins de simplificação do modelo.
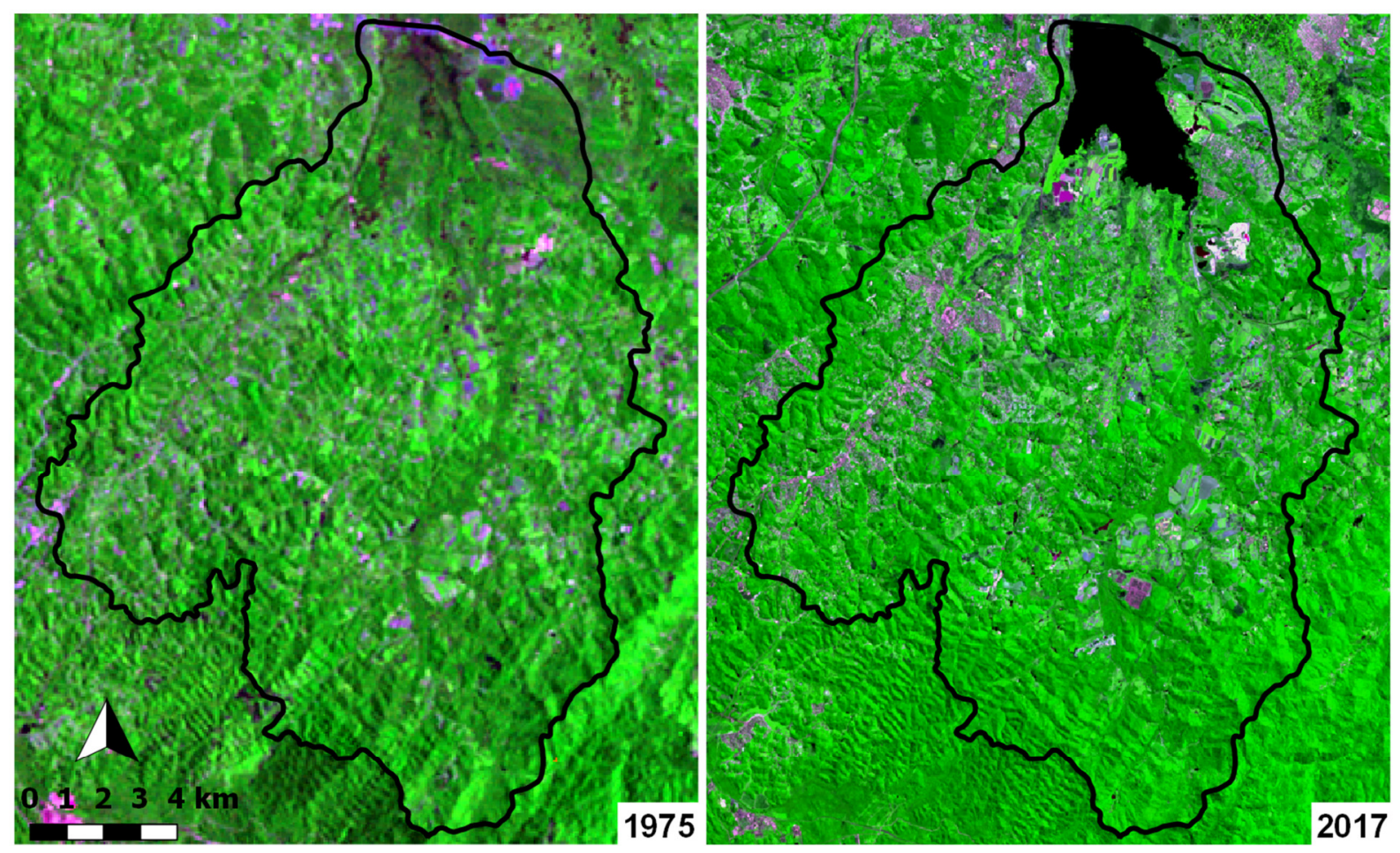

Figura 3-5 - Comparação de imagens dos satélites Landsat 1-5 MSS (resolução espacial de $60 \mathrm{~m}$ ), de 1975, e Landsat 8 OLI (resolução espacial de $30 \mathrm{~m}$ ), de 2017, para a área de drenagem do reservatório Taiaçupeba (linha sólida preta). Fonte das imagens: https://earthexplorer.usgs.gov/. 


\subsection{REDE FLUVIOMÉTRICA}

Não houve monitoramento contínuo dos tributários do reservatório ao longo de sua operação. O Departamento de Águas e Energia Elétrica do Estado de São Paulo (DAEE) operou, entre 1960 e 1976, três postos fluviométricos (Figura 3-6), com medições diárias de nível d'água e vazão estimada por curva de descarga, cujos dados subsidiaram o projeto da barragem. Esses postos foram descontinuados após o enchimento do reservatório. Entre 2003 e 2007, o Instituto de Pesquisas Tecnológicas operou cinco postos fluvissedimentométricos, com periodicidade de medição quinzenal, para o desenvolvimento de estudos de controle de erosão. A partir de 2009, a Sabesp iniciou leituras manuais de réguas limnimétricas e medições de vazão mensais, em três postos, para fins de controle de operação do reservatório.

O monitoramento telemétrico na área foi iniciado apenas em 2013, com a instalação do posto fluviométrico AT-10c, no canal JU-TA, para medição das vazões de transferência do reservatório Jundiaí. Em 2015 foi iniciada a operação do posto AT-27, no rio Taiaçupeba Mirim, para monitorar as vazões transferidas do reservatório Billings (braço do rio Grande) e, em 2016, o posto AT-30, no ribeirão dos Moraes, para monitorar as vazões transferidas do rio Guaió, ambas obras emergenciais executadas para contornar os problemas da estiagem (SABESP, 2015). Esses três postos são operados pela Fundação Centro Tecnológico de Hidráulica. 

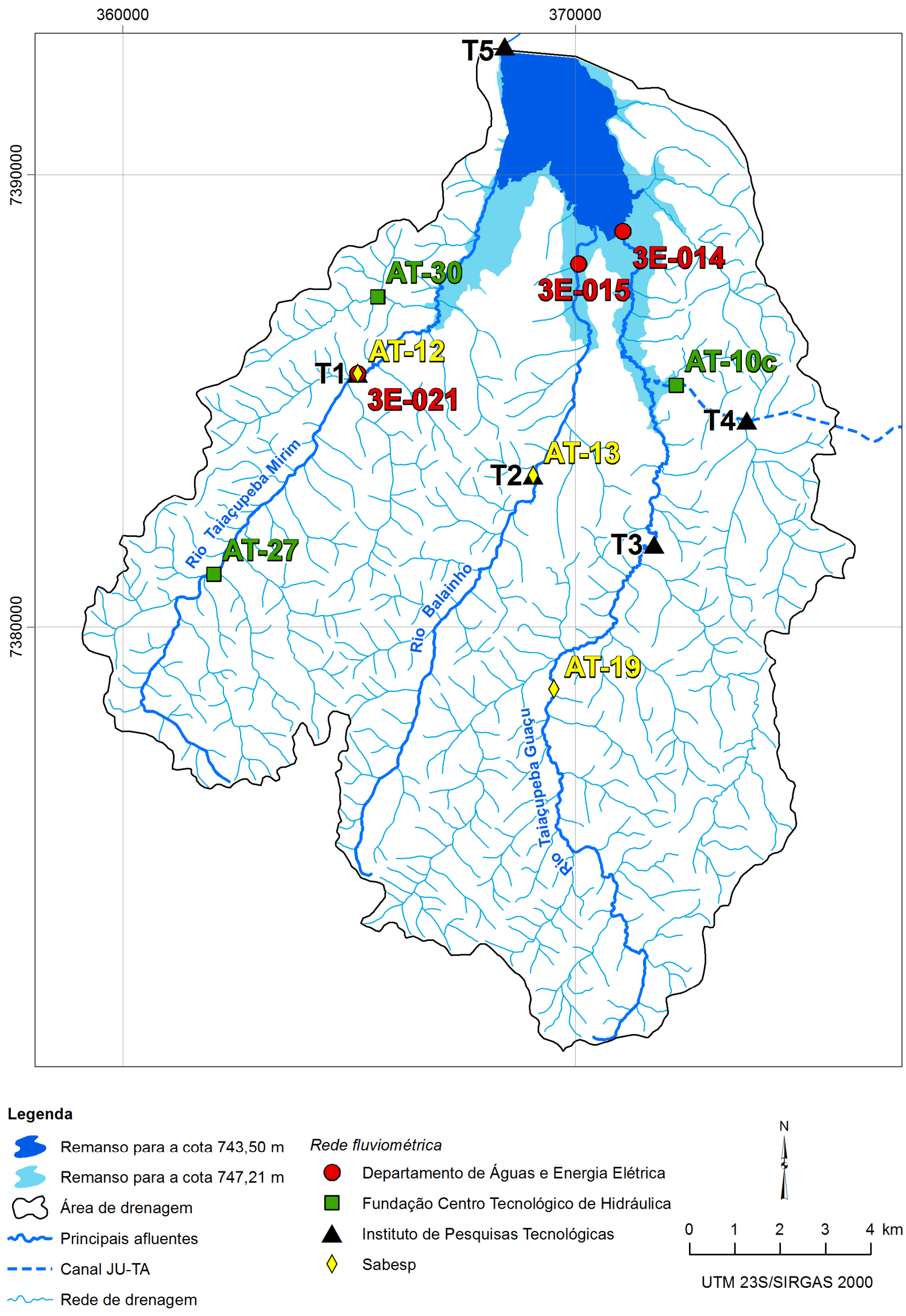

Rede fluviométrica

Departamento de Águas e Energia Elétrica

$\square$ Fundação Centro Tecnológico de Hidráulica

- Instituto de Pesquisas Tecnológicas

$\diamond$ Sabesp

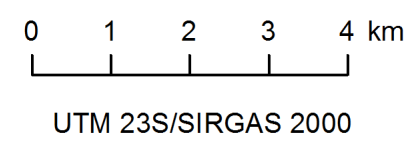

Figura 3-6 - Postos da rede fluviométrica na área de drenagem do reservatório Taiaçupeba. 


\section{MÉTODO}

\subsection{AMOSTRAGEM DE SEDIMENTOS}

Os postos fluvissedimentométricos (Figura 4-1 a Figura 4-5 e Tabela 4-1) foram definidos nos mesmos locais da rede secundária criada pelo Instituto de Pesquisas Tecnológicas (2007), de modo que pelo menos $80 \%$ da área de drenagem fosse monitorada, abrangendo tributários importantes, que respondem por mais de $10 \%$ da descarga total afluente, o mais próximo possível do reservatório, a montante do remanso, segundo recomendações de Carvalho (2008). Foi também selecionado um posto a jusante do barramento, no canal extravasor da tomada d'água TA-2, a fim de estimar a descarga sólida defluente média.

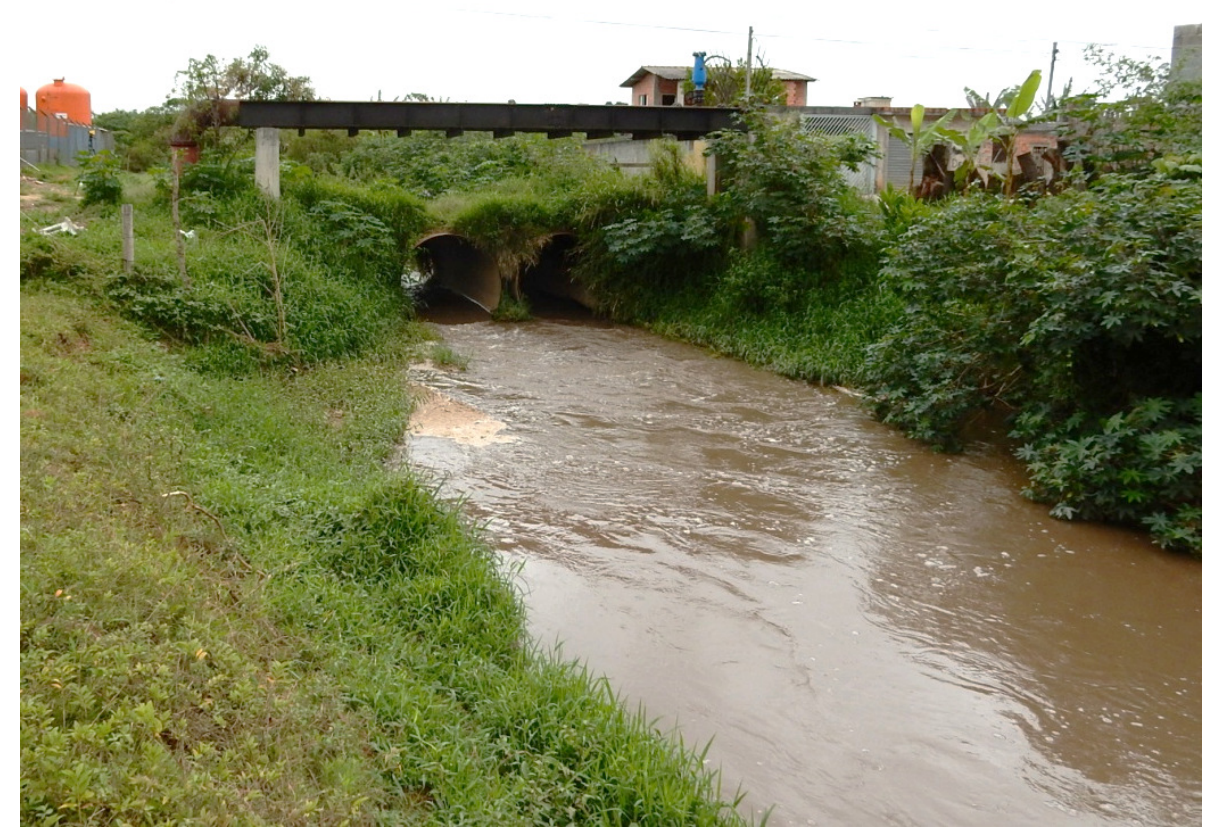

Figura 4-1 - Posto fluvissedimentométrico T1, no rio Taiaçupeba Mirim. 


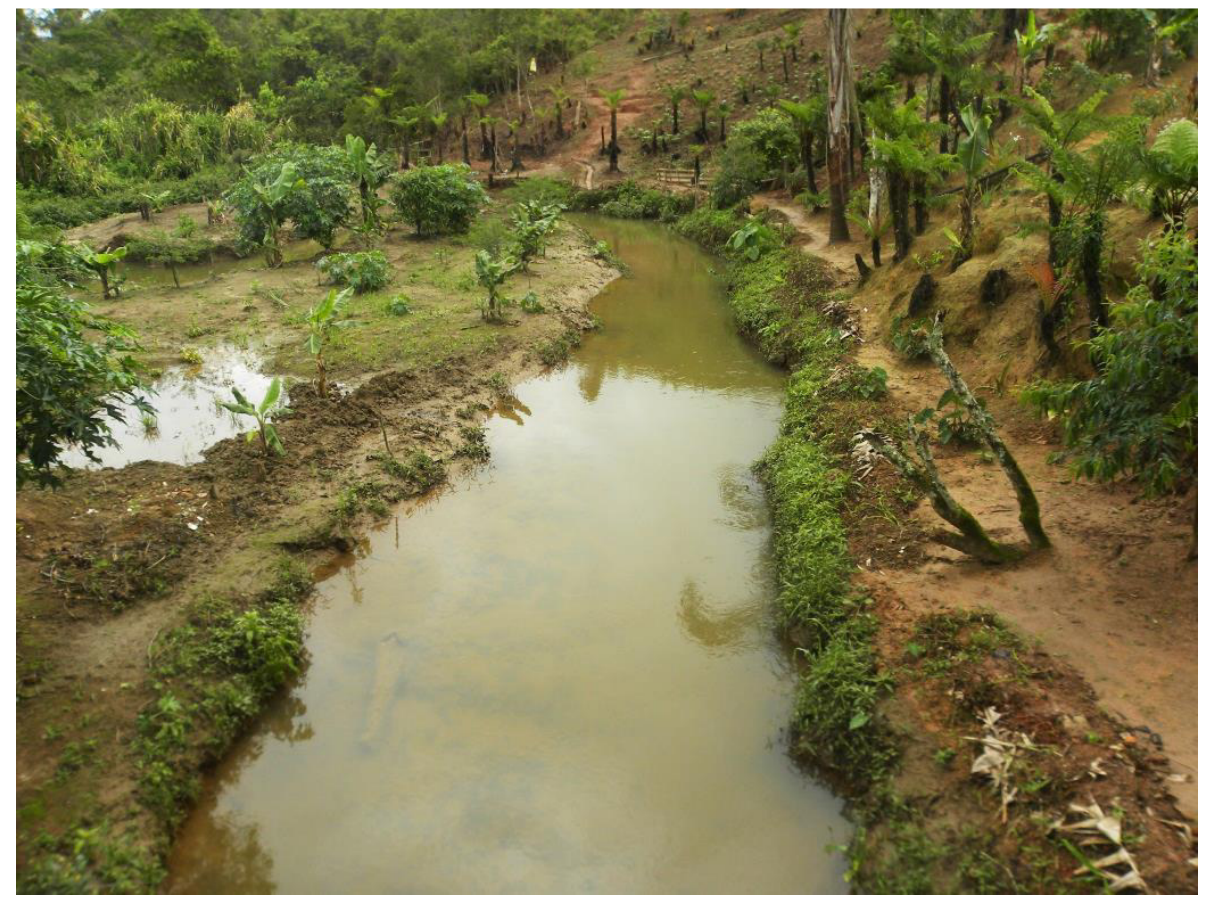

Figura 4-2 - Posto fluvissedimentométrico T2, no rio Balainho.

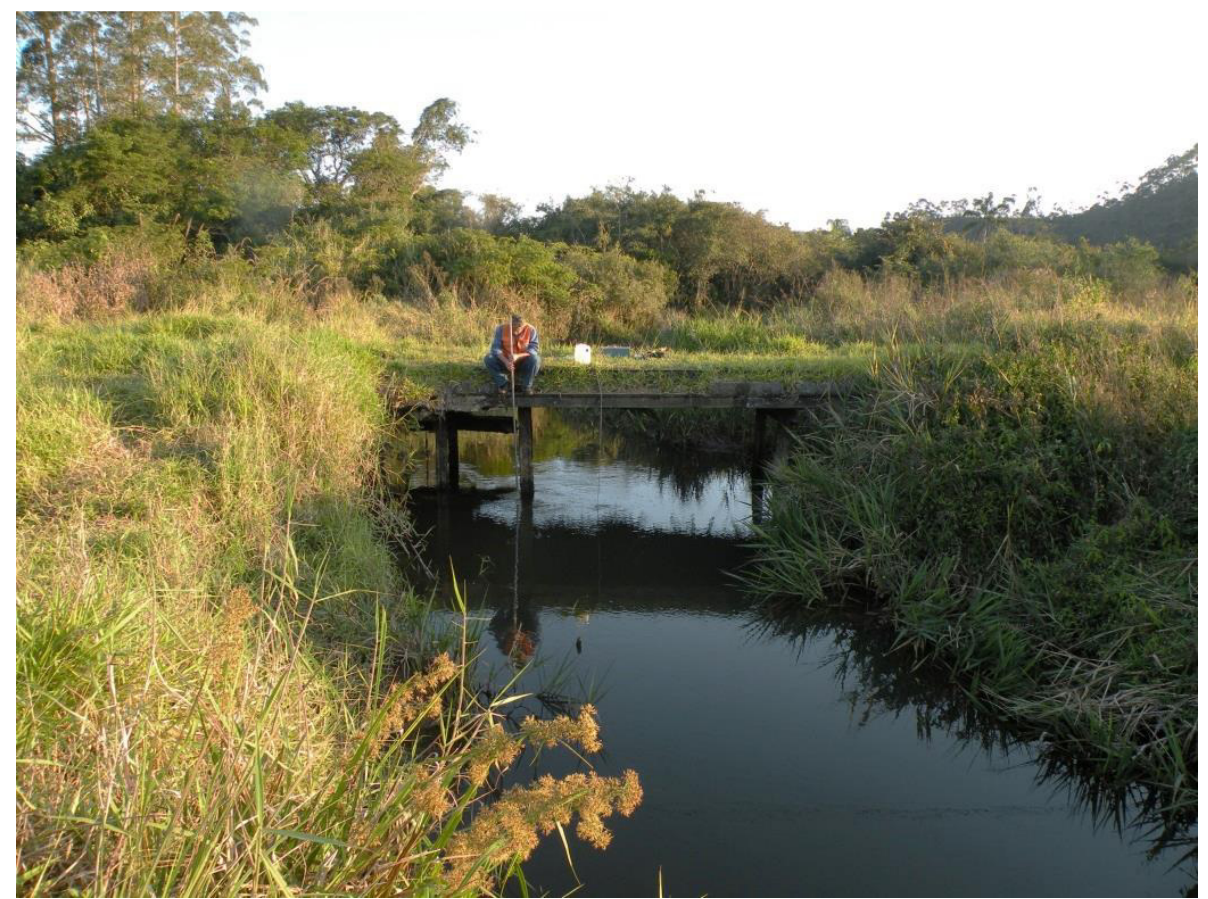

Figura 4-3 - Posto fluvissedimentométrico T3, no rio Taiaçupeba Guaçu. 


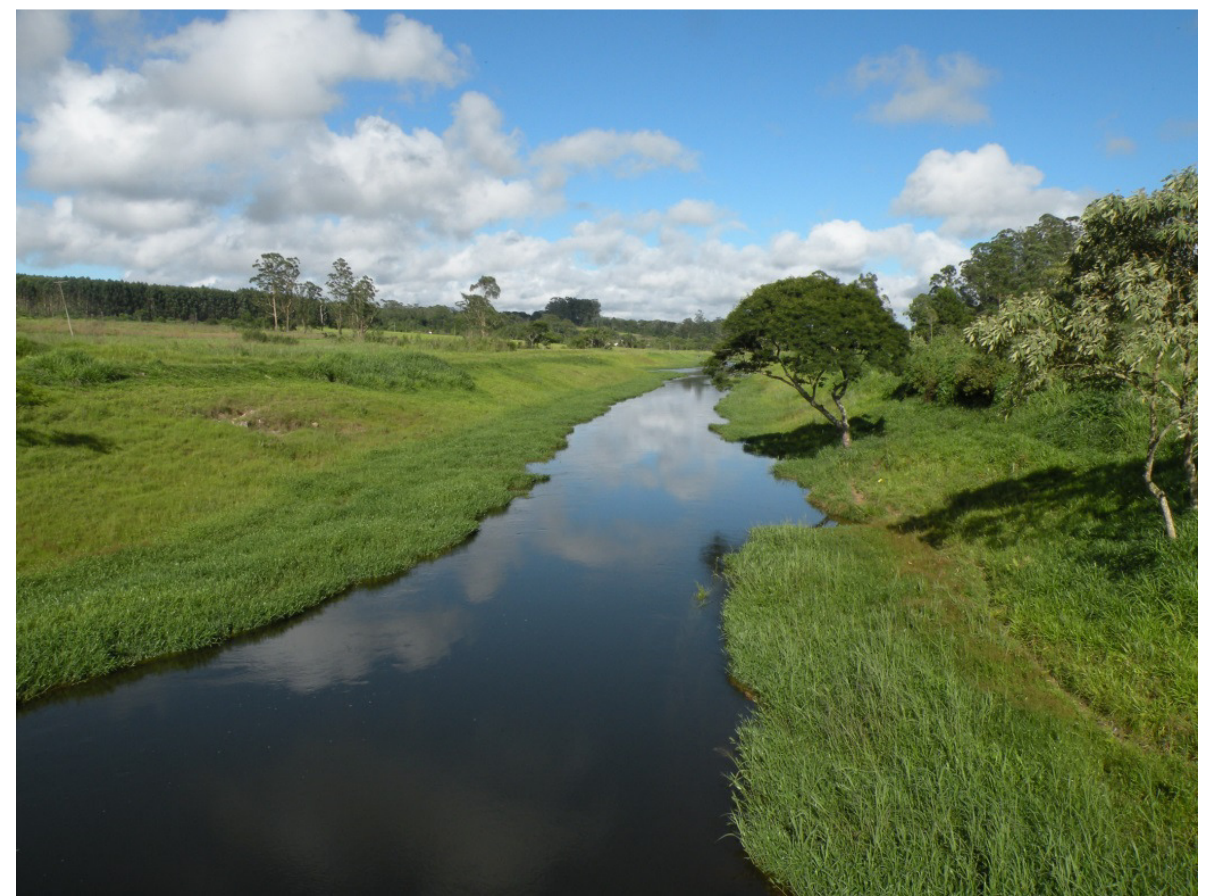

Figura 4-4 - Posto fluvissedimentométrico T4, no canal JU-TA.

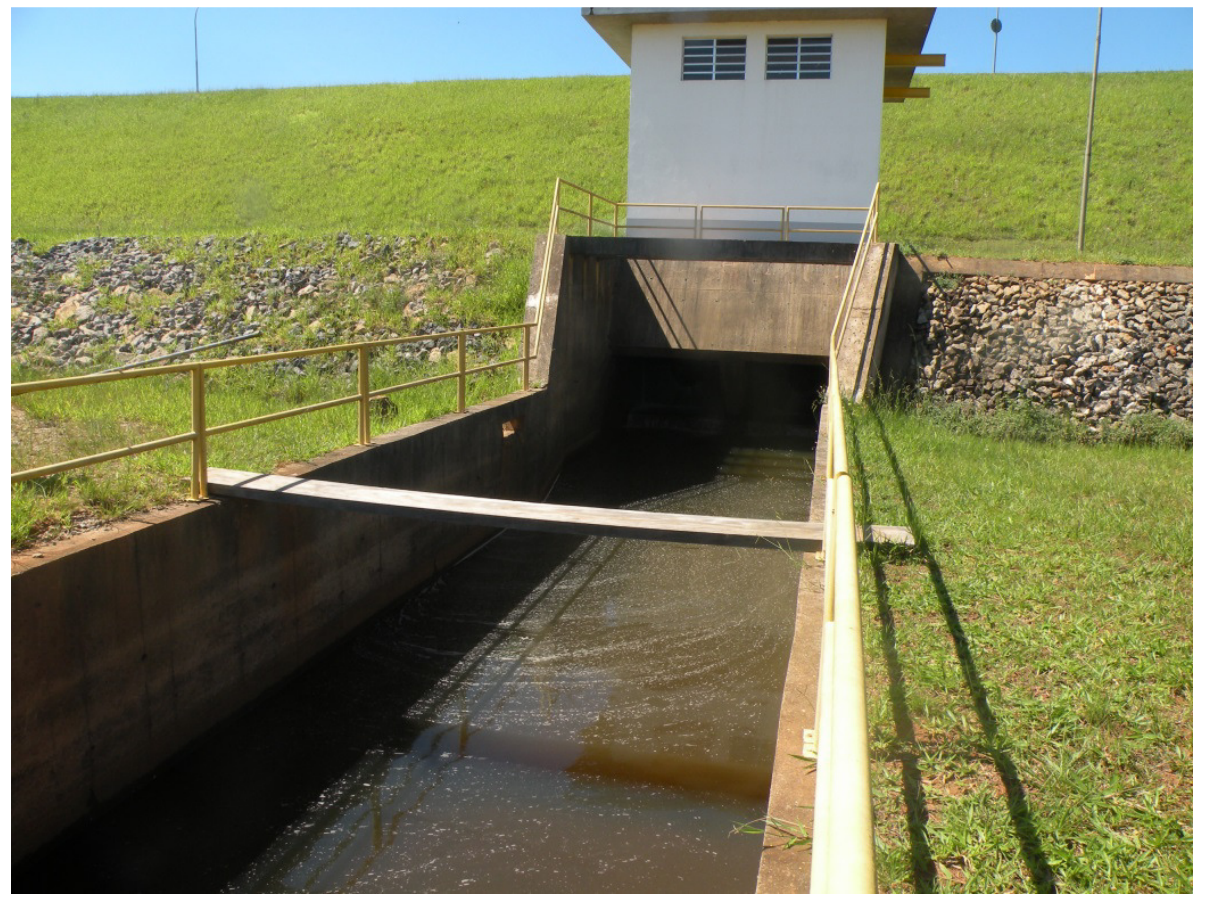

Figura 4-5 - Posto fluvissedimentométrico T5, no canal extravasor da tomada d'água TA-2. Ao fundo, vista do talude de jusante do maciço. 
Tabela 4-1 - Localização dos postos fluvissedimentométricos

\begin{tabular}{clcccl}
\hline Posto & Rio & UTM E $(\mathbf{m})$ & UTM N $(\mathbf{m})$ & Zona & Cidade \\
\hline T1 & Taiaçupeba Mirim & 365.191 & 7.385 .604 & $23 \mathrm{~S}$ & Suzano/SP \\
T2 & Balainho & 369.073 & 7.383 .358 & $23 \mathrm{~S}$ & Suzano/SP \\
T3 & Taiaçupeba Guaçu & 371.743 & 7.381 .821 & $23 \mathrm{~S}$ & Suzano/SP \\
T4 & Canal JU-TA & 373.791 & 7.384 .572 & $23 S$ & Mogi das Cruzes/SP \\
T5 & Canal extravasor & 368.440 & 7.392 .790 & $23 S$ & Suzano/SP \\
\hline
\end{tabular}

A vazão foi estimada com molinete fluviométrico, pelo método áreavelocidade, conforme proposto por Buchanan e Somers (1976). Cada seção transversal foi dividida em incrementos iguais de largura (mínimo 24 e máximo 48), de modo que cada incremento contivesse menos de $5 \%$ da vazão total (aceitável até $10 \%$ ), e a velocidade média de $90 \mathrm{~s}$ (a uma taxa de $1 \mathrm{~Hz}$ ) foi tomada no eixo vertical central de cada incremento. O molinete foi posicionado em um ponto, a $60 \%$ da profundidade ${ }^{5}$ para colunas d'água de até $0,75 \mathrm{~m}$, e em dois pontos, a $20 \%$ e $80 \%$, para colunas d'água maiores que $0,75 \mathrm{~m}$. A vazão média observada foi obtida pela Equação (25):

$$
Q=\left(V_{1} \times A I_{1}\right)+\left(V_{2} \times A I_{2}\right)+(\ldots)+\left(V_{N} \times A I_{N}\right)
$$

onde $V_{1,2, \ldots N}$ é velocidade média em cada incremento de largura e $A I_{1,2, \ldots N}$ é a área do incremento.

A amostragem de sedimentos em suspensão foi executada pelo método de igual incremento de largura, proposto por Edwards e Glysson (1999) e apresentado na Figura 4-6. Foi utilizado um amostrador isocinético US DH-48, com garrafa de 0,5 $L$ e bico de 1/4 pol, projetado para obtenção de amostras por integração na vertical, em canais de até $2,75 \mathrm{~m}$. A zona não amostrável, distância entre o bico e a base do amostrador, é de aproximadamente $9 \mathrm{~cm}$.

${ }^{5}$ Considera-se a origem na superfície e $100 \%$ no leito. 


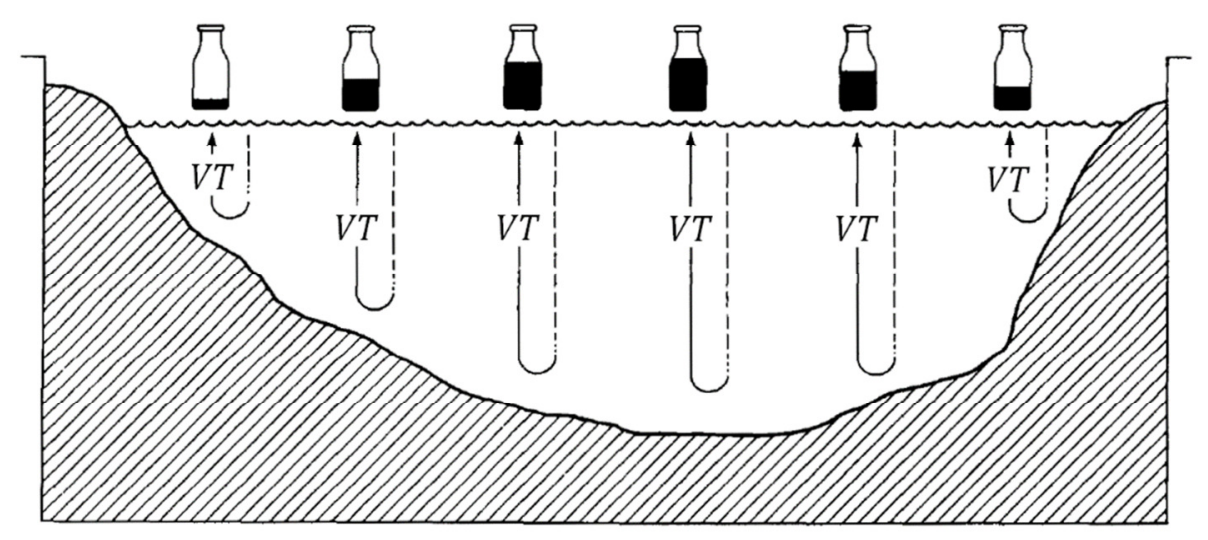

Figura 4-6 - Método de igual incremento de largura, onde a velocidade de transito $(V T)$ é constante. Fonte: adaptado de Edwards e Glysson (1999).

As seções transversais foram divididas em 10 verticais e a velocidade de trânsito do amostrador foi definida na vertical mais profunda, de modo a preencher no máximo $3 / 4$ de volume da garrafa. Essa regra prática garante que a taxa de redução do volume de ar dentro da garrafa seja menor que a taxa de aumento da pressão hidrostática, para uma amostragem isocinética. A velocidade de trânsito foi mantida constante em todas as verticais, conforme premissa do método.

As subamostras foram reunidas em uma única amostra e a concentração de sedimentos em suspensão ( $C S S$ ) foi obtida em laboratório pelo método da evaporação, conforme descrito em Carvalho (2008). A descarga sólida de suspensão $\left(Q_{s s}\right)$ foi estimada pela Equação (26):

$$
Q_{s S}=Q \times C S S \times 0,0864
$$

onde o coeficiente 0,0864 converte o resultado de $Q_{s s}$ para a unidade t/d.

As campanhas foram planejadas sob cronograma hidrológico, de acordo com o regime de chuvas, a fim de cobrir a maior amplitude possível das condições de escoamento. Durante o monitoramento, a previsão de chuva na área de estudo e as condições em tempo real dos radares meteorológicos ${ }^{6}$ foram rotineiramente observadas, uma vez que não havia posto telemétrico em operação para

${ }^{6}$ As informações dos radares meteorológicos do Brasil são disponibilizadas pelo Centro de Previsão de Tempo e Estudos Climáticos do Instituto Nacional de Pesquisas Espaciais, no endereço http://sigma.cptec.inpe.br/radar/\#, e pelo aplicativo móvel SOS Chuva, disponível em https://play.google.com/store/apps/details?id=br.inpe.cptec.soschuva.campinas\&hl=pt BR. 
acompanhamento do nível d'água dos canais, forma mais apropriada para planejamento de campanhas sob um cronograma hidrológico.

As medições e amostragens foram realizadas a vau ou sobre pontes, nos postos T2, T3 e T4, e sobre uma plataforma de madeira, no posto T5. Exclusivamente no posto $\mathrm{T} 1$, pela presença de galeria de passagem, formada por dois tubos metálicos circulares, de diâmetro $2 \mathrm{~m}$, o método foi adaptado para apenas uma vertical, no centro da seção de jusante de cada tubo. Nesse posto, foram realizadas medições de velocidade em um ponto a $60 \%$ da profundidade e amostragens de sedimentos em suspensão por integração em uma única vertical, com baixa velocidade de trânsito, ou pontual, preenchendo o volume máximo de 3/4 da garrafa.

A granulometria do sedimento em suspensão e do material do leito, dos postos T1 a T4, foi caracterizada em laboratório pelo método do peneiramento (nas frações areia e cascalho) e pelo método do densímetro (nas frações finas, silte e argila), segundo procedimentos recomendados por Carvalho (2008), e os dados obtidos foram convertidos para a classificação da American Geophysical Union. O material do leito foi coletado com um amostrador do tipo raspador, modelo Rock Island Simplificado (FEDERAL INTERAGENCY SEDIMENTATION PROJECT, 1940), ou do tipo draga, modelo Van Veen, composto por três subamostras, uma do centro da seção transversal do posto e outras duas próximas ao pé dos taludes marginais.

\subsubsection{Curvas de sedimento}

As curvas de sedimento foram desenvolvidas em linguagem de programação estatística $R$ (R DEVELOPMENT CORE TEAM, 2008) pelo método de regressão não linear de mínimos quadrados, na forma de funções do tipo potencial, representada na Equação (27), conforme proposto por Asselman (2000):

$$
C S S=a Q^{b}
$$

onde $a$ e $b$ são os coeficientes da regressão, CSS a variável dependente e $Q$ a variável explicativa. A aleatoriedade e a normalidade dos resíduos foram avaliadas 
graficamente e pelo teste de aderência não paramétrico de Anderson Darling, conforme proposto por Naghettini e Pinto (2007). Segundo esses autores(NAGHETTINI; PINTO, 2007), estatísticas não-paramétricas são aquelas que se baseiam em características que podem ser deduzidas dos dados amostrais, mas que não os incluem diretamente em seu cálculo. Uma vez que as premissas de aleatoriedade, independência, homogeneidade e estacionariedade frequentemente não são atendidas pelas variáveis hidrológicas, estas devem ser testadas apenas com o emprego dos testes não paramétricos.

O grau de correlação do modelo de regressão foi testado pelo coeficiente não paramétrico Tau de Kendall (KENDALL, 1975), cuja interpretação é semelhante à do coeficiente de correlação de Pearson, indicando alta correlação positiva entre dados observados e estimados para valores próximos da unidade e alta correlação negativa para valores próximos de -1. A eficiência do modelo de regressão foi avaliada pelo índice $R^{2}$ de Nash-Sutcliffe (NASH; SUTCLIFFE, 1970), descrito pela Equação (28):

$$
R^{2}=\frac{F_{0}^{2}-F^{2}}{F_{0}^{2}}
$$

onde $F_{0}^{2}$ é a variância inicial, Equação (29), e $F^{2}$ é a variância residual, Equação (30):

$$
\begin{aligned}
& F_{0}^{2}=\sum(C S S-\overline{C S S})^{2} \\
& F^{2}=\sum\left(C S S^{\prime}-C S S\right)^{2}
\end{aligned}
$$

onde $C S S^{\prime}$ é a concentração de sedimentos em suspensão estimada pelo modelo de regressão e $\overline{C S S}$ é a média das observações. O método de regressão foi desenvolvido apenas para os afluentes naturais do reservatório. 


\subsection{LEVANTAMENTO DAS SEÇÕES TRANSVERSAIS}

O levantamento topográfico consistiu na obtenção do comprimento do trecho de cada canal e na planialtimetria de seções transversais representativas, ao longo dos segmentos fluviais. Em todos os casos, os postos fluvissedimentométricos representaram o limite de montante do trecho de interesse da modelagem, enquanto a zona de remanso representou o limite de jusante, compreendendo o baixo curso da bacia.

O comprimento dos segmentos fluviais $(L)$ foi obtido pela vetorização do eixo central dos canais, sobre as ortofotocartas do Projeto de Atualização Cartográfica do Estado de São Paulo, executado pela Empresa Paulista de Planejamento Metropolitano (2012), com resolução espacial aproximada de $1 \mathrm{~m}$ e compatível com a escala 1:10.000. O Padrão de Exatidão Cartográfico desse produto é Classe A, com erro máximo esperado de $0,5 \mathrm{~mm}$ na escala da carta, ou, $5 \mathrm{~m}$ no terreno.

Para a execução do perfil planialtimétrico das seções transversais, foi utilizada uma solução de mapeamento, proposta por Costa e Araujo (2013), composta por um hipsômetro-telêmetro laser e um receptor Differential Global Positioning System ${ }^{7}$ (DGPS) para aplicações de cadastramento em Sistema de Informações Geográficas. Segundo Castillo et al. (2012), comparada com equipamentos topográficos de referência, como estações totais, são esperados erros percentuais (em área) da ordem de $10 \%$, com tendência de subestimação das seções transversais.

As seções foram selecionadas pela facilidade de acesso, preferencialmente em locais com travessias, e foi instalada uma estaca temporária em uma das margens $^{8}$, onde foram rastreadas observações GPS para georreferenciamento da seção. A partir desse marco, foram tomadas visadas transversais de ré e vante nos pontos de inflexão do relevo, locados com apoio de baliza e placa refletiva, ao longo

\footnotetext{
${ }^{7}$ Tipo de receptor GPS que permite armazenar os dados brutos das observações do código C/A para processamento do rastreio, com correções estimadas por estações-base em terra, reduzindo os efeitos advindos da disponibilidade seletiva, implantada no sistema para degradação do sinal transmitido e desativada em 2000, de acordo com Monico (2008).

${ }^{8}$ Define-se a margem esquerda e direita de uma seção fluvial olhando-se no sentido de jusante do canal.
} 
da área molhada, taludes marginais e da planície fluvial. As medidas de distância horizontal $(D H)$ e desnível $(D V)$, entre cada ponto locado e o eixo do instrumento, foram transformadas em pares ordenados $(x, y)$, de acordo com as Equações (31) e (32):

$$
\begin{gathered}
x=D H \\
y=D V+(H I-H B)
\end{gathered}
$$

onde $H I$ é a altura do instrumento ao solo e $H B$ é a altura da baliza, medida do ponto visado na placa refletiva ao solo.

De acordo com o padrão do sistema HEC-RAS, as seções foram numeradas a partir da última seção de jusante, seguindo em ordem crescente para montante, de forma que o número da seção indica o comprimento do segmento fluvial até a seção "zero". A origem das abscissas foi adotada no extremo esquerdo da planície fluvial e a escala das ordenadas foi definida pelo nivelamento.

O nivelamento das seções foi executado pelo método de posicionamento relativo estático com receptor do Global Navigation Satellite System (GNSS), baseado na estimativa das altitudes ortométricas ${ }^{9}$ de montante $\left(\theta_{m}\right)$ e jusante dos canais $\left(\theta_{j}\right)$. Foi utilizado um receptor topográfico de simples frequência (portadora L1), com antena OmniSTAR integrada para correção instantânea das pseudodistâncias ${ }^{10}$ e obtenção de precisão submétrica, em seções de rastreio de $30 \mathrm{~min}$, com intervalo de coleta de $15 \mathrm{~s}$, filtragem de satélites com ângulo de elevação inferior a $10^{\circ}$ e processamento pela estação-base POLI da Rede Brasileira de Monitoramento Contínuo dos Sistemas GNSS ${ }^{11}$ (RBMC), conforme

9 Altitude referida ao geóide, superfície de referência altimétrica adotada no Brasil, correspondente à superfície equipotencial que coincide com o nível médio dos mares não perturbados, de acordo com Instituto Brasileiro de Geografia e Estatística (2008).

${ }^{10}$ Segundo Monico (2008), as distâncias medidas entre os satélites do GNSS e o receptor são denominadas pseudodistâncias, em razão do não sincronismo entre o relógio do receptor e o dos satélites.

${ }^{11}$ A RBMC é composta por um conjunto de estações de rastreio contínuo, com coordenadas conhecidas, mantida pelo Instituto Brasileiro de Geografia e Estatística, cujos dados são disponibilizados em http://www.ibge.gov.br/home/geociencias/geodesia/rbmc/rbmc.shtm para aplicações geodésicas e topográficas. 
recomendações de Santos e Sá (2006).

Entretanto, a altitude ortométrica não advém diretamente das observações GNSS. A altitude medida pelos receptores é referida à superfície do elipsoide de revolução, adotado como referência para representação da superfície terrestre, e não tem significado físico. Essa altitude, denominada elipsoidal ou geométrica $(\varepsilon)$, relaciona-se à altitude ortométrica $(\theta)$ por meio da altura geoidal $(\delta)$, obtida pelo modelo de ondulação geoidal para aplicações de engenharia MAPGEO2015, desenvolvido pelo Instituto Brasileiro de Geografia e Estatística (2015), conforme Equação (33):

$$
\theta=\varepsilon-\delta
$$

Em virtude da seleção de um método de nivelamento com margem de erro submétrica, apenas as seções de montante e jusante, de cada canal, foram levantadas, de modo a fornecer uma estimativa da declividade média $(\Delta \theta / L)$, utilizada para nivelamento das seções intermediárias (Figura 4-7). Além disso, a altitude ortométrica da superfície d'água do reservatório também foi levantada, e comparada com o nível de operação medido pela régua oficial, a fim de corrigir as observações para adotar o mesmo datum altimétrico do reservatório. As altitudes elipsoidais $(\varepsilon)$ foram obtidas sobre o elipsóide GRS80, figura geométrica da Terra de referência para o sistema SIRGAS2000.

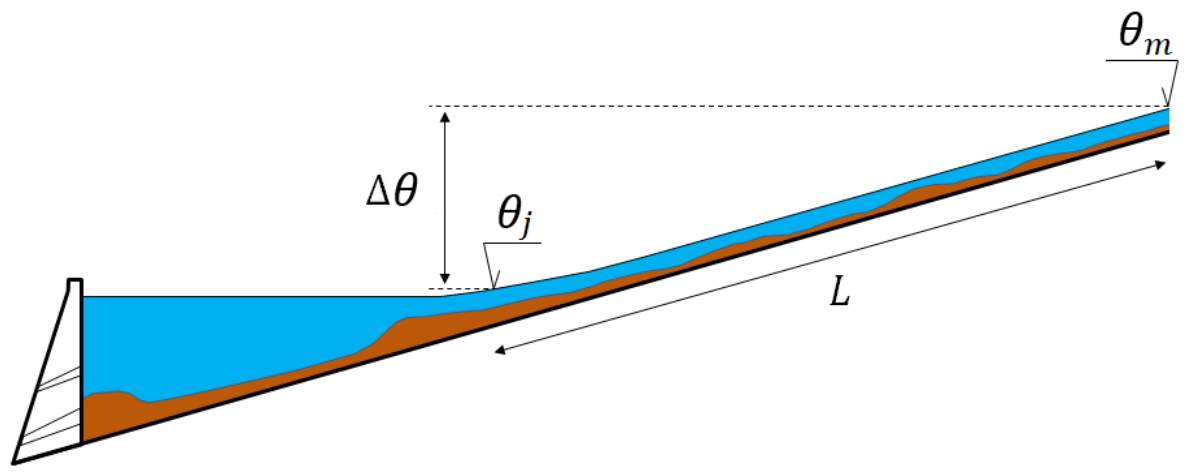

Figura 4-7 - Ilustração esquemática do método de nivelamento a partir do rastreio GNSS, para obtenção de altitudes ortométricas $(\theta)$ e da declividade média $(\Delta \theta / L)$ dos canais. 


\subsection{CALIBRAÇÃO, AJUSTE E VERIFICAÇÃO DO MODELO}

O desenvolvimento do modelo de transporte de sedimentos no HEC-RAS divide-se em duas etapas, a primeira na definição da geometria do sistema fluvial, para solução do perfil da linha d'água em regime permanente (modelo do escoamento), e a segunda com a introdução da rotina de cálculo do transporte de sedimentos, em regime quase permanente (modelo de fundo móvel).

Para definição da geometria do modelo foi necessário aplicar a interpolação linear entre seções levantadas, sendo necessário estabelecer uma distância máxima interpolada. Essa distância foi estabelecida pela análise qualitativa da solução da linha d'água ao longo dos canais modelados, de forma a obter a solução mais suavizada possível com o menor recurso computacional (quanto maior o número de seções, maior o consumo de tempo no processamento). Foram testadas geometrias com seções interpoladas a uma distância máxima de 10 m, 50 m, 100 m, 500 m e $1.000 \mathrm{~m}$. O coeficiente $n$ também foi interpolado nesse procedimento.

A calibração ${ }^{12}$ foi baseada na comparação das profundidades observadas e modeladas da coluna d'água, em cada seção transversal levantada, sendo conhecidas as condições de contorno de montante (vazão estimada no posto) e de jusante (nível do reservatório). Nessa etapa, o parâmetro de ajuste foi o coeficiente $n$, mandatório na solução do perfil da linha d'água.

Já para a verificação da geometria ajustada, foi realizada uma campanha independente de medição de vazão nos postos e de medição da profundidade da coluna d'água nas seções de levantamento topográfico. As vazões medidas foram utilizadas como condição de contorno de montante e as profundidades observadas foram comparadas às modeladas para aferir a acurácia do ajuste.

Para simular o escoamento no regime quase permanente, foram utilizados os registros de vazão diária dos postos fluviométricos do DAEE que, em conjunto com as curvas de sedimento, forneceram a descarga sólida de suspensão $\left(Q_{s s}\right)$, condição de contorno de montante. Para o canal JU-TA, foram utilizadas apenas a vazão e a

${ }^{12}$ Segundo INMETRO (2012), calibração é a comparação de um sistema de medição com padrões de referência, ajuste é o conjunto de operações realizadas no sistema de medição, de modo que ele forneça resultados correspondentes a determinados valores da grandeza a ser medida, e verificação é a evidência objetiva de que a grandeza medida satisfaz os requisitos especificados. 
descarga sólida médias observadas, em virtude do controle exercido pelo reservatório Jundiaí, a montante do posto $\mathrm{T} 4$. Em todos os casos, a descarga sólida foi subdividida por classe granulométrica, segundo os resultados da análise de granulometria do sedimento em suspensão. Foi adotada como condição de contorno de jusante a cota 743,50 m, cota operacional máxima até o ano de 2016, em virtude da licença ambiental da obra.

O período de simulação foi definido como igual ao tempo aproximado de operação do reservatório (41 anos, entre 1976 e 2017), tendo sido necessário estender a série de vazões diárias disponível, replicando-a de forma consecutiva. Para isso, o teste não paramétrico de Spearman, implementado em $\mathrm{R}$, conforme proposto por Naghettini e Pinto (2007), foi utilizado para verificar a existência de tendência temporal na série de dados.

Foi descartada a possibilidade de sintetizar séries de vazões diárias a partir de séries de precipitação, por modelos estocásticos, e calibrar um modelo determinístico de transformação chuva-vazão, conforme proposto por Nascimento e Kelman (1995). A modelagem estocástica demandaria aprofundados estudos hidrológicos e estatísticos em distribuição de probabilidades, para identificação e interpretação da aleatoriedade da precipitação na bacia, afastando-se dos objetivos desta pesquisa.

As funções de capacidade de transporte de sedimentos foram o principal parâmetro de ajuste do modelo de fundo móvel. Cada uma delas (Acker-White, Engelund-Hansen, Laursen-Copeland, Toffaleti e Yang) foi avaliada, combinando-se os métodos de encouraçamento de sedimentos no leito (Hirano e ThomasCopeland).

Uma vez que a rodada inicial do modelo apontou para um ajuste dos coeficientes $n$ muito superior às recomendações da literatura (BARNES JR, 1967; PORTO, 2006), foram aplicados fatores de 0,25, 0,5, 0,75 e 1,0 aos coeficientes $n$ preliminares, a fim de analisar a sensibilidade da resistência do escoamento frente à estabilidade morfológica do leito, ao longo da simulação. Essa análise de sensibilidade foi avaliada pelos resultados das variáveis de agradação $\left(\Delta Z_{a}\right)$ e degradação $\left(\Delta Z_{d}\right)$ máximas absolutas do leito e descarga sólida total $\left(Q_{s}\right)$ de cada canal. O somatório $Q_{s}$ de todo o sistema foi comparado à estimativa de assoreamento do reservatório para fins de verificação do modelo de fundo móvel.

Além das condições de contorno acima descritas, os seguintes parâmetros 
foram definidos no sistema HEC-RAS:

- temperatura média da água: $20{ }^{\circ} \mathrm{C}$;

- duração do escoamento: 24 h (frequência da série de vazões);

- incremento computacional: variável, entre $1 \mathrm{~h}$ e $24 \mathrm{~h}$, inversamente proporcional à vazão (quanto maior a vazão, maior a taxa de atualização da morfologia e menor o incremento, a fim de não induzir instabilidade no processamento);

- profundidade máxima de erosão: 0,25 m (considera-se, como premissa, que os canais do sistema Taiaçupeba encontram-se em condição de estabilidade morfológica, conforme observações de campo). 


\section{RESULTADOS}

São apresentados, a seguir, os principais resultados da pesquisa, com o apoio de gráficos, ilustrações esquemáticas e tabelas sumárias. O Apêndice A Plano de Gestão de Dados, apresenta a estrutura, organização e descrição dos dados brutos e derivados da pesquisa, bem como indica o Repositório de Dados designado para o seu armazenamento e disponibilização. A premissa desse plano é assegurar a integridade dos dados e registros desta pesquisa, aumentando seu potencial de replicação e permitindo que sejam compreensíveis e recuperáveis, no futuro, para permitir avanços no conhecimento científico e tecnológico.

\subsection{MONITORAMENTO FLUVISSEDIMENTOMÉTRICO}

O monitoramento fluvissedimentométrico foi executado entre 07 de outubro de 2013 e 24 de setembro de 2015 (dois anos hidrológicos). Em virtude do planejamento sob um cronograma hidrológico, a data e o número de campanhas em cada posto não são necessariamente coincidentes. No total, foram realizadas 102 campanhas, uma média de 20 por posto (Tabela 5-1 e Figura 5-1). As vazões observadas apontam que os afluentes naturais representaram, no período, aproximadamente $25 \%$ da vazão média afluente ao Taiaçupeba, sendo o restante garantido pela transposição das águas do reservatório Jundiaí. A descarga sólida afluente foi, predominantemente, proveniente da área natural de drenagem.

Comparando-se as vazões observadas às séries de vazões diárias dos postos fluviométricos do DAEE (Tabela 5-2), fica evidente a estiagem do período. Por esse motivo, os eventos amostrados não cobriram maior amplitude de condições de escoamento (Figura 5-2 a Figura 5-4). 
Tabela 5-1 - Estatística descritiva dos dados do monitoramento fluvissedimentométrico

\begin{tabular}{|c|c|c|c|c|c|c|}
\hline & & \multicolumn{5}{|c|}{ Posto fluvissedimentométrico } \\
\hline & & T1 & T2 & T3 & T4 & T5 \\
\hline \multicolumn{2}{|c|}{ Área de drenagem $\left(\mathrm{km}^{2}\right)$} & 68,3 & 35,7 & 97,8 & - & - \\
\hline \multicolumn{2}{|c|}{$N$} & 23 & 25 & 20 & 20 & 14 \\
\hline \multirow{4}{*}{$Q\left(\mathrm{~m}^{3} / \mathrm{s}\right)$} & Mínimo & 0,254 & 0,064 & 0,351 & 1,746 & 0,323 \\
\hline & Média & 0,763 & 0,295 & 0,932 & 8,452 & 1,128 \\
\hline & Máximo & 4,958 & 1,218 & 1,826 & 12,899 & 1,517 \\
\hline & Desvio padrão & 0,982 & 0,214 & 0,420 & 2,727 & 0,354 \\
\hline \multirow{4}{*}{$\operatorname{CSS}(\mathrm{mg} / \mathrm{L})$} & Mínimo & 4,0 & 0,4 & 0,3 & 1,2 & 0,8 \\
\hline & Média & 23,3 & 23,2 & 9,1 & 6,8 & 2,1 \\
\hline & Máximo & 227,2 & 333,3 & 43,3 & 30,6 & 3,1 \\
\hline & Desvio padrão & 45,9 & 65,1 & 10,0 & 7,0 & 0,6 \\
\hline \multirow[t]{4}{*}{$Q_{S S}(\mathrm{t} / \mathrm{d})$} & Mínimo & 0,1 & 0,002 & 0,009 & 1,1 & 0,1 \\
\hline & Média & 5,2 & 1,7 & 1,0 & 5,4 & 0,2 \\
\hline & Máximo & 97,3 & 35,1 & 6,8 & 28,0 & 0,3 \\
\hline & Desvio padrão & 20,2 & 7,0 & 1,6 & 7,0 & 0,1 \\
\hline
\end{tabular}

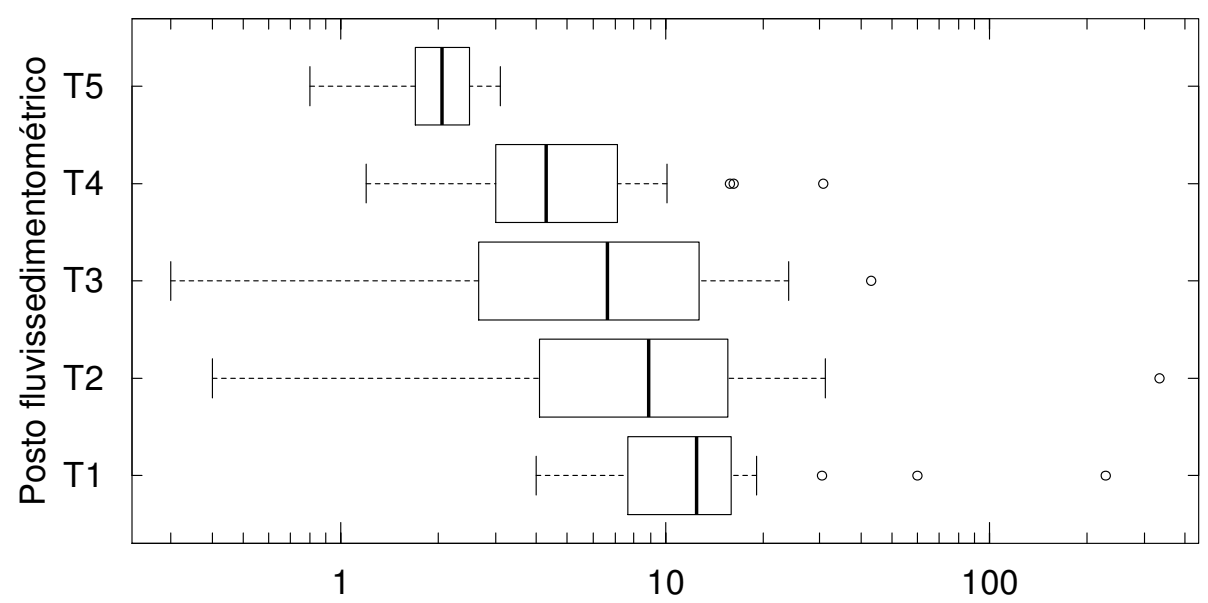

Concentração de sedimentos em suspensão, em miligramas por litro

Figura 5-1 - Box plot da concentração de sedimentos em suspensão. As linhas centrais das caixas indicam o segundo quartil (mediana) e seus limites indicam o primeiro quartil $(25 \%)$ e o terceiro quartil $(75 \%)$, respectivamente. As barras estendem-se desde o percentil 10 até 0 percentil 90 , e os dados amostrais fora dessa faixa são representados por círculos abertos. 
Tabela 5-2 - Estatística descritiva das vazões diárias dos postos fluviométricos do DAEE

\begin{tabular}{|c|c|c|c|c|}
\hline & & \multicolumn{3}{|c|}{ Posto fluviométrico } \\
\hline & & 3E-021 & 3E-015 & 3E-014 \\
\hline \multicolumn{2}{|l|}{ Rio } & Taiaçupeba Mirim & Balainho & Taiaçupeba Guaçú \\
\hline \multicolumn{2}{|c|}{ Área de drenagem $\left(\mathrm{km}^{2}\right)$} & 52 & 34 & 94,5 \\
\hline \multicolumn{2}{|l|}{ Período } & $\begin{array}{c}\text { 01/04/1962 - } \\
15 / 03 / 1976\end{array}$ & $\begin{array}{c}24 / 06 / 1960- \\
15 / 03 / 1976\end{array}$ & $\begin{array}{c}24 / 06 / 1960- \\
15 / 03 / 1976\end{array}$ \\
\hline \multicolumn{2}{|l|}{$N$} & 5.098 & 5.736 & 5.736 \\
\hline \multirow{4}{*}{$Q\left(\mathrm{~m}^{3} / \mathrm{s}\right)$} & Mínimo & 0,032 & 0,094 & 0,377 \\
\hline & Média & 0,677 & 0,477 & 1,701 \\
\hline & Máximo & 14,645 & 7,182 & 17,390 \\
\hline & Desvio padrão & 0,696 & 0,467 & 1,342 \\
\hline
\end{tabular}

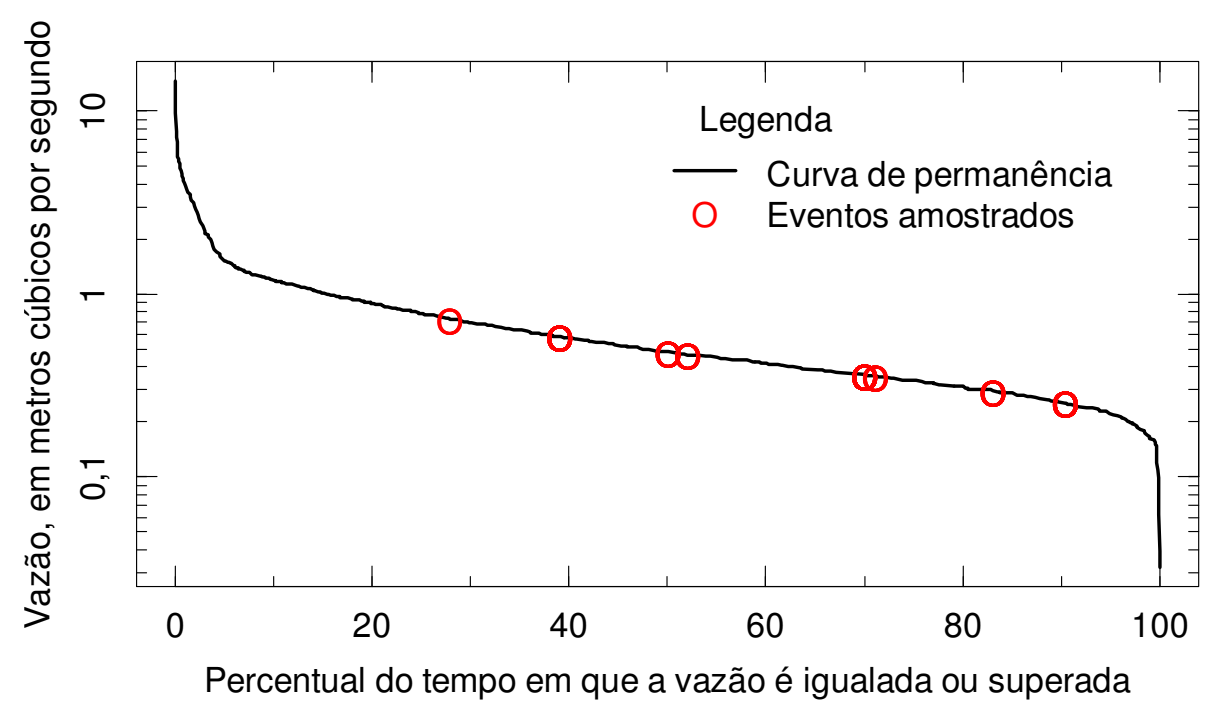

Figura 5-2 - Curva de permanência de vazões do posto 3E-021 (rio Taiaçupeba Mirim) e amostras de sedimento em suspensão, associadas às respectivas vazões medidas. 


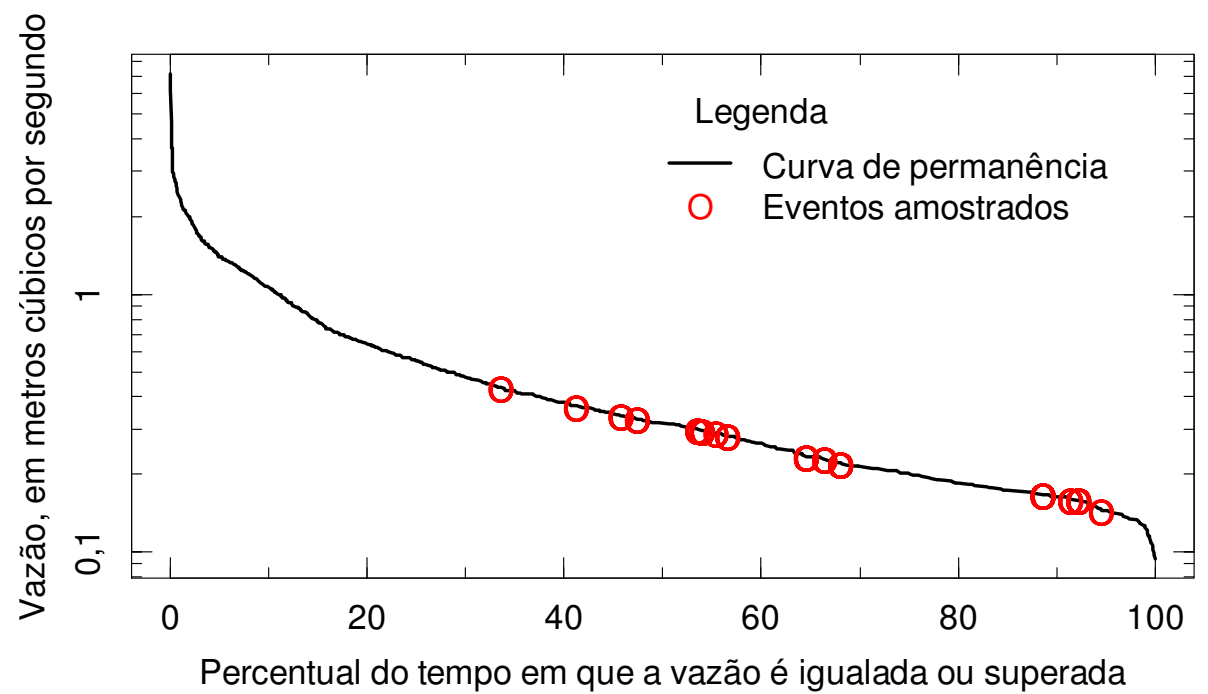

Figura 5-3 - Curva de permanência de vazões do posto 3E-015 (rio Balainho) e amostras de sedimento em suspensão, associadas às respectivas vazões medidas.

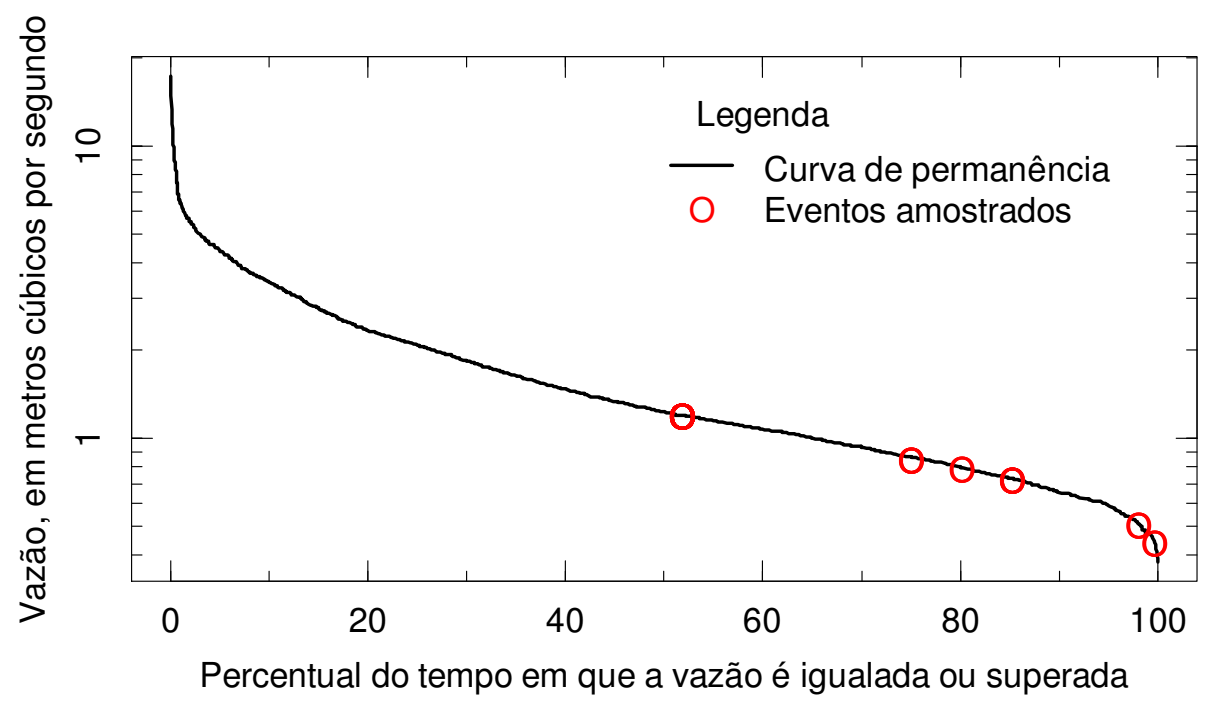

Figura 5-4 - Curva de permanência de vazões do posto 3E-014 (rio Taiaçupeba Guaçu) e amostras de sedimento em suspensão, associadas às respectivas vazões medidas.

As curvas de sedimento (Figura 5-5 a Figura 5-7) apresentaram bom ajuste dos coeficientes (Tabela 5-3), estatisticamente significativos a um nível de confiança de $95 \%$, com alta correlação positiva entre vazão e concentração de sedimentos em suspensão (coeficientes Tau de Kendall superiores a 0,65) e alta eficiência do modelo na previsão da variável dependente (índices $R^{2}$ superiores a 0,85 ). Os resíduos da regressão (Figura 5-8 a Figura 5-10) apresentaram-se aleatórios, centrados em zero, contudo não aderentes à distribuição normal, confirmando a necessidade do emprego de estatísticas não paramétricas na análise dos dados. 


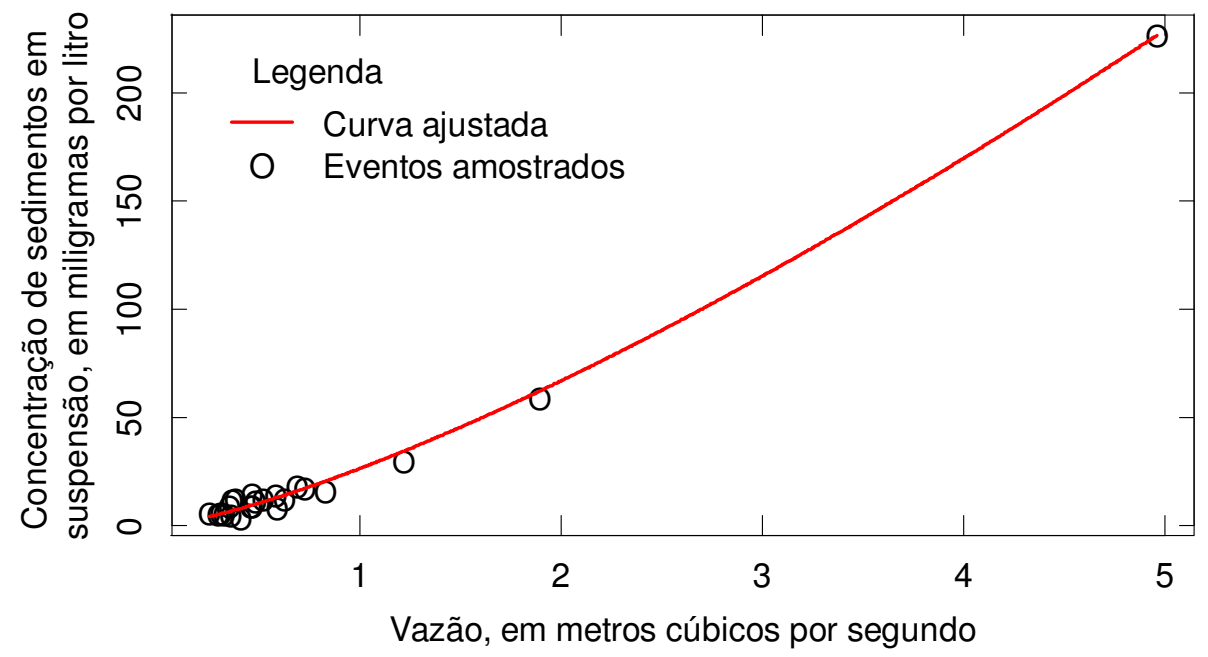

Figura 5-5 - Curva de sedimento ajustada para o posto T1.

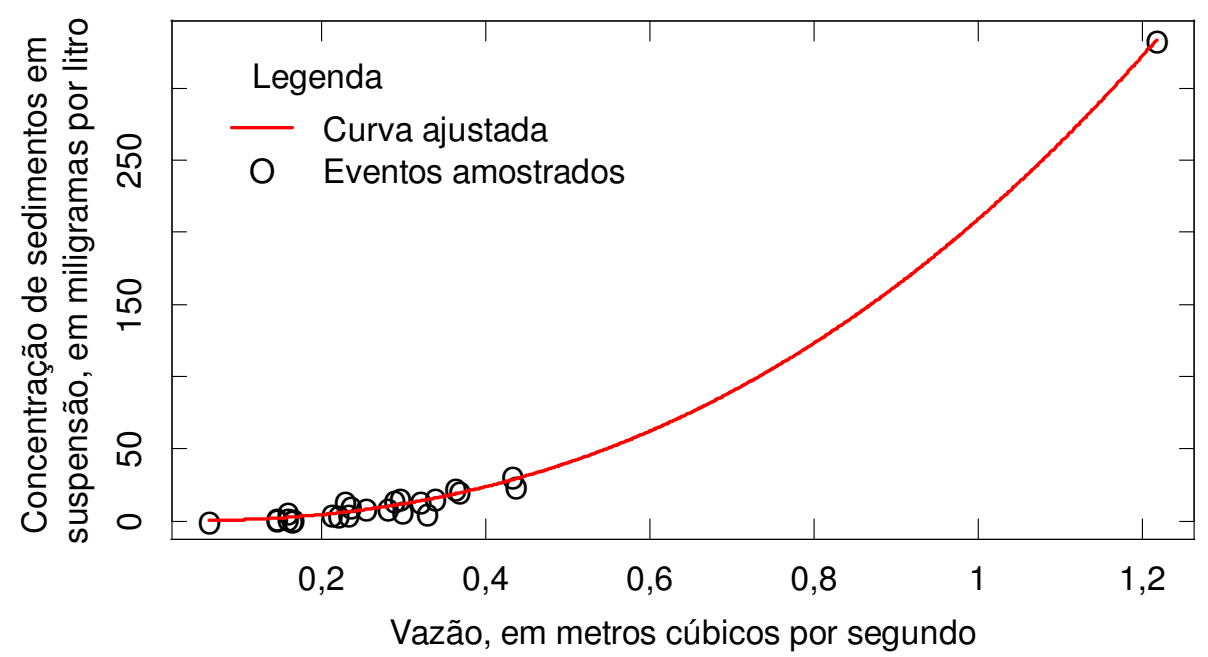

Figura 5-6 - Curva de sedimento ajustada para o posto T2.

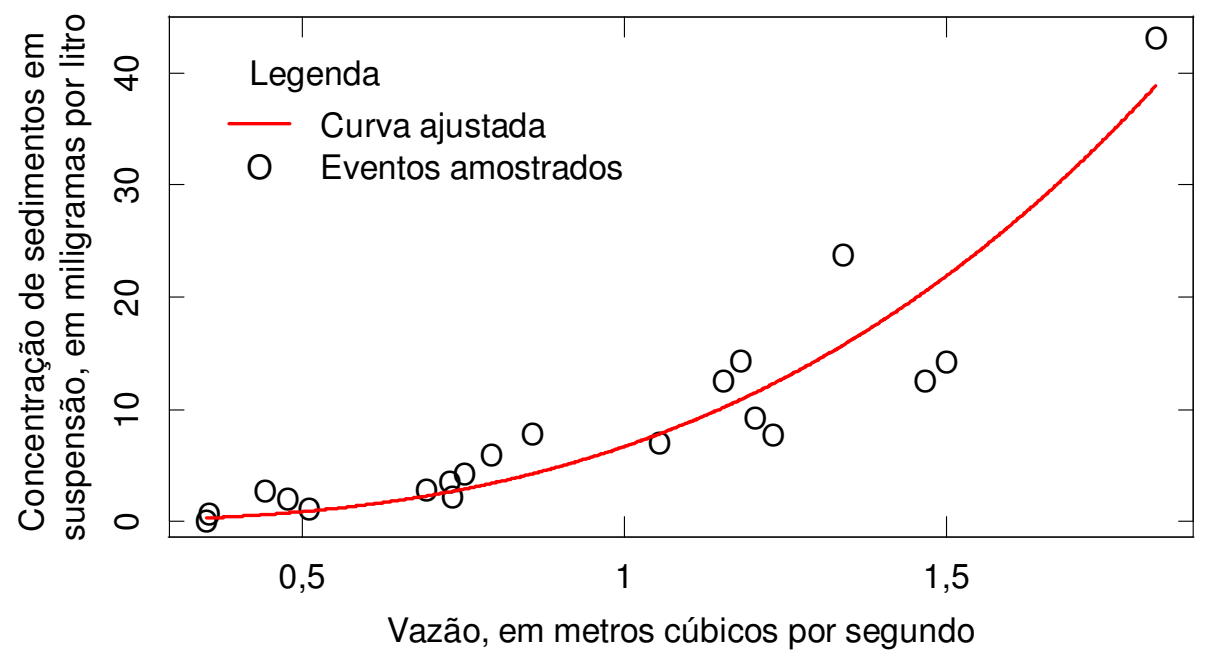

Figura 5-7 - Curva de sedimento ajustada para o posto T3. 
Tabela 5-3 - Sumário da análise de regressão não linear

\begin{tabular}{|c|c|c|c|c|c|c|}
\hline \multirow[b]{3}{*}{ Coeficiente } & \multicolumn{6}{|c|}{ Posto fluvissedimentométrico } \\
\hline & \multicolumn{2}{|c|}{ T1 } & \multicolumn{2}{|c|}{ T2 } & \multicolumn{2}{|c|}{ T3 } \\
\hline & $\mathrm{a}$ & $\mathrm{b}$ & $\mathrm{a}$ & $\mathrm{b}$ & $\mathrm{a}$ & $\mathrm{b}$ \\
\hline Estimativa & 26,350 & 1,344 & 208,783 & 2,371 & 6,687 & 2,921 \\
\hline Erro padrão & 1,038 & 0,026 & 2,701 & 0,047 & 1,137 & 0,360 \\
\hline Valor-p & $<2.10^{-16}$ & $<2.10^{-16}$ & $<2.10^{-16}$ & $<2.10^{-16}$ & $1,44.10^{-05}$ & $2,02.10^{-07}$ \\
\hline $\begin{array}{l}\text { Intervalo de } \\
\text { confiança 2,5\% }\end{array}$ & 24,191 & 1,289 & 203,195 & 2,272 & 4,298 & 2,164 \\
\hline $\begin{array}{l}\text { Intervalo de } \\
\text { confiança } 97,5 \%\end{array}$ & 28,508 & 1,398 & 214,371 & 2,469 & 9,075 & 3,678 \\
\hline Tau de Kendall & \multicolumn{2}{|c|}{0,655} & \multicolumn{2}{|c|}{0,731} & \multicolumn{2}{|c|}{0,818} \\
\hline $\begin{array}{l}R^{2} \text { de Nash- } \\
\text { Sutcliffe }\end{array}$ & \multicolumn{2}{|c|}{0,995} & \multicolumn{2}{|c|}{0,997} & \multicolumn{2}{|c|}{0,852} \\
\hline Anderson-Darling & \multicolumn{6}{|c|}{ Não aderente à distribuição normal ao nível de confiança de 95 \% } \\
\hline
\end{tabular}
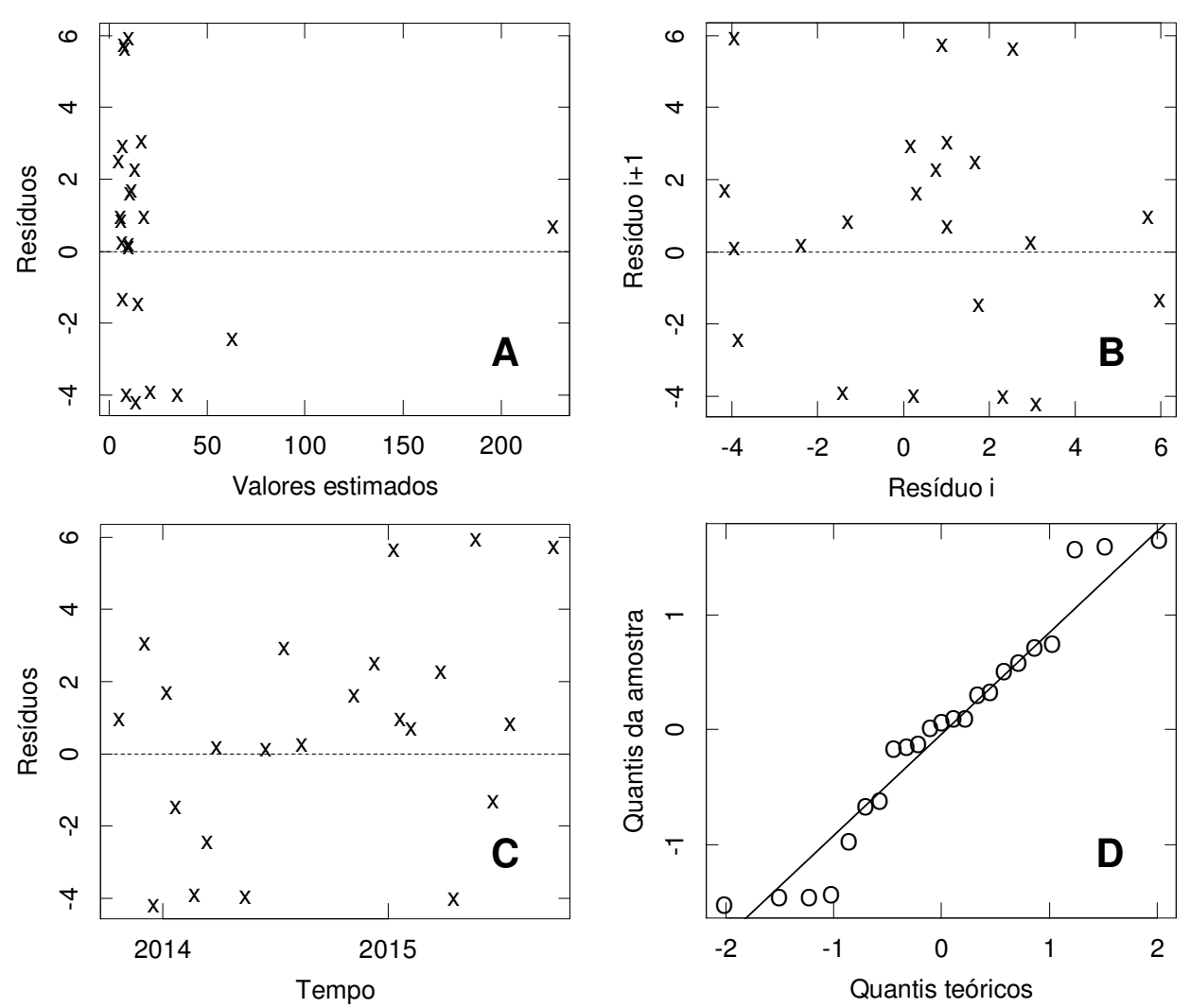

Figura 5-8 - Análise de aleatoriedade (A), auto correlação $(B)$, tendência temporal (C) e normalidade (D) dos resíduos da regressão do posto T1. 

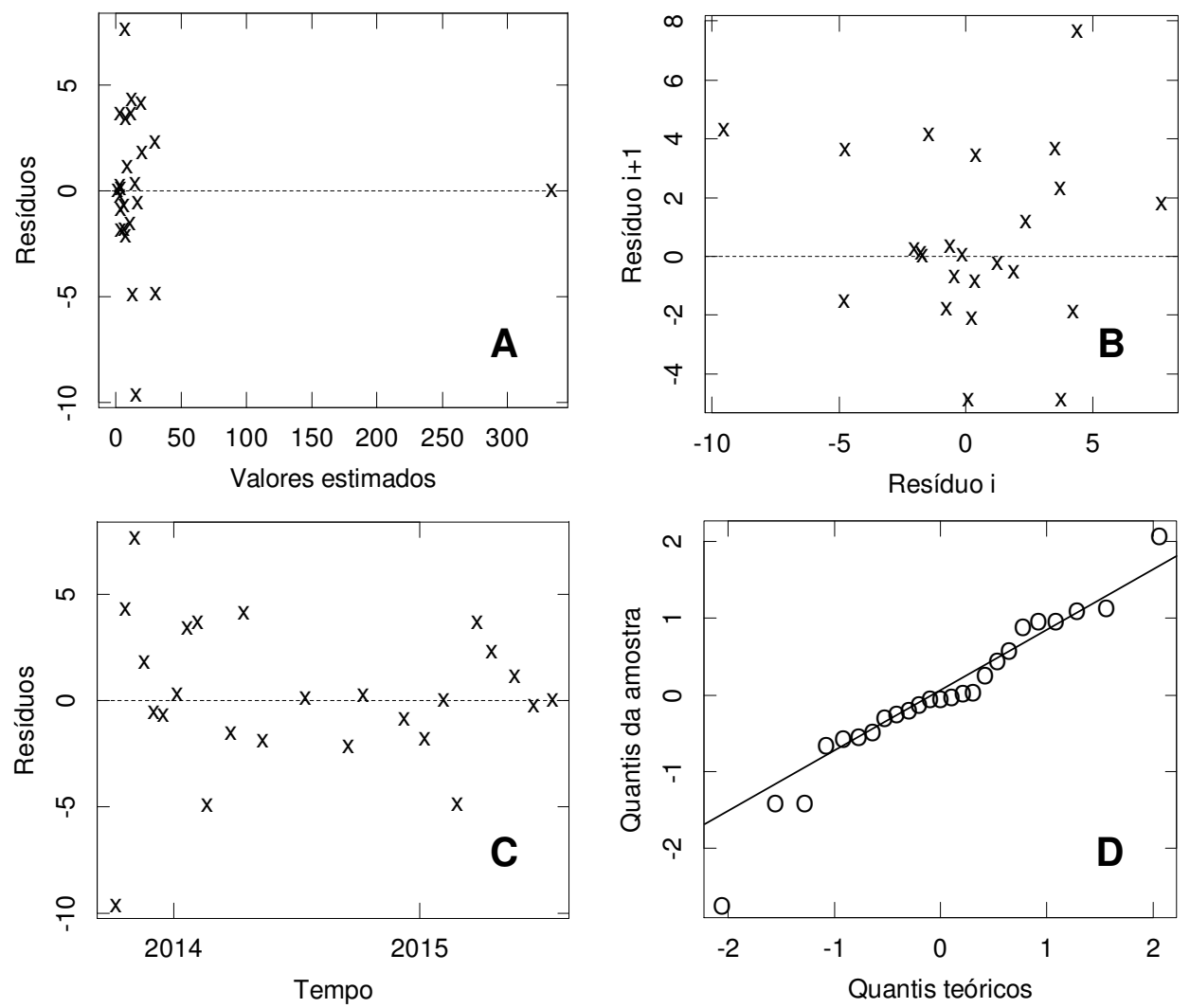

Figura 5-9 - Análise de aleatoriedade $(A)$, auto correlação $(B)$, tendência temporal (C) e normalidade (D) dos resíduos da regressão do posto T2.
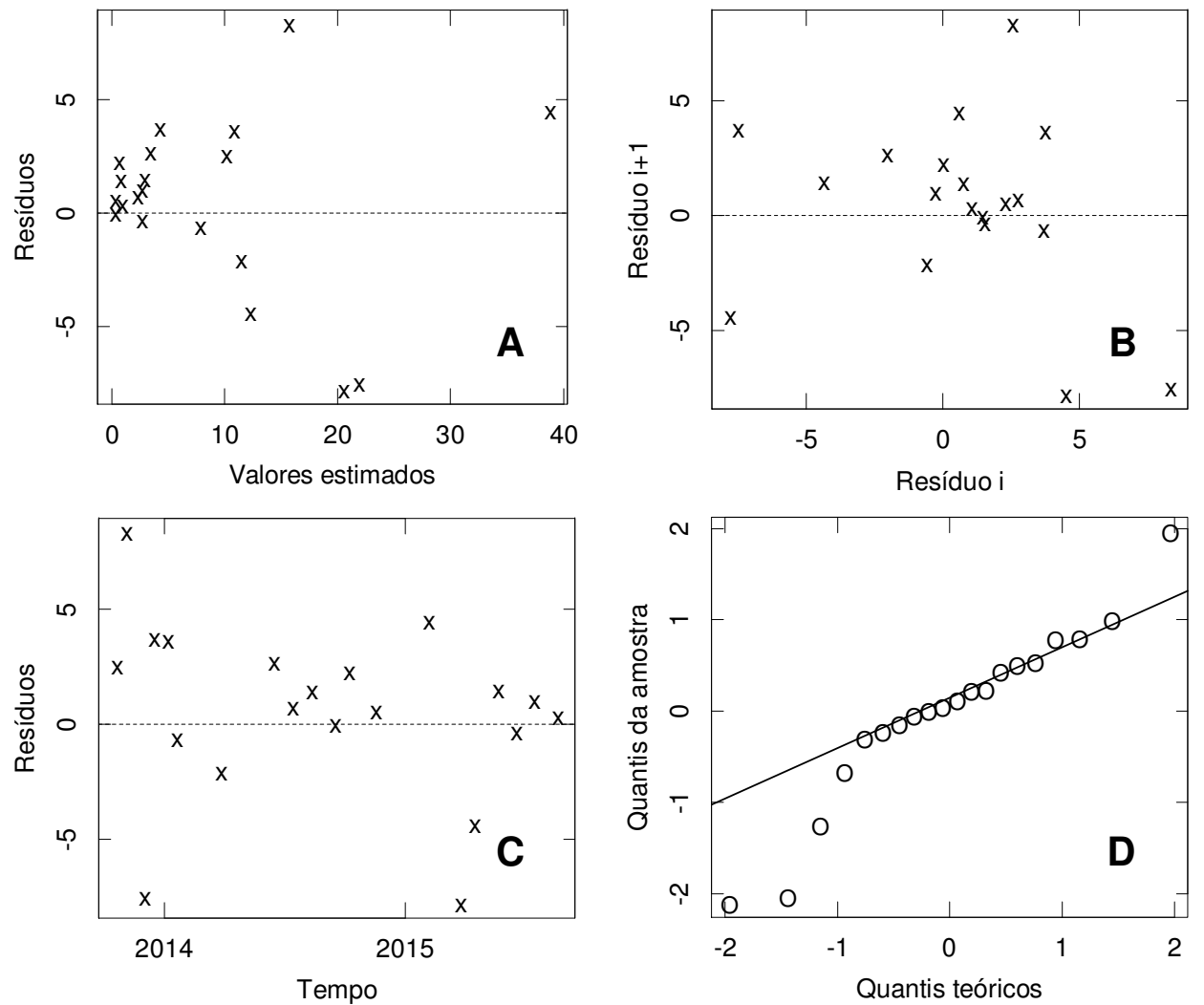

Figura 5-10 - Análise de aleatoriedade (A), auto correlação (B), tendência temporal (C) e normalidade (D) dos resíduos da regressão do posto T3. 
A amostragem de material de fundo para caracterização granulométrica (Figura 5-11) foi realizada na campanha de 18 de maio de 2015, resultando em um diâmetro $d_{50}$ de 0,564 $\mathrm{mm}$ para o rio Taiaçupeba Mirim (areia grossa), 0,181 mm para o rio Balainho (areia fina), 0,329 mm para o rio Taiaçupeba Guaçu (areia média) e 0,389 mm para o canal JU-TA (areia média).

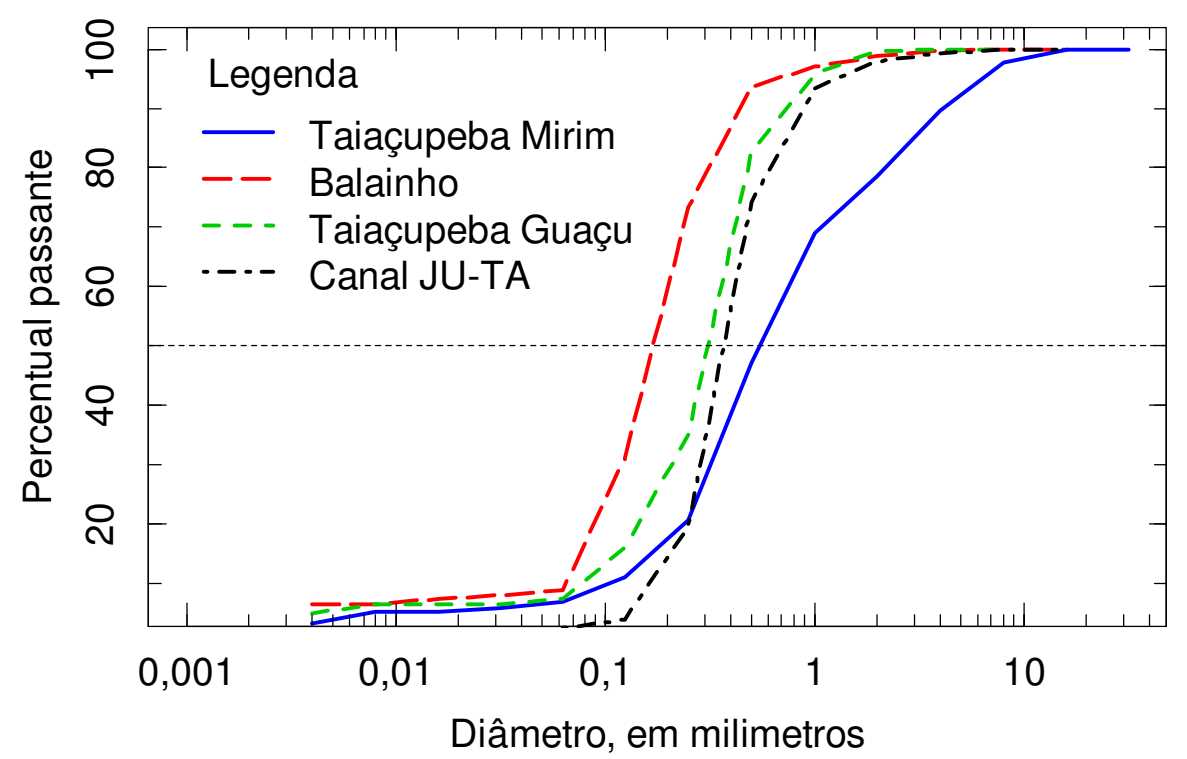

Figura 5-11 - Granulometria de fundo dos canais afluentes ao reservatório Taiaçupeba.

Já a granulometria do sedimento em suspensão foi caracterizada na campanha de 05 de fevereiro de 2015, cuja alta concentração de sedimentos permitiu a análise laboratorial pelos métodos propostos (Tabela 5-4). Observa-se a predominância de material fino (argila e silte, diâmetro inferior a 0,0625 mm), oriundo da carga de lavagem da bacia. 
Tabela 5-4 - Caracterização granulométrica das amostras de sedimentos em suspensão da campanha de 05 de fevereiro de 2015

\begin{tabular}{|c|c|c|c|c|c|}
\hline & & \multicolumn{4}{|c|}{ Posto fluvissedimentométrico } \\
\hline & & T1 & T2 & T3 & T4 \\
\hline \multicolumn{2}{|c|}{ Vazão medida (m³/s) } & 4,958 & 1,218 & 1,826 & 4,897 \\
\hline \multirow{6}{*}{$\begin{array}{l}\text { Percentual na } \\
\text { classe }\end{array}$} & $0,002 \mathrm{~mm}-0,004 \mathrm{~mm}$ & 8,7 & 10,3 & 10,4 & 13,3 \\
\hline & $0,004 \mathrm{~mm}-0,008 \mathrm{~mm}$ & 16,1 & 20,0 & 17,5 & 22,4 \\
\hline & $0,008 \mathrm{~mm}-0,016 \mathrm{~mm}$ & 32,2 & 34,7 & 35,9 & 27,1 \\
\hline & $0,016 \mathrm{~mm}-0,032 \mathrm{~mm}$ & 26,8 & 24,0 & 25,2 & 22,8 \\
\hline & $0,032 \mathrm{~mm}-0,0625 \mathrm{~mm}$ & 13,9 & 8,4 & 8,6 & 11,0 \\
\hline & $0,0625 \mathrm{~mm}-0,125 \mathrm{~mm}$ & 2,3 & 2,6 & 2,4 & 3,4 \\
\hline
\end{tabular}

\subsection{SEÇÕES TRANSVERSAIS}

Duas campanhas foram executadas para o levantamento planialtimétrico das seções transversais, em 18 de maio de 2015, ao longo do rio Balainho (Figura 5-12 e Figura 5-13), e em 05 de outubro de 2015, nos demais cursos d'água. No total, foram levantadas 17 seções transversais (Figura 5-14), o que corresponde, em média, a uma seção a cada $1,5 \mathrm{~km}$. Devido à presença de várzeas permanentemente encharcadas, com vegetação flutuante densa, as seções de número "zero" foram extrapoladas a partir dos dados das seções imediatamente a montante, e as seções 4295 e 4375, do rio Taiaçupeba Guaçu, nas imediações da confluência com o canal JU-TA, foram obtidas por interpolação.

O nivelamento foi executado em 03 de fevereiro de 2016. Ao longo das seções de rastreio, o Position Dilution of Precision ${ }^{13}$ (PDOP) máximo foi 2,8 e as precisões nominais variaram entre $0,1 \mathrm{~m}$ e 0,2 $\mathrm{m}$, após o processamento com dados da Estação POLI da RBMC. A altitude elipsoidal observada na superfície d'água do reservatório foi 740,676 m, rastreada próximo à régua oficial de nível (coordenadas UTM $368.363 \mathrm{~m}$ e $7.392 .099 \mathrm{~m}$ ), onde o valor da ondulação geoidal $(\delta)$ é igual a -

${ }^{13}$ Variável que representa a qualidade do posicionamento tridimensional, em função da geometria dos satélites. Segundo Instituto Brasileiro de Geografia e Estatística (2008), está relacionada ao inverso do volume do sólido formado pelas arestas que ligam o receptor aos satélites rastreados, e os satélites entre si, sendo que quanto menor o seu valor, maior o volume do sólido e melhor o resultado para o posicionamento. 
3,12 m. Aplicando-se a Equação (33), a altitude ortométrica resultou em 743,796 m, enquanto a régua registrava $743,43 \mathrm{~m}$. A diferença, equivalente a $-0,366 \mathrm{~m}$, foi aplicada às demais observações (Tabela 5-5), para padronização do datum altimétrico.

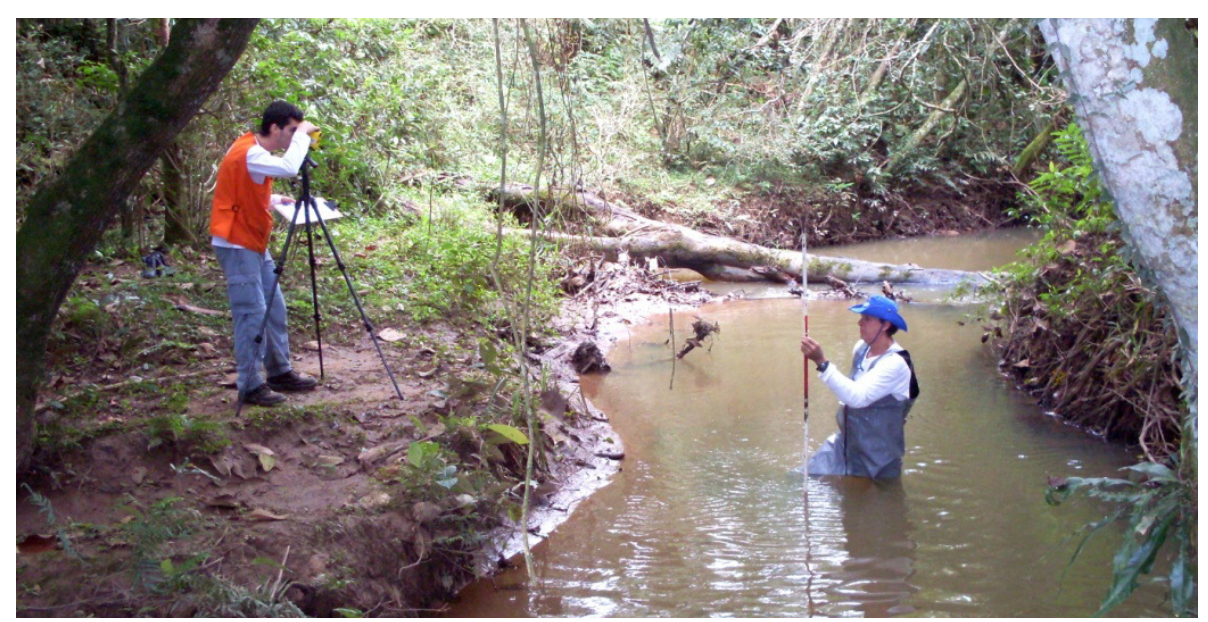

Figura 5-12 - Exemplificação do método de levantamento planialtimétrico, na seção transversal 6429 do rio Balainho.

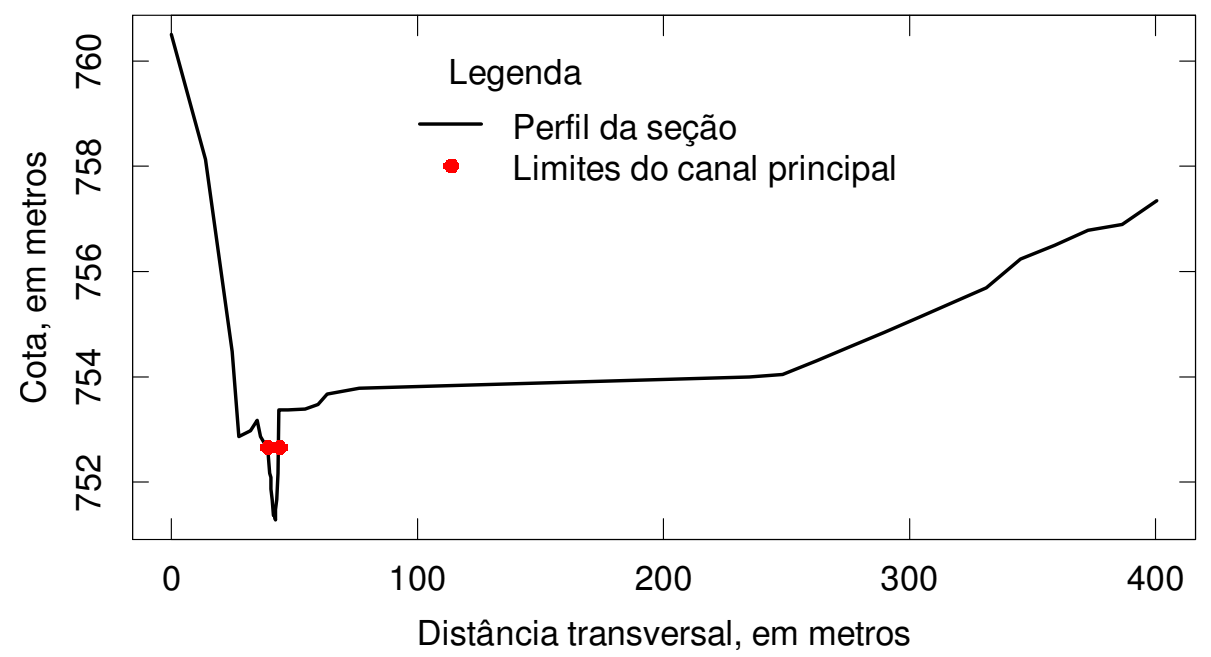

Figura 5-13 - Ilustração esquemática dos pares ordenados da seção transversal 6429 do rio Balainho. 


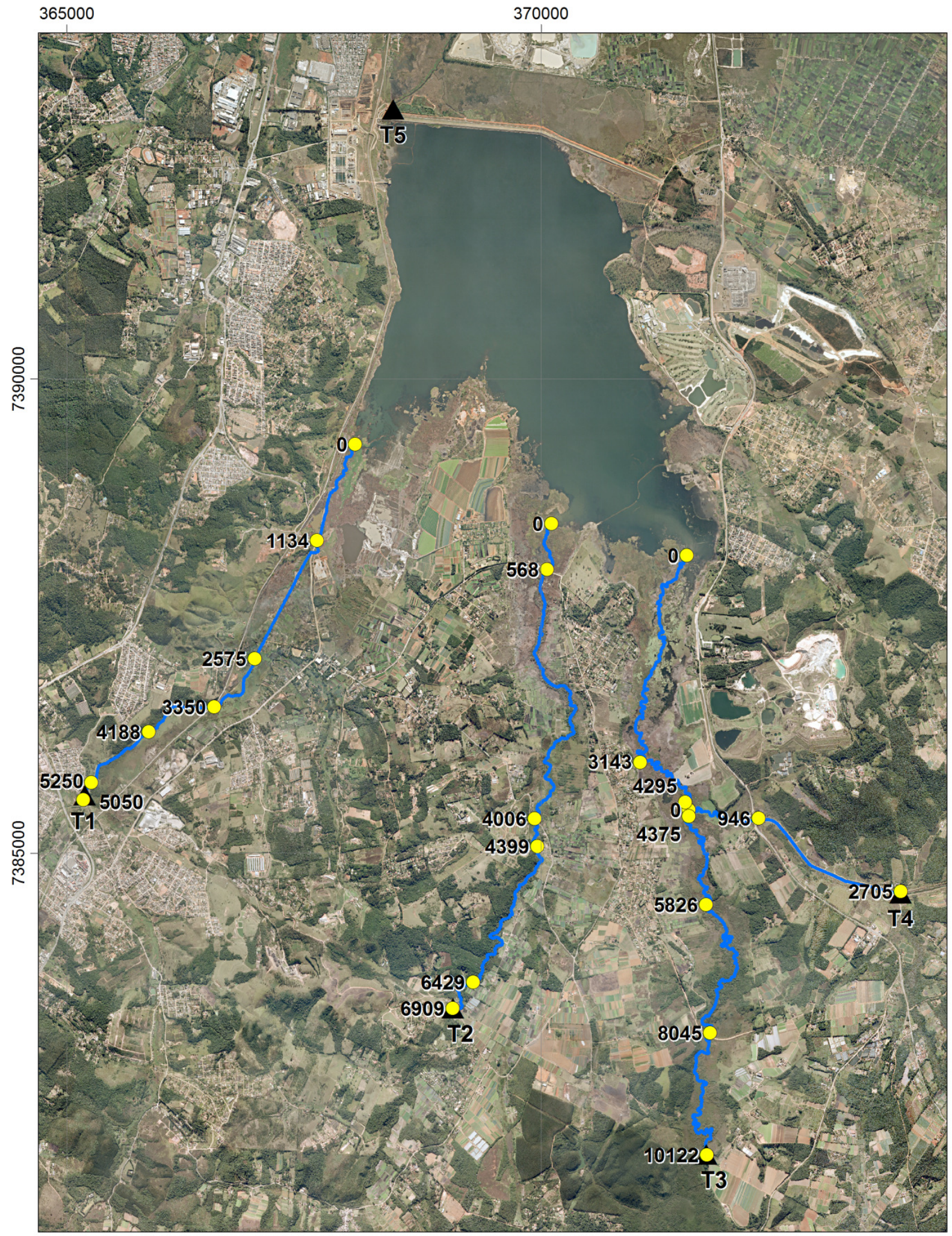

Legenda

Seções transversais

- Postos fluvissedimentométricos

Segmento fluvial vetorizado

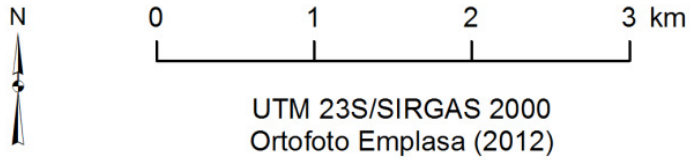

Figura 5-14 - Localização das seções transversais levantadas, onde o número da seção indica o comprimento do segmento fluvial até a seção "zero". 
Tabela 5-5 - Sumário dos resultados do nivelamento. As cotas corrigidas referem-se à altitude ortométrica corrigida para o datum altimétrico da régua do reservatório Taiaçupeba

\begin{tabular}{lcccccc}
\hline Rio & Seção & $\boldsymbol{\varepsilon}(\mathbf{m})$ & $\boldsymbol{\delta}(\mathbf{m})$ & $\boldsymbol{\theta}(\mathbf{m})$ & Cota corrigida $(\mathbf{m})$ & $\begin{array}{c}\text { Declividade } \\
\text { média }(\mathbf{m} / \mathbf{m})\end{array}$ \\
\hline Taiaçupeba & 5250 & 748.249 & -3.17 & 751.419 & 751.053 & 0,0013 \\
Mirim & 1134 & 743.030 & -3.14 & 746.170 & 745.804 & 0,0016 \\
\hline Balainho & 6909 & 751.218 & -3.23 & 754.448 & 754.082 & \\
& 568 & 740.897 & -3.17 & 744.067 & 743.701 & 0,0009 \\
\hline Taiaçupeba & 10122 & 747.883 & -3.31 & 751.193 & 750.827 & \\
Guaçu & 3143 & 741.600 & -3.22 & 744.820 & 744.454 & 0,0018 \\
\hline Canal JU- & 2705 & 748.892 & -3.31 & 752.202 & 751.836 & \\
TA & 946 & 745.856 & -3.26 & 749.116 & 748.750 & \\
\hline
\end{tabular}

\subsection{MODELO DO ESCOAMENTO}

A geometria do sistema fluvial foi representada à semelhança de um diagrama unifilar (Figura 5-15). Por tratar-se de um modelo unidimensional, apenas as dimensões (comprimento longitudinal, tomado ao centro dos canais, e largura transversal das seções) foram respeitadas, sem compromisso com a localização geográfica dessas feições. A interpolação das seções transversais com distância mínima de $100 \mathrm{~m}$ apresentou a melhor relação entre a solução da linha d'água (Figura 5-16).

Ressalta-se que o reservatório Taiaçupeba não foi representado geometricamente, mas seu nível operacional foi utilizado como condição de contorno de jusante no modelo, controlando a lâmina d'água e promovendo o efeito de remanso pela simulação das baixas velocidades de escoamento. 


\section{Legenda}

Curso d'água

Área inundada

Seção transversal levantada

Seção transversal interpolada

$\longrightarrow$ Sentido do escoamento

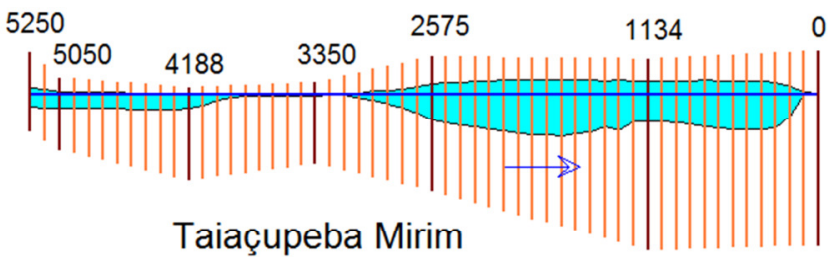

5680
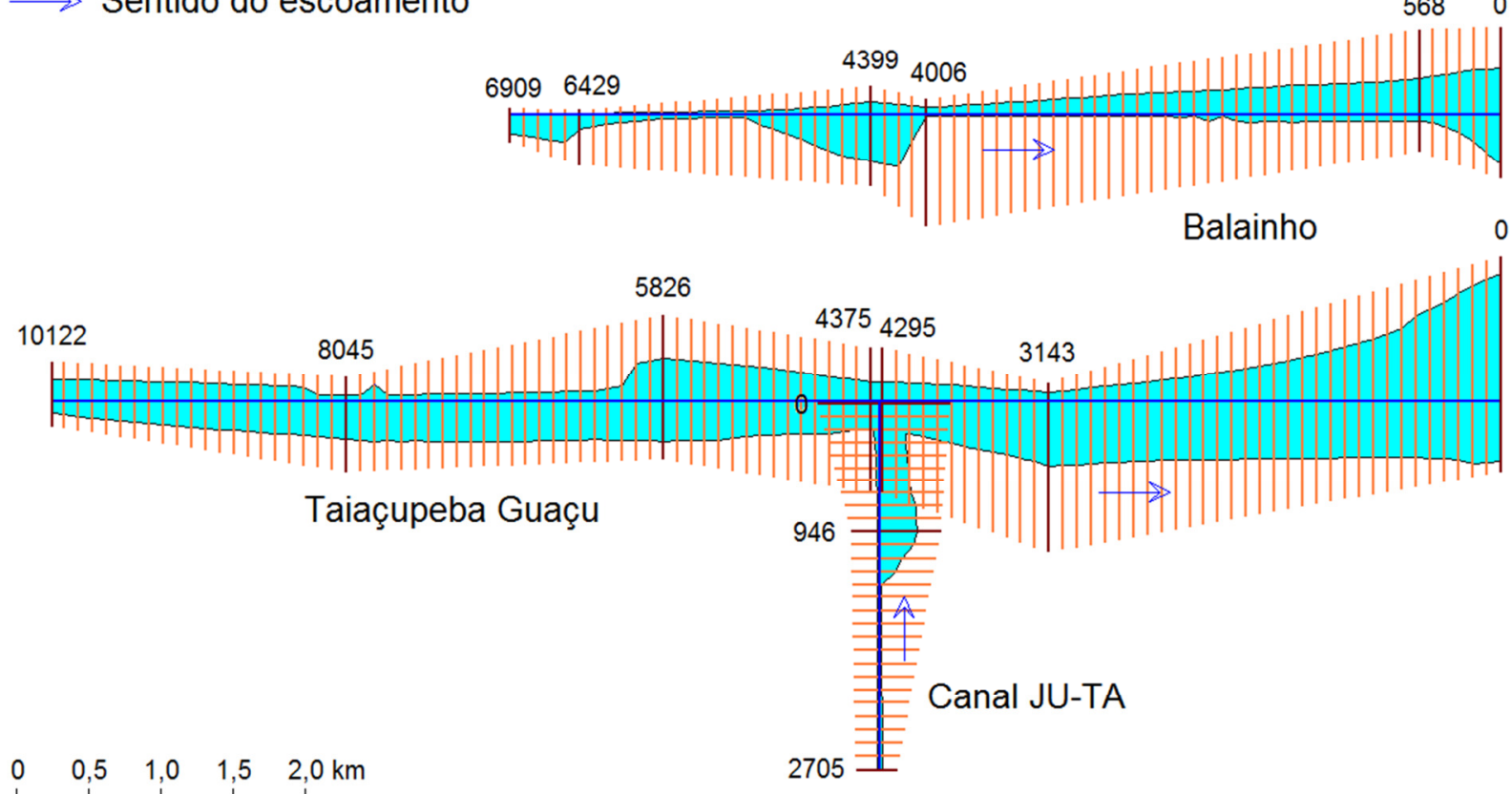

Figura 5-15 - Representação esquemática da geometria do sistema fluvial Taiaçupeba, apresentando o resultado da solução da linha d'água para vazões máximas de entrada no modelo $\left(14,645 \mathrm{~m}^{3} / \mathrm{s}\right.$ para o rio Taiaçupeba Mirim, 7,182 m³/s para o rio Balainho, $17,39 \mathrm{~m}^{3} / \mathrm{s}$ para o rio Taiaçupeba Guaçu e $8,452 \mathrm{~m}^{3} / \mathrm{s}$ para o canal JU-TA).

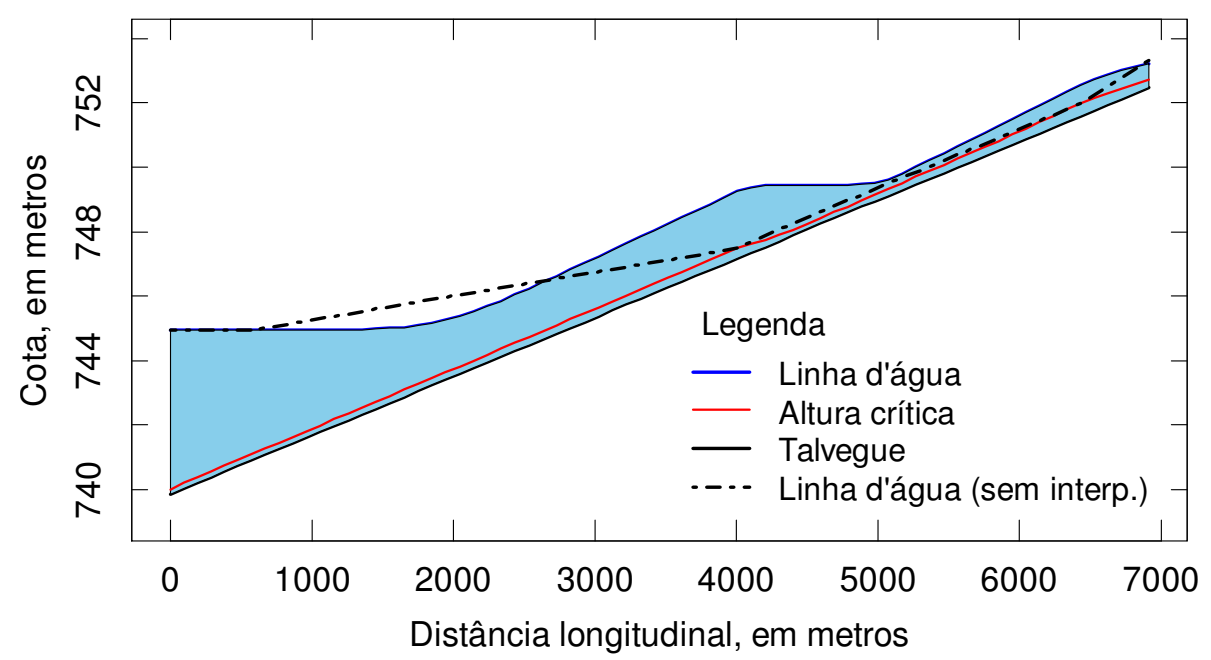

Figura 5-16 - Representação longitudinal do modelo de escoamento do rio Balainho, para $Q=0,476 \mathrm{~m}^{3} / \mathrm{s}$, cota do reservatório $744,93 \mathrm{~m}$ e seções interpoladas a cada $100 \mathrm{~m}$. A linha tracejada representa o resultado do cálculo do escoamento para uma geometria sem interpolação das seções. 
Para a calibração do sistema fluvial, foram utilizadas as profundidades máximas observadas nas campanhas de 18 de maio de 2015 e 05 de outubro de 2015, e as respectivas vazões medidas $\left(Q_{c}\right)$. Para a verificação, foram utilizados os dados oriundos da campanha independente de medição de vazões $\left(Q_{v}\right)$, conduzida em 07 de junho de 2017. Nessas três campanhas, o nível operacional do reservatório foi registrado em 742,60 m, 743,12 m e 744,93 m, respectivamente.

Os valores de $n$ preliminarmente ajustados (Tabela 5-6), conforme mencionado no item 4.3, foram superiores à ordem de grandeza esperada $\left(10^{-2}\right)$ para canais fluviais com as características da área de estudo. Sendo o coeficiente de Manning o único parâmetro de ajuste para solução da linha d'água, a solução matemática do modelo foi satisfeita com valores altos, incorporando tanto a representação física do fenômeno de resistência ao escoamento, quanto possíveis erros de medição do nível d’água e da geometria do sistema, conforme será discutido no item 6.2 .

Tabela 5-6 - Sumário da calibração e verificação do coeficiente $n$ para os canais principais

\begin{tabular}{|c|c|c|c|c|c|c|c|c|}
\hline \multirow{2}{*}{ Rio } & \multirow{2}{*}{ Seção } & \multirow{2}{*}{$\begin{array}{l}n \text { de Manning } \\
\text { ajustado }\end{array}$} & \multicolumn{3}{|c|}{ Calibração } & \multicolumn{3}{|c|}{ Verificação } \\
\hline & & & $Q_{c}\left(\mathrm{~m}^{3} / \mathrm{s}\right)$ & $Y(\mathrm{~m})$ & $Y^{\prime}(\mathrm{m})$ & $Q_{v}\left(\mathbf{m}^{3} / \mathbf{s}\right)$ & $Y(\mathrm{~m})$ & $Y^{\prime}(\mathrm{m})$ \\
\hline \multirow{6}{*}{ Taiaçupeba } & 5250 & 0,06 & \multirow{6}{*}{2,895} & 1,3 & 1,32 & \multirow{6}{*}{3,110} & 1,3 & 1,36 \\
\hline & 5050 & 0,07 & & 1,3 & 1,31 & & 1,4 & 1,36 \\
\hline & 4188 & 0,07 & & 1,5 & 1,44 & & 1,5 & 1,49 \\
\hline & 3350 & 0,05 & & 1,2 & 1,16 & & - & 1,21 \\
\hline & 2575 & 0,04 & & 1,7 & 1,65 & & 1,6 & 1,72 \\
\hline & 1134 & 0,25 & & 2,0 & 1,88 & & 2,3 & 2,26 \\
\hline \multirow{5}{*}{ Balainho } & 6909 & 0,09 & \multirow{5}{*}{0,450} & 0,7 & 0,71 & \multirow{5}{*}{0,476} & 0,7 & 0,73 \\
\hline & 6429 & 0,10 & & 0,9 & 0,93 & & 1,0 & 0,95 \\
\hline & 4399 & 0,20 & & 1,4 & 1,50 & & 1,5 & 1,55 \\
\hline & 4006 & 0,55 & & 2,1 & 2,02 & & 2,2 & 2,07 \\
\hline & 568 & 0,55 & & 2,0 & 1,81 & & 4,2 & 4,03 \\
\hline \multirow{4}{*}{$\begin{array}{l}\text { Taiaçupeba } \\
\text { Guaçu }\end{array}$} & 10122 & 0,14 & \multirow{4}{*}{1,587} & 1,6 & 1,54 & \multirow{4}{*}{3,153} & 2,1 & 2,11 \\
\hline & 8045 & 0,15 & & 1,2 & 1,26 & & 1,9 & 1,77 \\
\hline & 5826 & 0,02 & & 1,4 & 1,53 & & - & 1,89 \\
\hline & 3143 & 0,07 & & 3,1 & 2,96 & & 3,8 & 3,88 \\
\hline \multirow{2}{*}{ Canal JU-TA } & 2705 & 0,17 & \multirow{2}{*}{3,365} & 1,8 & 1,87 & \multirow{2}{*}{3,290} & 1,8 & 1,87 \\
\hline & 946 & 0,29 & & 2,8 & 2,65 & & 2,8 & 2,71 \\
\hline
\end{tabular}


Como não houveram campanhas durante eventos de cheia, adotou-se o coeficiente $n$ nas planícies fluviais como iguais ao valor máximo atribuído à cada canal principal. Em uma análise qualitativa (Figura 5-15), mediante a utilização das vazões máximas observadas nas séries históricas como condição de contorno de montante, as planícies de inundação resultaram coerentes com a topografia, sem erros de processamento ou formação de perfis de linha d'água descontínuos.

De forma geral, o regime de escoamento apresentou-se como subcrítico em todos os canais, com número de Froude máximo igual a 0,42 e termo de energia cinética máximo de 0,06 m (Tabela 5-7). Velocidades nulas foram observadas nas seções que representam a zona de remanso do reservatório, próximo às seções "zero".

Tabela 5-7 - Amplitude de variação dos principais parâmetros hidráulicos modelados, para todas as condições de escoamento simuladas

\begin{tabular}{lcccc}
\hline & \multicolumn{4}{c}{ Sistema fluvial } \\
\cline { 2 - 5 } & Taiaçupeba Mirim & Balainho & Taiaçupeba Guaçu & Canal JU-TA \\
\hline$V(\mathrm{~m} / \mathrm{s})$ & $0-0,84$ & $0-0,86$ & $0,01-1,05$ & $0,09-0,3$ \\
$Y(\mathrm{~m})$ & $0,12-3,63$ & $0,11-3,8$ & $0,31-5,54$ & $1,25-4,22$ \\
$B(\mathrm{~m})$ & $1,94-388,2$ & $1,94-710,76$ & $4,26-1.363,10$ & $8,19-472,85$ \\
$R(\mathrm{~m})$ & $0,07-1,9$ & $0,1-1,38$ & $0,15-1,57$ & $0,34-2,18$ \\
Froude & $0-0,21$ & $0-0,42$ & $0-0,26$ & $0,02-0,05$ \\
$\alpha V^{2} / 2 g(\mathrm{~m})$ & $0-0,04$ & $0-0,04$ & $0-0,06$ & $0-0,01$ \\
\hline
\end{tabular}

\subsection{MODELO DE FUNDO MÓVEL}

As séries de vazões diárias, replicadas de forma consecutiva para servir de dado de entrada do módulo de fundo móvel, apresentaram tendência temporal, demonstrada pelo teste não paramétrico de Spearman (Tabela 5-8). Não foi escopo desta pesquisa o estudo de modelos estocásticos para geração de séries sintéticas de vazão, conforme mencionado no item 4.3. Contudo, essa observação serve como alerta a estudos futuros que venham a utilizar essas séries de dados para fins preditivos, uma vez que, segundo Yue et al. (2002), no caso de existir uma componente determinística na série temporal, essa componente deve ser removida antes de se produzir o modelo estocástico. 
Tabela 5-8 - Resultados do teste não paramétrico de Spearman para as séries diárias de vazão dos postos fluviométricos do DAEE

\begin{tabular}{lccc}
\hline & \multicolumn{3}{c}{ Posto fluviométrico } \\
\cline { 2 - 4 } & 3E-021 & 3E-015 & 3E-014 \\
\hline Rio & Taiaçupeba Mirim & Balainho & Taiaçupeba Guaçú \\
Estatística do teste $(T)$ & 19,00 & 15,96 & 14,20 \\
Nível de confiança & $95 \%$ & $95 \%$ & $95 \%$ \\
Normal padrão $\left(z_{0.975}\right)$ & 1,96 & 1,96 & 1,96 \\
Hipótese nula $\left(H_{0}\right)$ & Como $|T|>z_{0,975}$, a decisão é de rejeitar a hipótese $H_{0}$ \\
& \multicolumn{2}{c}{ de que as observações não apresentam tendência } \\
\hline
\end{tabular}

Os sedimentogramas produzidos não apresentaram atrasos em sua evolução dinâmica, com relação ao hidrograma, durante a passagem de uma onda de cheia (Figura 5-17). Trata-se, contudo, de uma consequência da utilização da vazão como variável explicativa na curva de sedimentos, não sendo possível evidenciar a existência de histerese ${ }^{14}$ no regime de transporte de sedimentos para o sistema fluvial Taiaçupeba.

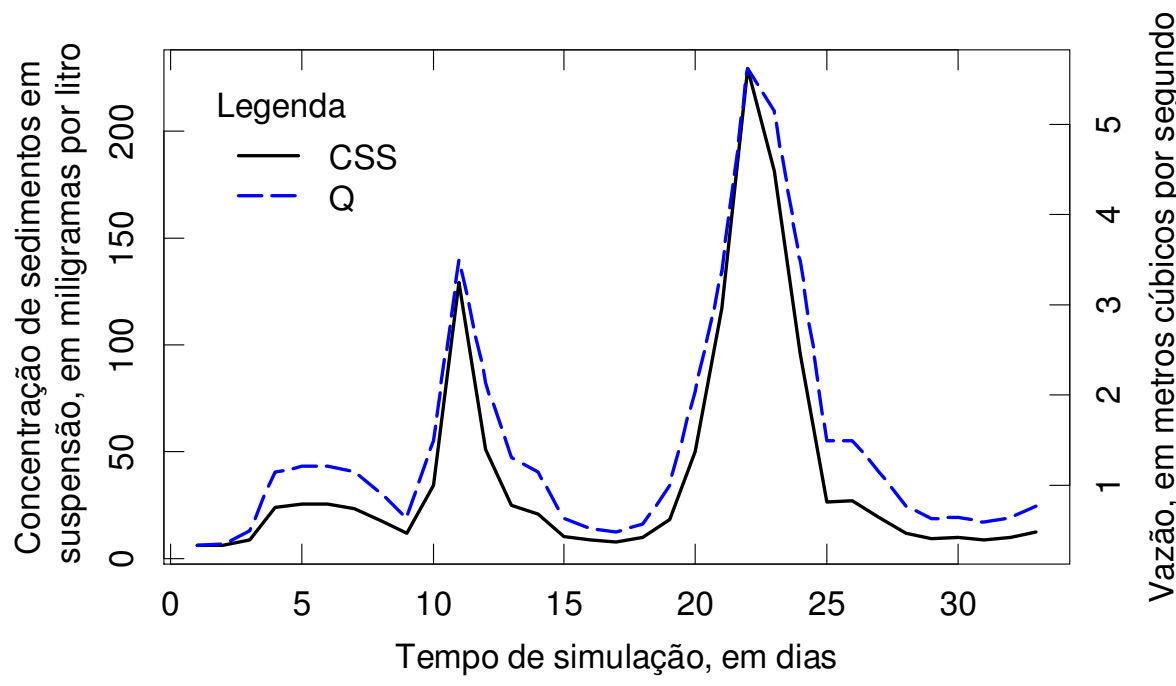

Figura 5-17 - Sedimentograma modelado durante a passagem de uma onda de cheia no posto fluvissedimentométrico T1.

${ }^{14}$ Segundo Minella, Merten e Magnago (2011), efeito de histerese é o aparecimento de um atraso na evolução dinâmica do hidrograma e do sedimentograma, durante a passagem de uma onda de cheia. Esse não sincronismo de fase implica que, para uma mesma vazão, a concentração de sedimentos em suspensão pode ser diferente nos ramos ascendente e descendente do hidrograma, para um mesmo evento. 
As simulações, a partir das funções de capacidade de transporte de sedimentos de Yang, Engelund-Hansen e Ackers-White, resultaram em erro de processamento, por ajuste não realístico do leito em uma ou mais seções transversais (Figura 5-18). Caber observar que os parâmetros hidráulicos dos canais modelados (Tabela 5-7) encontraram-se fora da faixa de aplicabilidade dessas funções (Tabela 2-1).

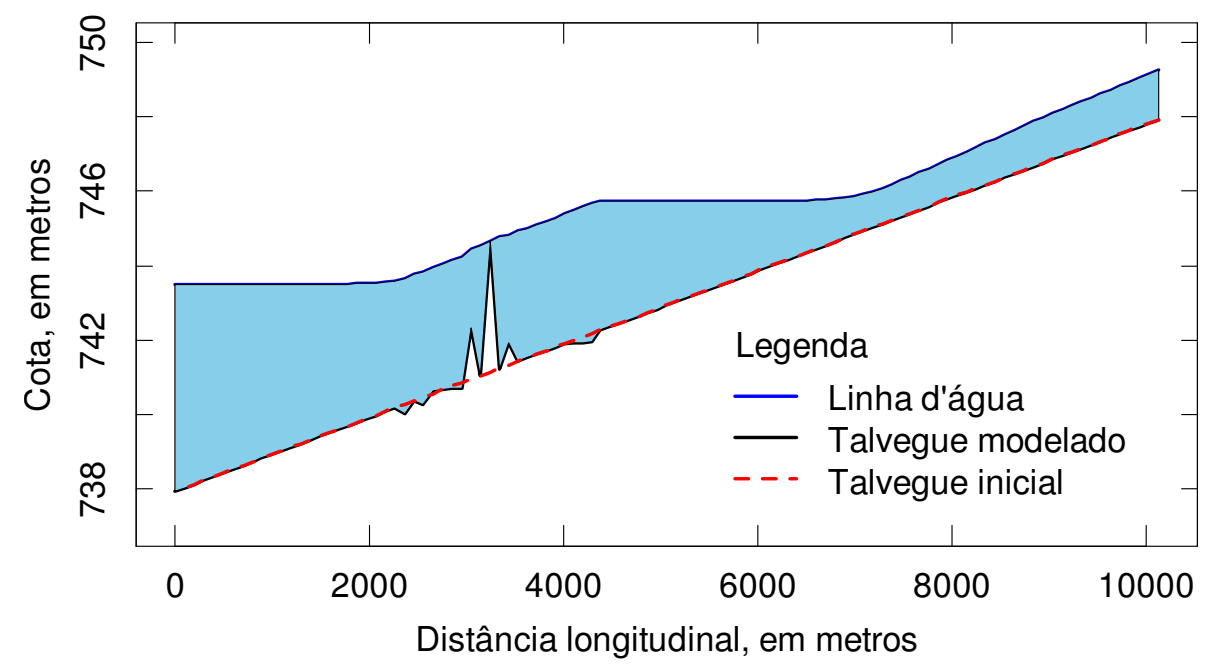

Figura 5-18 - Representação longitudinal do modelo de fundo móvel do rio Taiaçupeba Guaçu, calculado pela função de Yang, método de encouraçamento de Thomas-Copeland, exemplificando 0 ajuste não realístico do leito nas seções 3044, 3229 e 3343, para $Q=1,204 \mathrm{~m}^{3} / \mathrm{s}$ e cota do reservatório $743,50 \mathrm{~m}$.

Já a partir das funções de Laursen-Copeland e Toffaleti, o processamento foi bem sucedido (Tabela 5-9 a Tabela 5-12), à exceção da combinação da função de Laursen-Copeland com o método de encouraçamento de fundo de ThomasCopeland, que resultou em ajustes não realísticos do leito, independentemente do valor de $n$ aplicado. 
Tabela 5-9 - Análise de sensibilidade na descarga sólida total $\left(Q_{s}\right)$, agradação máxima absoluta $\left(\Delta Z_{a}\right)$ e degradação máxima absoluta do leito $\left(\Delta Z_{d}\right)$, modeladas para o rio Taiaçupeba Mirim

\begin{tabular}{|c|c|c|c|c|c|c|c|}
\hline \multirow[b]{3}{*}{$\begin{array}{l}\text { Método de } \\
\text { encouraçamento }\end{array}$} & \multirow[b]{3}{*}{$\begin{array}{l}\text { Variação } \\
\text { de } n(\%)\end{array}$} & \multicolumn{6}{|c|}{ Função } \\
\hline & & \multicolumn{3}{|c|}{ Toffaleti } & \multicolumn{3}{|c|}{ Laursen-Copeland } \\
\hline & & $Q_{S}(\mathrm{t})$ & $\Delta Z_{a}(\mathrm{~m})$ & $\Delta Z_{d}(\mathrm{~m})$ & $Q_{s}(\mathrm{t})$ & $\Delta Z_{a}(\mathrm{~m})$ & $\Delta Z_{d}(\mathrm{~m})$ \\
\hline \multirow{4}{*}{ Hirano } & 25 & $3,15 \times 10^{4}$ & 0,79 & $-0,25$ & $3,21 \times 10^{4}$ & 0,62 & $-0,25$ \\
\hline & 50 & $2,80 \times 10^{4}$ & 0,63 & $-0,25$ & $2,72 \times 10^{4}$ & 0,50 & $-0,25$ \\
\hline & 75 & $2,39 \times 10^{4}$ & 0,57 & $-0,25$ & $2,39 \times 10^{4}$ & 0,52 & $-0,25$ \\
\hline & 100 & $1,99 \times 10^{4}$ & 0,64 & $-0,25$ & $2,23 \times 10^{4}$ & 0,43 & $-0,25$ \\
\hline \multirow{4}{*}{ Thomas-Copeland } & 25 & $3,25 \times 10^{4}$ & 0,47 & $-0,25$ & \multirow{4}{*}{\multicolumn{3}{|c|}{$\begin{array}{l}\text { Erro de processamento por } \\
\text { ajuste não realístico do leito }\end{array}$}} \\
\hline & 50 & $2,86 \times 10^{4}$ & 0,39 & $-0,25$ & & & \\
\hline & 75 & $2,34 \times 10^{4}$ & 0,58 & $-0,25$ & & & \\
\hline & 100 & $1,95 \times 10^{4}$ & 0,72 & $-0,25$ & & & \\
\hline
\end{tabular}

Tabela 5-10 - Análise de sensibilidade na descarga sólida total $\left(Q_{s}\right)$, agradação máxima absoluta $\left(\Delta Z_{a}\right)$ e degradação máxima absoluta do leito $\left(\Delta Z_{d}\right)$, modeladas para o rio Balainho

\begin{tabular}{|c|c|c|c|c|c|c|c|}
\hline \multirow[b]{3}{*}{$\begin{array}{l}\text { Método de } \\
\text { encouraçamento }\end{array}$} & \multirow[b]{3}{*}{$\begin{array}{l}\text { Variação } \\
\text { de } n(\%)\end{array}$} & \multicolumn{6}{|c|}{ Função } \\
\hline & & \multicolumn{3}{|c|}{ Toffaleti } & \multicolumn{3}{|c|}{ Laursen-Copeland } \\
\hline & & $Q_{s}(\mathrm{t})$ & $\Delta Z_{a}(\mathrm{~m})$ & $\Delta Z_{d}(\mathrm{~m})$ & $Q_{s}(\mathrm{t})$ & $\Delta Z_{a}(\mathrm{~m})$ & $\Delta Z_{d}(\mathrm{~m})$ \\
\hline \multirow{4}{*}{ Hirano } & 25 & $1,48 \times 10^{5}$ & 1,74 & $-0,25$ & $2,72 \times 10^{5}$ & 1,44 & $-0,25$ \\
\hline & 50 & $5,57 \times 10^{4}$ & 2,16 & $-0,25$ & $1,88 \times 10^{5}$ & 1,50 & $-0,23$ \\
\hline & 75 & $3,29 \times 10^{4}$ & 1,99 & $-0,25$ & $1,52 \times 10^{5}$ & 1,75 & $-0,06$ \\
\hline & 100 & $2,27 \times 10^{4}$ & 1,87 & $-0,02$ & $1,27 \times 10^{5}$ & 1,63 & 0,00 \\
\hline \multirow{4}{*}{ Thomas-Copeland } & 25 & $1,24 \times 10^{5}$ & 1,67 & $-0,25$ & \multirow{4}{*}{\multicolumn{3}{|c|}{$\begin{array}{l}\text { Erro de processamento por } \\
\text { ajuste não realístico do leito }\end{array}$}} \\
\hline & 50 & $5,01 \times 10^{4}$ & 1,89 & $-0,25$ & & & \\
\hline & 75 & $3,13 \times 10^{4}$ & 1,90 & $-0,04$ & & & \\
\hline & 100 & $2,42 \times 10^{4}$ & 1,83 & $-0,04$ & & & \\
\hline
\end{tabular}

Tabela 5-11 - Análise de sensibilidade na descarga sólida total $\left(Q_{s}\right)$, agradação máxima absoluta $\left(\Delta Z_{a}\right)$ e degradação máxima absoluta do leito $\left(\Delta Z_{d}\right)$, modeladas para o rio Taiaçupeba Guaçu

\begin{tabular}{llcccccc}
\hline & & \multicolumn{5}{c}{ Função } \\
\cline { 3 - 8 } & & \multicolumn{3}{c}{ Toffaleti } & \multicolumn{3}{c}{ Laursen-Copeland } \\
\hline Método de & $\begin{array}{l}\text { Variação } \\
\text { encouraçamento }\end{array}$ & \multirow{2}{*}{$Q_{s}(\mathrm{t})$} & $\Delta Z_{a}(\mathrm{~m})$ & $\Delta Z_{d}(\mathrm{~m})$ & $Q_{s}(\mathrm{t})$ & $\Delta Z_{a}(\mathrm{~m})$ & $\Delta Z_{d}(\mathrm{~m})$ \\
\hline \multirow{4}{*}{ Hirano } & 25 & $1,27 \times 10^{5}$ & 1,80 & $-0,25$ & $1,36 \times 10^{5}$ & 1,20 & $-0,25$ \\
& 50 & $1,09 \times 10^{5}$ & 0,42 & $-0,25$ & $1,08 \times 10^{5}$ & 1,04 & $-0,25$ \\
& 75 & $8,23 \times 10^{4}$ & 0,35 & $-0,25$ & $9,73 \times 10^{4}$ & 0,27 & $-0,25$ \\
& 100 & $6,93 \times 10^{4}$ & 0,38 & $-0,25$ & $9,32 \times 10^{4}$ & 0,16 & $-0,25$ \\
\hline \multirow{4}{*}{ Thomas-Copeland } & 25 & $1,20 \times 10^{5}$ & 0,57 & $-0,25$ & & & \\
& 50 & $9,98 \times 10^{4}$ & 0,63 & $-0,25$ & Erro de processamento por \\
& 75 & $6,53 \times 10^{4}$ & 0,30 & $-0,25$ & ajuste não realístico do leito \\
& 100 & $5,37 \times 10^{4}$ & 0,16 & $-0,25$ & & & \\
\hline
\end{tabular}


Tabela 5-12 - Análise de sensibilidade na descarga sólida total $\left(Q_{s}\right)$, agradação máxima absoluta $\left(\Delta Z_{a}\right)$ e degradação máxima absoluta do leito $\left(\Delta Z_{d}\right)$, modeladas para o canal JU-TA

\begin{tabular}{llcccccc}
\hline & & \multicolumn{5}{c}{ Função } \\
\cline { 3 - 8 } & & \multicolumn{3}{c}{ Toffaleti } & \multicolumn{3}{c}{ Laursen-Copeland } \\
\hline Método de & $\begin{array}{l}\text { Variação } \\
\text { encouraçamento }\end{array}$ & \multirow{2}{*}{$Q_{s}(\mathrm{t})$} & $\Delta Z_{a}(\mathrm{~m})$ & $\Delta Z_{d}(\mathrm{~m})$ & $Q_{s}(\mathrm{t})$ & $\Delta Z_{a}(\mathrm{~m})$ & $\Delta Z_{d}(\mathrm{~m})$ \\
\hline \multirow{3}{*}{ Hirano } & 25 & $8,71 \times 10^{4}$ & - & $-0,25$ & $8,70 \times 10^{4}$ & - & $-0,25$ \\
& 50 & $7,52 \times 10^{4}$ & 0,38 & $-0,25$ & $7,40 \times 10^{4}$ & 0,25 & $-0,22$ \\
& 75 & $6,25 \times 10^{4}$ & 0,28 & $-0,20$ & $6,83 \times 10^{4}$ & 0,06 & $-0,17$ \\
& 100 & $5,63 \times 10^{4}$ & 0,23 & $-0,21$ & $6,93 \times 10^{4}$ & 0,06 & $-0,18$ \\
\hline \multirow{4}{*}{ Thomas-Copeland } & 25 & $8,69 \times 10^{4}$ & 0,00 & $-0,25$ & & & \\
& 50 & $7,38 \times 10^{4}$ & 0,59 & $-0,23$ & Erro de processamento por \\
& 75 & $5,63 \times 10^{4}$ & 0,11 & $-0,13$ & ajuste não realístico do leito \\
& 100 & $4,86 \times 10^{4}$ & 0,42 & $-0,17$ & & & \\
\hline
\end{tabular}

Alternativamente, o modelo de fundo móvel foi simulado com carga de sedimento em equilíbrio, definida como condição de contorno de montante, de modo a utilizar a capacidade de transporte como entrada do sistema, em lugar das curvas de sedimento estimadas. Contudo, o modelo mostrou-se instável sob essa condição (Figura 5-19), não atingindo um equilíbrio dinâmico.

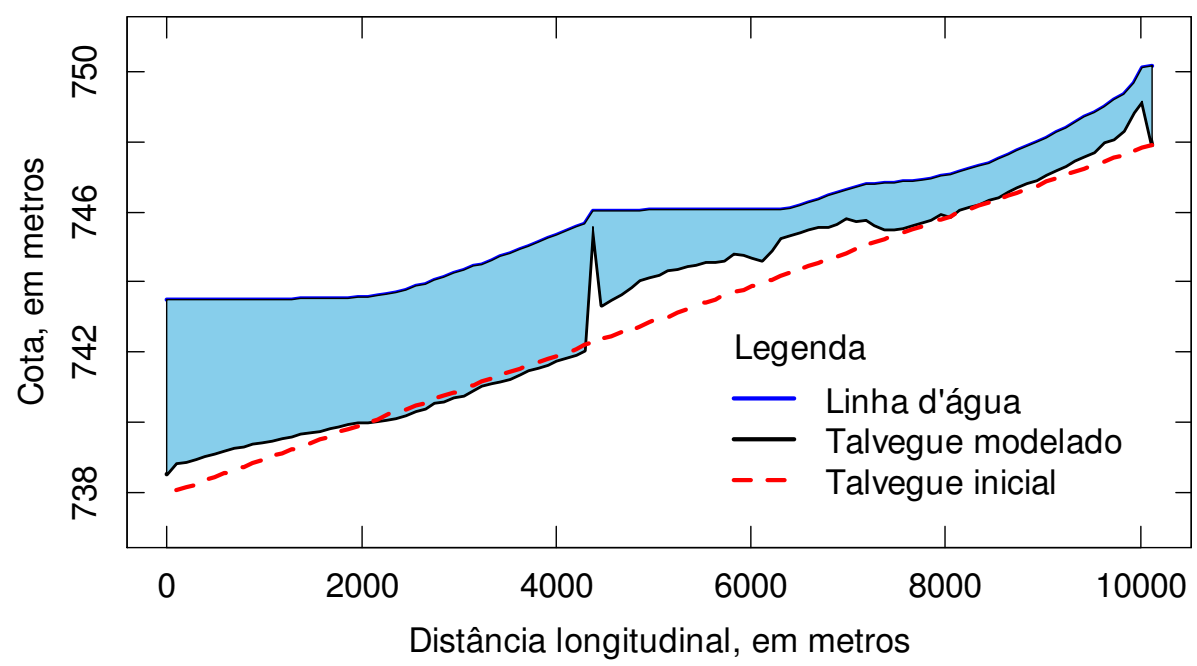

Figura 5-19 - Representação longitudinal do modelo de fundo móvel do rio Taiaçupeba Guaçu, calculado pela função de Laursen-Copeland, método de encouraçamento de Hirano, exemplificando a ausência de equilíbrio dinâmico do sistema fluvial para carga de equilíbrio a montante, $Q=0,950 \mathrm{~m}^{3} / \mathrm{s}$ e cota do reservatório $743,50 \mathrm{~m}$. 
Dessa forma, utilizando-se as curvas de sedimento estimadas como condição de contorno de montante, as combinações que resultaram na condição de maior estabilidade dinâmica foram Toffaleti, Thomas-Copeland e $0,5 n$ para o rio Taiaçupeba Mirim (Figura 5-20), Laursen-Copeland, Hirano e 0,25n para o rio Balainho (Figura 5-21) e Laursen-Copeland, Hirano e 1,0n para o rio Taiaçupeba Guaçu (Figura 5-22) e Canal JU-TA (Figura 5-23).

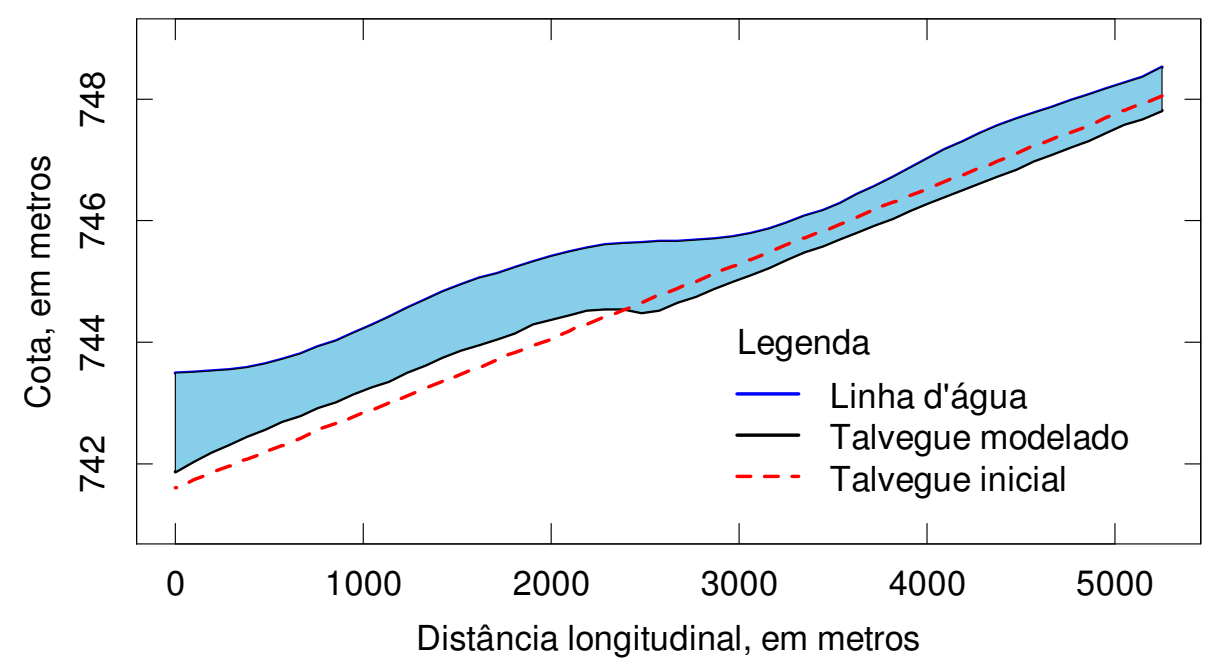

Figura 5-20 - Representação longitudinal do modelo de fundo móvel do rio Taiaçupeba Mirim, calculado pela função de Toffaleti, método de encouraçamento de Thomas-Copeland, $0,5 n$, para $Q=1,5 \mathrm{~m}^{3} / \mathrm{s}$ e cota do reservatório $743,50 \mathrm{~m}$.

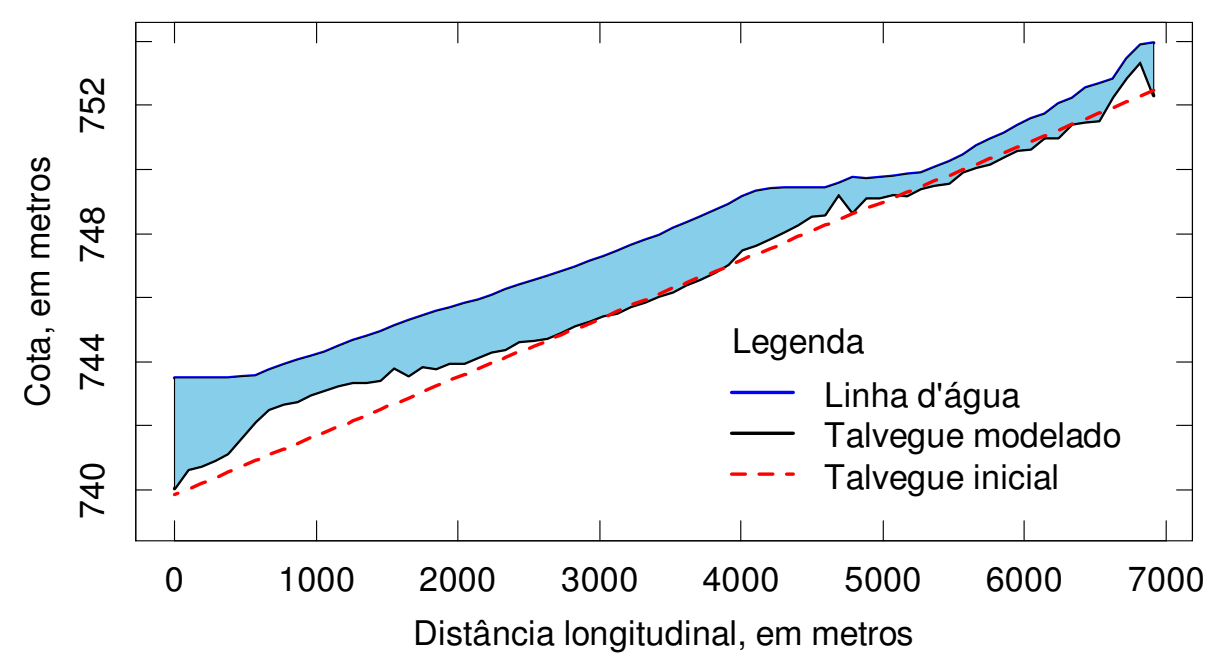

Figura 5-21 - Representação longitudinal do modelo de fundo móvel do rio Balainho, calculado pela função de Laursen-Copeland, método de encouraçamento de Hirano, $0,25 \mathrm{n}$, para $Q=1,634 \mathrm{~m}^{3} / \mathrm{s}$ e cota do reservatório $743,50 \mathrm{~m}$. 


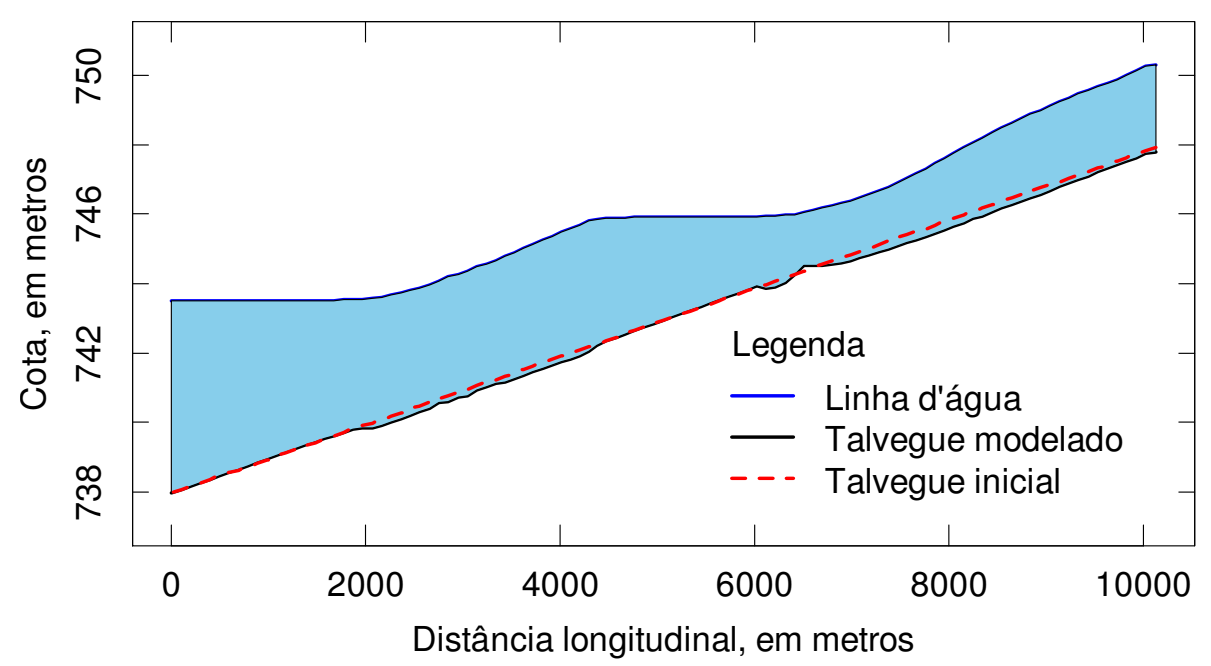

Figura 5-22 - Representação longitudinal do modelo de fundo móvel do rio Taiaçupeba Guaçu, calculado pela função de Laursen-Copeland, método de encouraçamento de Hirano, $1,0 \mathrm{n}$, para $Q=4,724 \mathrm{~m}^{3} / \mathrm{s}$ e cota do reservatório $743,50 \mathrm{~m}$.

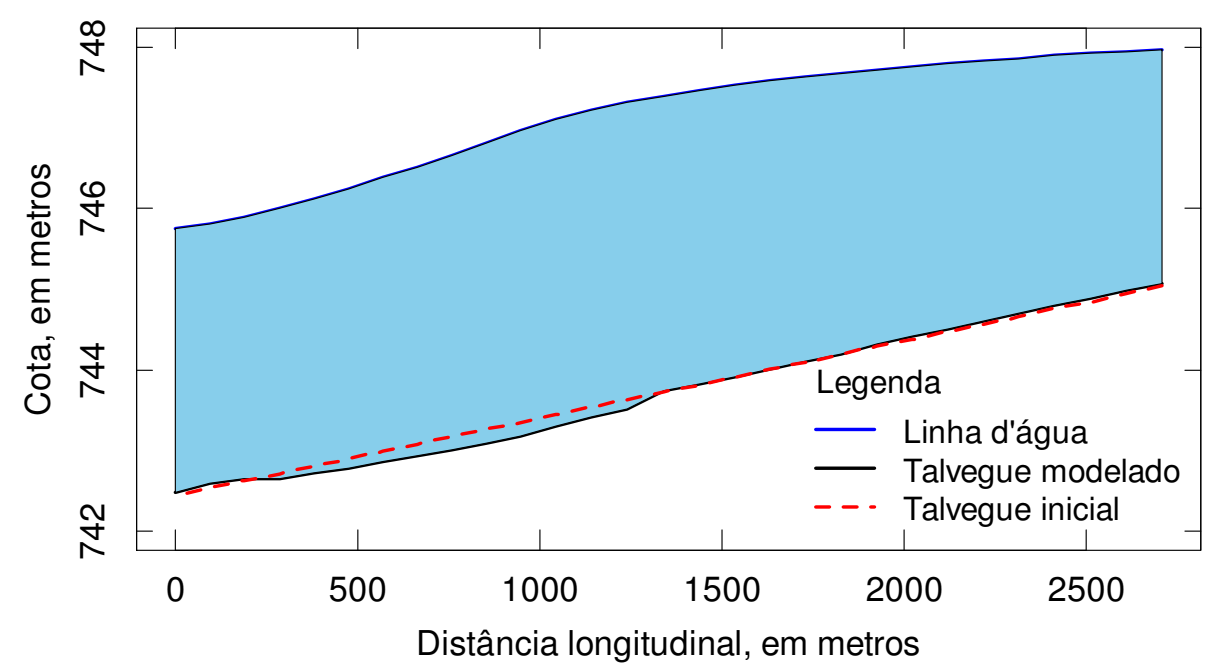

Figura 5-23 - Representação longitudinal do modelo de fundo móvel do canal JU-TA, calculado pela função de Laursen-Copeland, método de encouraçamento de Hirano, $1,0 n$, para $Q=8,452 \mathrm{~m}^{3} / \mathrm{s}$.

No caso dos rios Taiaçupeba Mirim e Balainho, a análise de sensibilidade (Tabela 5-9 e Tabela 5-10) indicou que os valores de n, preliminarmente ajustados, induziram instabilidades no leito e depósitos excessivos. Ainda que a redução sugerida $(0,5 n$ e $0,25 n$, respectivamente) afaste a solução da linha d'água de sua otimização, ela promoveu um melhor equilíbrio dinâmico nesses canais. Além disso, os valores finais de $n$ apresentam-se mais coerentes à ordem de grandeza recomendada pela literatura, restringindo os valores mais altos às seções situadas em zona de remanso ou confluência (Tabela 5-13). 
Tabela 5-13 - Coeficientes $n$ recomendados para ajuste final do modelo de transporte de sedimentos. São comparadas as alturas da coluna d'água medida $(Y)$ e modelada $\left(Y^{\prime}\right)$ para o ajuste

\begin{tabular}{lcccc}
\hline Rio & Seção & $\boldsymbol{n}$ de Manning & $\mathbf{Y}$ & $\mathbf{Y}^{\prime}$ \\
\hline \multirow{4}{*}{ Taiaçupeba Mirim } & 5250 & 0,03 & 1,3 & 0,94 \\
& 5050 & 0,035 & 1,3 & 0,94 \\
& 4188 & 0,035 & 1,5 & 1,03 \\
& 3350 & 0,025 & 1,2 & 0,79 \\
& 2575 & 0,02 & 1,7 & 1,10 \\
Balainho & 1134 & 0,125 & 2,0 & 1,40 \\
& 6909 & 0,023 & 0,7 & 0,35 \\
& 6429 & 0,025 & 0,9 & 0,53 \\
Taiaçupeba Guaçu & 4399 & 0,05 & 1,4 & 0,59 \\
& 4006 & 0,14 & 2,1 & 1,12 \\
& 568 & 0,14 & 2,0 & 1,71 \\
\hline \multirow{2}{*}{ Canal JU-TA } & 10122 & 0,14 & 1,6 & 1,54 \\
& 8045 & 0,15 & 1,2 & 1,26 \\
& 5826 & 0,02 & 1,4 & 1,53 \\
& 3143 & 0,07 & 3,1 & 2,96 \\
\hline
\end{tabular}

A descarga sólida total aportada no reservatório, em 41 anos de simulação, resultou em $393.633,37 \mathrm{t}$, equivalente a $26,3 \mathrm{t} / \mathrm{d}$, ou $430.738,92 \mathrm{~m}^{3}$ em volume ${ }^{15}$. O transporte de sedimentos de arrasto representou aproximadamente $4 \%$ do transporte total no rio Taiaçupeba Mirim e $1 \%$ nos rios Balainho e Taiaçupeba Guaçu. De fato, o número de Rouse ao longo dos rios Balainho e Taiaçupeba Guaçu e do Canal JU-TA (Figura 5-24), apresentou-se predominantemente abaixo de 2,5, indicando que o transporte por suspensão dominou o movimento de sedimentos. Em termos de representação por classe granulométrica, a descarga sólida total foi composta por $13 \%$ de argila, $84 \%$ de silte e $3 \%$ de areia (Tabela 5-14).

${ }^{15}$ Os pesos específicos adotados foram de $480 \mathrm{~kg} / \mathrm{m}^{3}$ para argila, $1.041 \mathrm{~kg} / \mathrm{m}^{3}$ para silte e $1.489 \mathrm{~kg} / \mathrm{m}^{3}$ para areia. 


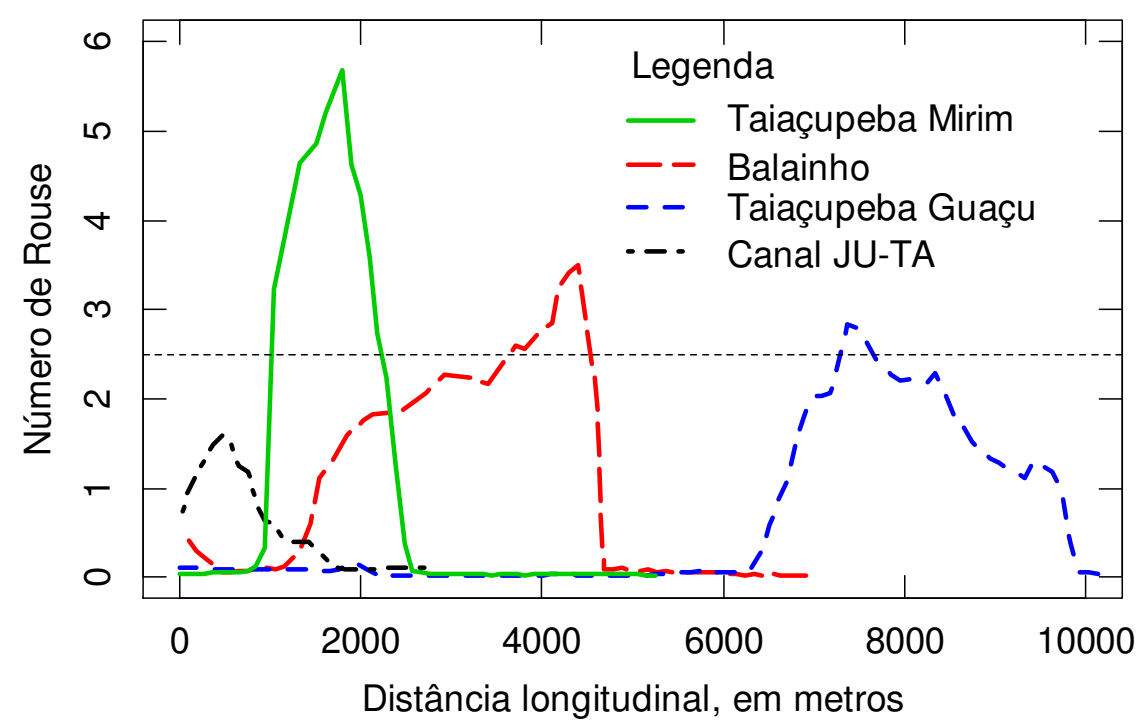

Figura 5-24 - Distribuição longitudinal do número de Rouse, após o modelo atingir o equilíbrio dinâmico (701 dias do início da simulação), calculado a partir da velocidade de queda média das partículas e da velocidade de atrito de cada seção.

Tabela 5-14 - Descarga sólida total modelada, por classe granulométrica, segundo classificação da American Geophysical Union

\begin{tabular}{|c|c|c|c|c|c|}
\hline & & & \multicolumn{3}{|c|}{ Posto fluvissedimentométrico } \\
\hline & & & $\begin{array}{l}\text { Taiaçupeba } \\
\text { Mirim }\end{array}$ & Balainho & $\begin{array}{c}\text { Taiaçupeba } \\
\text { Guaçu }\end{array}$ \\
\hline \multicolumn{3}{|c|}{ Descarga sólida total (t) } & $28.574,47$ & $271.901,72$ & $93.157,18$ \\
\hline \multirow{11}{*}{ 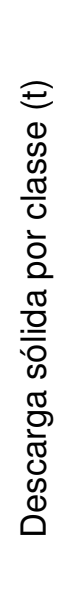 } & Argila & $0,002 \mathrm{~mm}-0,004 \mathrm{~mm}$ & $2.602,54$ & $32.834,82$ & $15.399,93$ \\
\hline & Silte muito fino & $0,004 \mathrm{~mm}-0,008 \mathrm{~mm}$ & $4.590,06$ & $61.512,94$ & $23.639,64$ \\
\hline & Silte fino & $0,008 \mathrm{~mm}-0,016 \mathrm{~mm}$ & $9.020,14$ & $99.982,84$ & $29.370,10$ \\
\hline & Silte médio & $0,016 \mathrm{~mm}-0,032 \mathrm{~mm}$ & $7.556,75$ & $54.060,36$ & $18.428,44$ \\
\hline & Silte grosso & $0,032 \mathrm{~mm}-0,0625 \mathrm{~mm}$ & $3.530,18$ & $14.050,29$ & $4.844,96$ \\
\hline & Areia muito fina & $0,0625 \mathrm{~mm}-0,125 \mathrm{~mm}$ & 689,16 & $4.799,65$ & 940,12 \\
\hline & Areia fina & $0,125 \mathrm{~mm}-0,25 \mathrm{~mm}$ & 400,50 & $3.045,09$ & 158,27 \\
\hline & Areia média & $0,25 \mathrm{~mm}-0,5 \mathrm{~mm}$ & 151,32 & $1.360,28$ & 283,25 \\
\hline & Areia grossa & $0,5 \mathrm{~mm}-1 \mathrm{~mm}$ & 30,42 & 236,38 & 70,30 \\
\hline & Areia muito grossa & $1 \mathrm{~mm}-2 \mathrm{~mm}$ & 2,66 & 17,22 & 19,55 \\
\hline & Cascalho & $>2 \mathrm{~mm}$ & 0,76 & 1,86 & 2,62 \\
\hline
\end{tabular}




\section{DISCUSSÃO}

A seguir, são discutidas as limitações do modelo desenvolvido, recomendações ao método proposto e tecnologias aplicáveis à trabalhos futuros.

\subsection{CARACTERIZAÇÃO DO TRANSPORTE DE SEDIMENTOS}

A estiagem histórica, ocorrida durante a coleta de dados, restringiu a amplitude de vazões nos eventos amostrados (Figura 5-2 a Figura 5-4). Do ponto de vista da engenharia, apesar de atestada a significância estatística das curvas de sedimento (Figura 5-8 a Figura 5-10), há uma ampla faixa de vazões para as quais o transporte de sedimentos não foi caracterizado (Figura 5-2 a Figura 5-4), importante para a acurácia do modelo. Contudo, do ponto de vista científico, o regime foi caracterizado sob uma condição rara de seca, resultado inédito para a pesquisa hidrossedimentológica e potencialmente útil para identificar futuras condições adversas na bacia do Taiaçupeba.

Já do ponto de vista prático, o monitoramento nessas condições foi útil para evidenciar a complexidade operacional de monitorar rios de pequeno porte. Apesar de o método prever a amostragem baseada em evento, a passagem das ondas de cheia na bacia é rápida, o que dificultou a caracterização do regime de transporte de sedimentos por medições discretas.

Além disso, a descarga sólida total simulada $\left(0,4 \mathrm{hm}^{3}\right)$, a partir de curvas de sedimentos que foram representativas de um período seco, subestimou a estimativa de assoreamento do reservatório $\left(5 \mathrm{hm}^{3}\right)$. Apesar do rigoroso planejamento de amostragem e tratamento estatístico dos dados, com uma média de 20 amostras por posto fluvissedimentométrico, as condições climáticas sobressaíram nos resultados.

Especificamente para o posto $\mathrm{T} 1$, notou-se uma subestimação do transporte de suspensão quando comparado ao posto T2. A CSS máxima naquele posto foi $30 \%$ menor que nesse último (Tabela 5-1), para uma vazão 4 vezes maior, amostrados sob o mesmo evento. Sugere-se a realocação da seção de amostragem de $T 1$, considerando-se que a escolha do ponto a jusante das galerias foi inadequada. Há uma travessia, localizada $150 \mathrm{~m}$ a jusante do posto $\mathrm{T} 1$, com potencial para futuros estudos nesse canal. 
A seção escolhida para o posto T5 mostrou-se igualmente inadequada. Em algumas campanhas, foram observadas baixas velocidades de escoamento, em função dos efeitos da bacia de dissipação de energia, a jusante do posto. Ainda que tenha sido possível coletar as amostras de sedimento, devido à diferença de pressão hidrostática interna e externa ao amostrador, quando submerso, algumas amostragens não foram isocinéticas, produzindo resultados não comparáveis entre si. Também foi observada uma tendência de assoreamento do canal extravasor da tomada d'água TA-2, por um material fino, de difícil mobilização, que pode superestimar as descargas sólidas e, consequentemente, o regime de transporte de sedimentos que a barragem impõe a jusante. Sugere-se que futuros estudos avaliem a possibilidade de instalação de travessia temporária no trecho fluvial do rio Taiaçupeba Açu, onde os efeitos de dissipação de energia da bacia de jusante do reservatório sejam desprezíveis e o regime de transporte de sedimentos seja mais representativo.

\subsection{MODELAGEM DO TRANSPORTE DE SEDIMENTOS}

Conforme discutido anteriormente, a caracterização de rios de pequeno porte é complexa, de modo que pequenos erros de medição, ou pequenas variações na geometria de seções, podem ser percentualmente significativos. Nesse contexto, algumas simplificações adotadas no levantamento das seções transversais contribuíram para os altos valores do coeficiente $n$ no ajuste preliminar do modelo de escoamento em regime permanente, tais como:

- o levantamento pouco adensado de seções, podendo haver estrangulamentos ou alargamentos importantes não representados;

- o uso da declividade média, única para todo o segmento dos canais, descaracterizando mudanças locais importantes ao perfil longitudinal;

- a não representação de singularidades, como pilares de pontes e galerias.

Sobre essa última, sua influência foi avaliada no segmento superior do rio Taiaçupeba Guaçu, a montante da confluência com o canal JU-TA. Nesse trecho, o rio é interceptado por uma galeria (coordenadas UTM $371.753 \mathrm{~m}$ e $7.383 .073 \mathrm{~m}$ ), composta por dois tubos circulares de concreto, com $2 \mathrm{~m}$ de diâmetro cada, 42,6 m 
de comprimento, declividade de $2,5 \%$ e coeficiente $n$ de 0,015 , valor de literatura para concreto em condições regulares, obtido em Porto (2006). No entanto, sua inclusão no modelo de escoamento representou uma influência pequena no resultado da linha d'água (Figura 6-1), rebaixando-a entre $5 \mathrm{~cm}$ e $1 \mathrm{~cm}$, desde a seção da galeria (8055) até aproximadamente $600 \mathrm{~m}$ a montante. Por esse motivo, entende-se que essa simplificação apresenta baixo grau de influência.

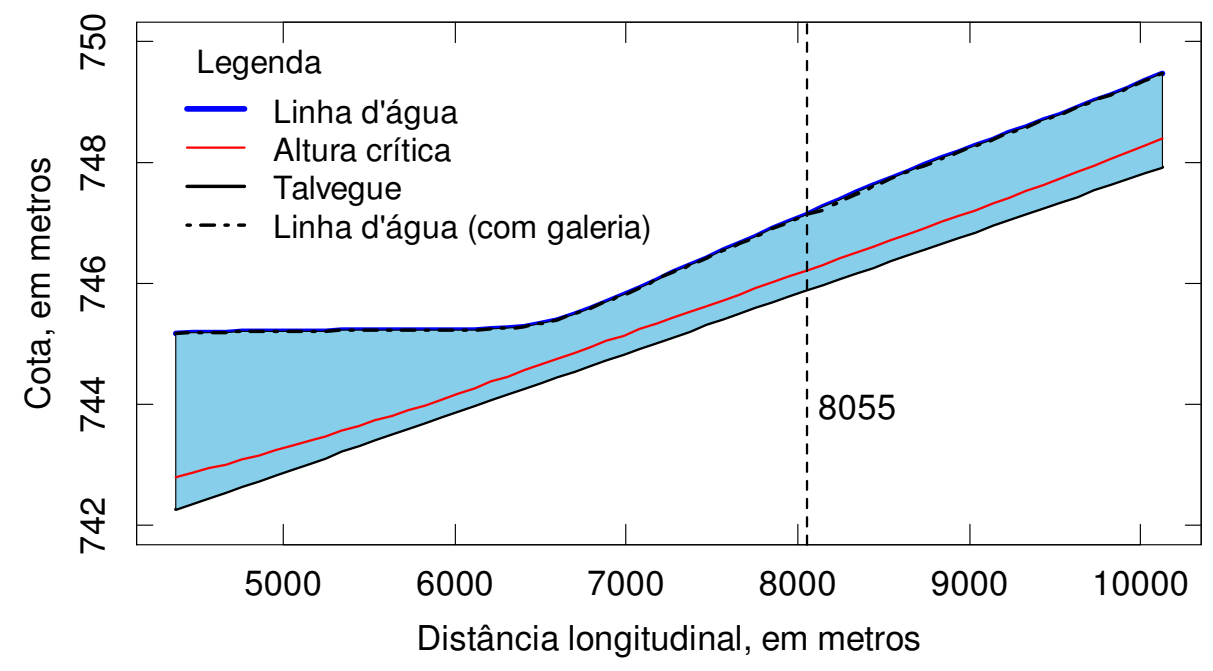

Figura 6-1 - Representação longitudinal do modelo de escoamento do rio Taiaçupeba Guaçu, segmento superior, para $Q=1,587 \mathrm{~m}^{3} / \mathrm{s}$, apresentando a linha d'água gerada a partir da inserção da singularidade na seção 8055 .

Considerando-se que simplificações metodológicas são, em geral, necessárias para adequação dos recursos disponíveis aos projetos de pesquisa, a análise de sensibilidade das funções de capacidade de transporte e dos métodos de encouraçamento de fundo, frente a frações do coeficiente $n$, foi eficaz para parametrização do modelo e determinação de uma solução dinamicamente estável.

Ainda assim, alguns segmentos do rio Taiaçupeba Mirim apresentaram erosão pronunciada do leito ao final da simulação (Figura 5-20). Em virtude da ausência de amostras de sedimentos associadas a eventos de alta descarga, a entrada do modelo previa apenas sedimentos finos e em baixas concentrações, não havendo material para reposição do leito. Dessa forma, foi observado um forte encouraçamento, permanecendo ao final da simulação apenas partículas mais grosseiras no leito, evidenciado pelo incremento do parâmetro $d_{50}$ e pelo desaparecimento da camada inativa do leito entre as seções 2.575 e 5.250 (Figura 6-2). Nesses casos, a degradação do leito foi limitada unicamente pela imposição da 
profundidade máxima de erosão de $0,25 \mathrm{~m}$.

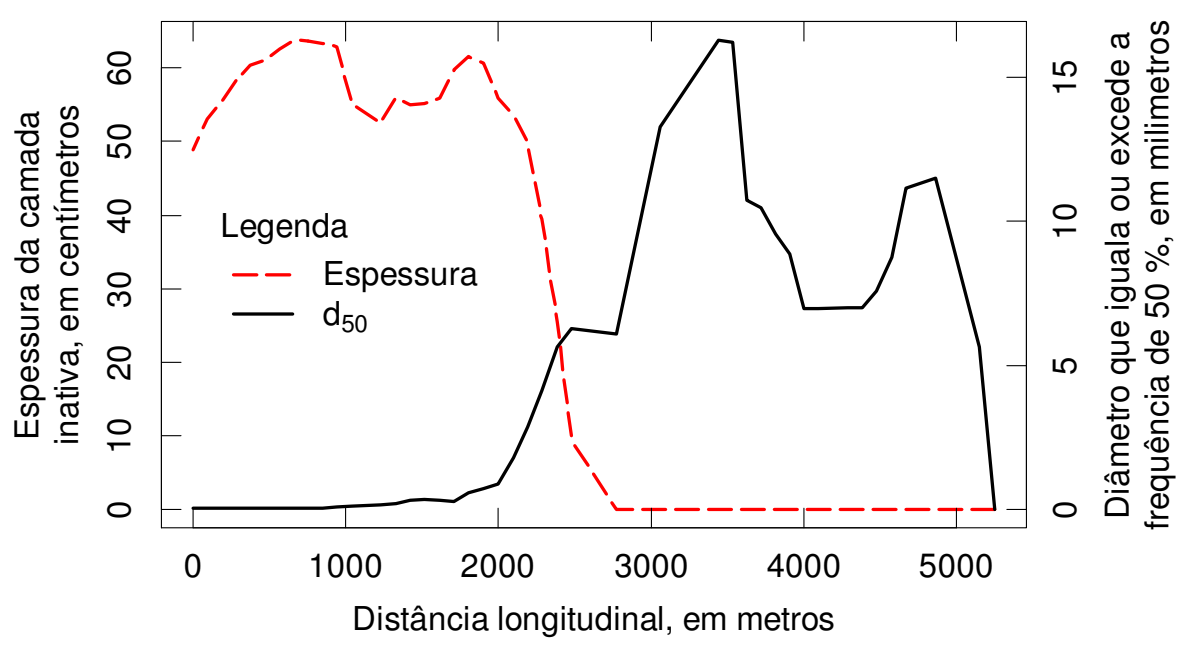

Figura 6-2 - Distribuição longitudinal do parâmetro $d_{50}$ e da espessura da camada inativa do leito, para o rio Taiaçupeba Mirim, ao final da simulação de fundo móvel, para a condição de $Q=0,468$ m³/s.

O rio Balainho, em contrapartida, apresentou volumes de assoreamento excessivos em seções com aumento brusco do coeficiente $n$ (principalmente a jusante da seção 4.399), o que impôs uma desaceleração do escoamento e um aumento significativo da tensão de cisalhamento no leito, favorecendo a deposição e restringindo o transporte de arrasto e a resuspensão das partículas já depositadas (Figura 6-3).

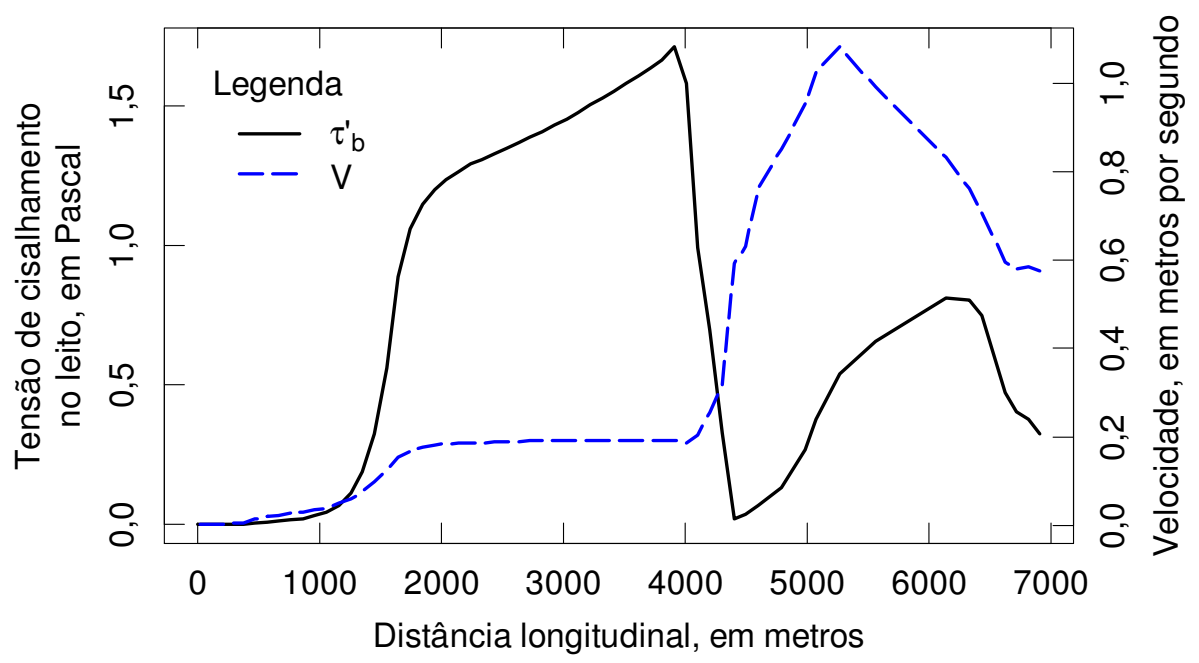

Figura 6-3 - Distribuição longitudinal da tensão de cisalhamento do leito $\left(\tau_{b}^{\prime}\right)$ e da velocidade média do escoamento $(V)$, no rio Balainho, ao final da simulação de fundo móvel, para a condição de $Q=0,355 \mathrm{~m}^{3} / \mathrm{s}$. 
Além disso, o perfil modelado de concentração dos sedimentos em suspensão, ao longo dos canais, foi predominantemente decrescente (Figura 6-4). Esse resultado possui significado físico, uma vez que há uma única entrada de descarga sólida e, à medida que o escoamento desacelera, com a aproximação da zona de remanso, as forças gravitacionais excedem a componente vertical das forças de turbulência e as partículas se depositam. Contudo, pelo forte encouraçamento observado, é possível que o decaimento da concentração também seja consequência do trapeamento de partículas finas no leito, situação que pode ser avaliada em trabalhos futuros.

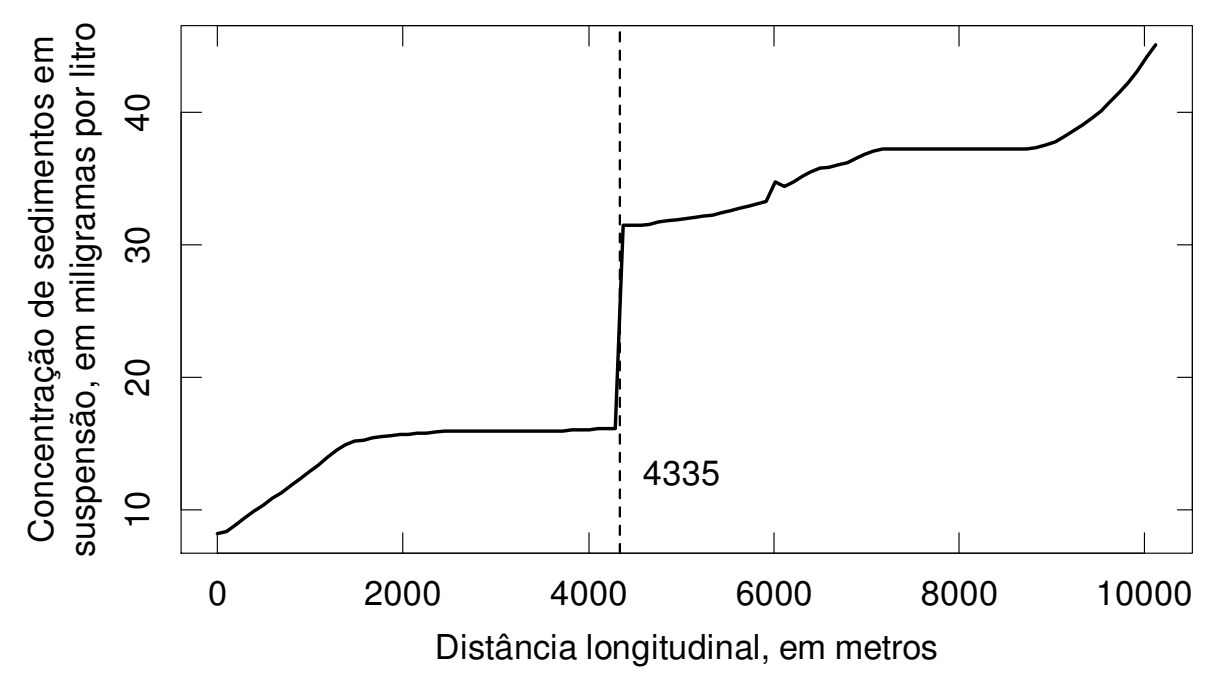

Figura 6-4 - Distribuição longitudinal da concentração de sedimentos em suspensão no rio Taiaçupeba Guaçu, ao final da simulação de fundo móvel, para a condição de $Q=13,871 \mathrm{~m}^{3} / \mathrm{s}$. A dissolução brusca do sedimento em suspensão, na seção 4.335, é função da contribuição do canal JU-TA, com baixa concentração de sedimentos em suspensão.

\subsection{TECNOLOGIAS APLICÁVEIS}

Demonstrada a importância da representatividade dos dados fluvissedimentométricos, particularmente em bacias pequenas onde a passagem de ondas de cheia é rápida e o transporte de sedimentos restrito a poucos eventos durante um ciclo hidrológico, configura-se a necessidade do monitoramento contínuo.

Nesse sentido, sensores ópticos, como os turbidímetros ou transdutores acústicos, como os Acoustic Doppler Velocity Meters (ADVM) podem ser instalados em estações fluviométricas, em associação a medidores de nível, para obtenção de 
variáveis diretamente correlacionáveis à CSS, conforme experimentos de Ellison et al. (2013) e Groten et al. (2016). No primeiro caso, a variável independente é a turbidez, resultado da atenuação da luz devido à absorção pelo sedimento em suspensão; no segundo, o retroespalhamento do sinal acústico, cujo retorno de sinal é lido em função do efeito Doppler sobre o sedimento em movimento na fase líquida. Essas técnicas têm demonstrado resultados promissores na obtenção de registros contínuos de descarga sólida, com alta acurácia e resolução temporal, conforme demonstrado por Levesque e Oberg (2012), Landers et al. (2016) e Topping e Wright (2016). A presença de telemetria, com transmissão dos dados em tempo real, melhora também a qualidade do planejamento das campanhas baseadas em eventos, condicionando-as às condições de escoamento desejadas.

Outro fator que pode contribuir com o aumento da representatividade dos dados é o emprego de tecnologias que tornem mais ágeis as medições, uma vez que as condições de escoamento mudam rapidamente. Nesse sentido, os Acoustic Doppler Current Profiler (ADCP) são capazes de perfilar, de forma dinâmica, as velocidades instantâneas ao longo da seção transversal, e sua acurácia e produtividade são superiores à do molinete mecânico, segundo Mueller et al. (2013).

Além disso, ADCPs têm sido aplicados em levantamentos batimétricos, como apresentado por Wernly et al. (2016), e na discretização do perfil vertical de concentração de sedimentos em suspensão, conforme discutido por Landers et al. (2016). Esse assunto não foi abordado nesta pesquisa, mas tem potencial de aplicação como um parâmetro adicional de calibração da função de capacidade de transporte de Toffaleti, que subdivide a coluna d'água em zonas verticais.

Contudo, a aplicação do ADCP no sistema fluvial Taiaçupeba pode ser inviável, em função das pequenas profundidades dos canais. Seu uso pode ser substituído pelo Acoustic Doppler Velocimeter (ADV), equipamento que opera sob os mesmos princípios do efeito Doppler, porém projetado para medições a vau.

No que se refere às tecnologias para levantamento topográfico, a solução de mapeamento utilizada mostrou-se suficientemente acurada e produtiva, em função do longo alcance do sensor de distância (aproximadamente $1.000 \mathrm{~m}$ ) e do sensor de 
inclinação triaxial digital, que dispensou a necessidade de calagem ${ }^{16}$ do equipamento. Disso decorre que sua resolução $\left(0,1^{\circ} \mathrm{em}\right.$ inclinação e $0,1 \mathrm{~m}$ em distância) foi suficiente para a escala do estudo. Contudo, avanços recentes no desenvolvimento de câmeras de alta resolução, instaladas em drones, pode constituir um novo marco na elaboração de Modelos Digitais de Elevação de baixo custo e larga escala, conforme apresentado por Figueiredo e Papa (2015).

Os resultados do nivelamento das seções transversais sugerem a necessidade de um maior detalhamento do perfil vertical longitudinal, em função da influência de especificidades locais na calibração do coeficiente $n$. Nesse caso, sugere-se o emprego do GNSS Real Time Kinematic (RTK), de acurácia centimétrica, que alia a tecnologia do GNSS com correções instantâneas transmitidas via rádio, por um segundo receptor, estacionado em local de referência, extensivamente discutida por Rydlund e Densmore (2012). Essa tecnologia pode trazer duas vantagens principais: a facilidade na adoção de um datum altimétrico comum a todo o levantamento, instalando-se o receptor base em uma referência de nível do reservatório; e a possibilidade de medir a declividade da linha d'água, dado o alto nível de precisão da técnica, fornecendo um dado adicional ao ajuste do coeficiente $n$.

\subsection{TRABALHOS FUTUROS}

A última fase do licenciamento ambiental da barragem de Taiaçupeba, que prevê a operação do reservatório no nível máximo normal (cota 747,21 m), é hoje pauta de discussão nos meios técnicos, acadêmicos e respectivas instâncias de gerenciamento. $O$ roteiro sistematizado nesta pesquisa poderá servir de base científica para os estudos hidrossedimentológicos que subsidiarão tal licenciamento.

Sugere-se a continuidade no desenvolvimento do modelo dos afluentes do reservatório, estendendo o monitoramento fluvissedimentométrico sob condições climáticas típicas, a fim de caracterizar tal regime de transporte de sedimentos. Além

\footnotetext{
${ }^{16}$ Calagem consiste no ajuste horizontal de um equipamento óptico, em geral realizado com apoio de níveis de bolha centrada ou tubular, a fim de assegurar que seu eixo principal esteja alinhado com o vetor de aceleração da gravidade local.
} 
disso, incorporar o reservatório como entidade geométrica na modelagem unidimensional, para elaboração de cenários futuros de descarga sólida e estimativa de vida útil. Para tanto, recomenda-se:

- instalação de uma estação telemétrica em um dos afluentes, com sensor de nível d'água e sólidos em suspensão (sensor óptico ou acústico), para monitoramento contínuo de vazão e transporte de sedimentos em suspensão, com resolução temporal adequada, visando a regionalização dos dados para as demais sub-bacias e a incorporação de dados contínuos para calibração e verificação do modelo unidimensional, com incerteza estatisticamente mensurável;

- execução de campanhas em ampla gama de condições de escoamento, em especial sob eventos de cheia, monitorados pelo acompanhamento da estação telemétrica, a fim de ampliar a representatividade das curvas de sedimento e possibilitar $o$ ajuste do coeficiente $n$ na planície de inundação;

- aplicação de tecnologias acústicas (ADCP ou ADV) na medição de vazões, a fim de agilizar as operações e aumentar a acurácia da estimativa;

- análise granulométrica sistemática de todas as amostras de sedimentos em suspensão, a fim de quantificar o transporte de areia em suspensão durante eventos de cheia e identificar possíveis contaminações da amostra por distúrbio do sedimento do leito, conforme proposto por Groten et al. (2016);

- amostragem de material de fundo e de sedimento em suspensão em duas ou mais seções adicionais, em cada canal, sob duas ou mais condições de escoamento, distintas entre si, a fim de avaliar a acurácia do modelo na representação dos perfis longitudinais de concentração;

- realocação do posto $T 1$, do rio Taiaçupeba Mirim, e T5, do canal extravasor da tomada d'água TA-2, considerados pouco representativos para a caracterização do transporte de sedimentos;

- associação de ADCP e GNSS RTK, em embarcação de pequeno porte, para levantamento batimétrico contínuo dos canais e levantamento do perfil da linha d'água; 
- avaliação do uso de drones com câmera de alta resolução para levantamento topográfico contínuo das planícies fluviais;

- execução de nivelamento de marcos notáveis ao longo dos canais, como tabuleiros de pontes e réguas limnimétricas, com receptor GNSS RTK, sob o datum altimétrico de referência do reservatório, a fim de obter leituras de cota da linha d'água em todas as campanhas de medição de vazão e colaborar, assim, com o ajuste do coeficiente $n$;

- estudos hidrológicos para sintetização de séries estocásticas de vazões diárias e calibração de modelos determinísticos de transformação chuvavazão, a fim de fornecer dados de entrada para modelos preditivos;

- testemunhagem dos sedimentos de fundo do reservatório a fim de avaliar o perfil longitudinal de distribuição das partículas, para calibração do modelo unidimensional no corpo central do lago; e

- execução de perfilagem sísmica no fundo do reservatório para quantificar o volume dos depósitos de assoreamento.

Sobretudo, entende-se que o método proposto, somado às recomendações supracitadas, constituem importante sistematização das técnicas e tecnologias de monitoramento, contribuindo assim com a pesquisa hidrossedimentológica. 


\section{CONCLUSÕES}

A modelagem unidimensional foi plena na caracterização do regime de transporte de sedimentos de longo termo, na escala da bacia do reservatório Taiaçupeba, atendendo aos objetivos propostos pela pesquisa. Quanto às funções de capacidade de transporte de sedimentos, tanto a de Laursen-Copeland, quanto a de Toffaleti, mostraram-se aplicáveis ao sistema fluvial em questão, bem como os métodos de encouraçamento de fundo de Hirano e Thomas-Copeland. Dentre elas, a combinação Laursen-Copeland e Hirano foi a que apresentou maior tendência de mobilização de sedimentos, resultando em maiores descargas sólidas simuladas.

Para a continuidade dos estudos, os coeficientes $n$ de Manning apresentados devem ser continuamente reajustados, à medida que novas medições forem realizadas, incorporando maior acurácia na sua estimativa. Por ter sido calibrado com dados obtidos em condições climáticas extremas de estiagem, considera-se o modelo como preliminar, de modo que a ampliação dos dados fluvissedimentométricos e novos ajustes nos parâmetros recomendados poderá proporcionar maior acurácia também na estimativa das descargas sólidas.

Contudo, o monitoramento durante um período de seca histórica foi salutar ao desenvolvimento do estudo, produzindo curvas de sedimento características para esse período, inéditas, e que podem ser úteis para identificar e gerir futuras condições adversas na bacia do Taiaçupeba. Sobretudo, ressaltou a importância da representatividade na amostragem dos sedimentos em suspensão para a produção de curvas de sedimento, com consequências diretas nas recomendações para a sistematização do método.

Nesse contexto, questiona-se a representatividade do monitoramento proposto pela Resolução Conjunta da Agência Nacional de Energia Elétrica e da

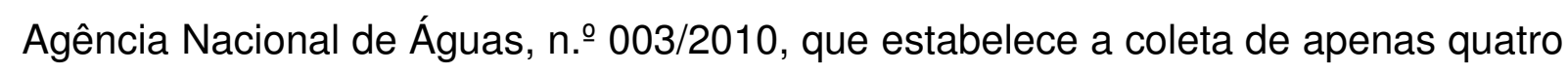
amostras de sedimento em suspensão por ano, para atualização de curvas de descarga sólida. Os resultados e discussões apresentados sugerem que, mais importante que estabelecer previamente o número de amostras, é fundamental conhecer as condições climáticas vigentes, planejar as campanhas baseadas em eventos e validar a representatividade das curvas em modelos dinâmicos.

A modelagem do transporte de sedimentos mostrou-se altamente dependente 
da gama de condições de escoamento abrangida durante o período de coleta de dados. Especialmente em pequenas bacias, não monitoradas, o emprego de métodos inconsistentes pode resultar na baixa representatividade do regime de transporte de sedimentos caracterizado.

Destaca-se, também, a necessidade de investimentos em monitoramento contínuo. Embora a manutenção de estações telemétricas continue a ser um desafio no Brasil, esse é, de fato, o principal obstáculo a ser superado para garantir dados representativos, em especial se incorporados sensores ópticos ou acústicos nos postos, capazes de fornecer dados diretamente correlacionáveis ao sedimento em suspensão.

Desde a elaboração do projeto básico da barragem de Taiaçupeba, na década de 1960, nenhum estudo hidrossedimentológico sistemático foi realizado no sistema fluvial. Dessa forma, a produção de dados primários para aplicação do modelo foi intensiva, uma vez que não havia dados históricos ou rede fluviométrica em operação que colaborassem com a sua calibração. Considerando-se a importância estratégica desse reservatório para a segurança hídrica da Região Metropolitana de São Paulo, destaca-se a necessidade de continuidade dos estudos, segundo as bases técnicas e científicas discutidas.

Conclui-se, por fim, que modelos unidimensionais de transporte de sedimentos ainda têm vasto campo de desenvolvimento e aplicação na pesquisa hidrossedimentológica. Apesar de suas bases teóricas serem sólidas, grande parte do ferramental disponível é empírico e o processo de aquisição de dados de campo é complexo, de modo que recentes avanços tecnológicos, ainda pouco difundidos no país, somados às recomendações metodológicas desta pesquisa, podem colaborar na garantia de dados primários consistentes e representativos. Além disso, uma vez calibrado, o modelo pode ser incorporado como uma ferramenta importante ao manejo de sedimentos e à resiliência de reservatórios. 
ACKERS, P.; WHITE, W. R. Sediment Transport: New Approach and Analysis. Journal of the Hydraulics Division, v. 99, n. HY11, p. 2040-2060, 1973.

AGÊNCIA NACIONAL DE ENERGIA ELÉTRICA. Guia de Avaliação de Assoreamento de Reservatórios. Brasília: ANEEL, 2000. 106p.

AMINI, A. et al. Comprehensive numerical simulations of sediment transport and flushing of a Peruvian reservoir. In: RESERVOIR SEDIMENTATION - SPECIAL SESSION ON RESERVOIR SEDIMENTATION OF THE 7TH INTERNATIONAL CONFERENCE ON FLUVIAL HYDRAULICS, RIVER FLOW 2014, 2014, Proceedings...CRC Press/Balkema, 2014. p. 211-219.

ASSELMAN, N. E. M. Fitting and interpretation of sediment rating curves. Journal of Hydrology, v. 234, n. 3-4, p. 228-248, jul. de 2000.

BAGNOLD, R. A. The flow of cohesionless grains in fluids. Phylosophical Transactions of the Royal Society of London, Series A, n. 249, p. 315-319, 1956.

BARNES JR, H. H. Roughness Characteristics of Natural Channels. Washington, D.C.: USGS, 1967. 213p. (U.S. Geological Survey Water-Supply Paper 1849).

BRUNE, G. M. Trap efficiency of reservoirs. Transactions, American Geophysical Union, v. 34, n. 3, p. 407-418, 1953.

BRUNNER, G. W. HEC-RAS River Analysis System Hydraulic: Reference Manual. Davis: USACE's Hydrologic Engineering Center, 2016. 538p.

BUCHANAN, T. J.; SOMERS, W. P. Discharge measurements at gaging stations. In: UNITED STATES GEOLOGICAL SURVEY. Techniques of Water-Resources Investigations of the U.S. Geological Survey: Book 3, Application of Hydraulics. Washington, D.C.: USGS, 1976. cap. A8. p. 1-65.

CARVALHO, N. O. Hidrossedimentologia Prática. 2.ed. Rio de Janeiro: Interciência, 2008.

CASTILLO, C. et al. Comparing the Accuracy of Several Field Methods for Measuring Gully Erosion. Soil Science Society of America Journal, v. 76, n. 4, p. 1319, 2012.

CASTILLO, L. G.; CARRILLO, J. M.; ÁLVAREZ, M. A. Complementary Methods for Determining the Sedimentation and Flushing in a Reservoir. Journal of Hydraulic Engineering, v. 141, n. 11, p. 1-10, 2015. 
CHURCHILL, M. A. Discussion of "Analysis and Use of Reservoir Sedimentation Data". In: PROCEEDINGS OF THE FEDERAL INTER-AGENCY SEDIMENTATION CONFERENCE, 1948, Denver, USA. Proceedings...Denver, USA: 1948. p. 139140.

COPELAND, R. R.; THOMAS, W. A. Corte Madera Creek Sedimentation Study. Sacramento: USACE, 1989. (Technical Report HL 89-6).

COPELAND, R. R. Numerical Modeling of Hydraulic Sorting and Armoring in Alluvial Rivers. 1993. 572f. Tese (Doutorado) - University of lowa, lowa City, 1993.

COSTA, S. B.; ARAUJO, T. B. de. Levantamento topográfico expedito de boçorocas com telêmetro a laser. In: CONGRESSO BRASILEIRO DE GEOLOGIA DE ENGENHARIA E AMBIENTAL - CBGE, 2013, Bento Gonçalves. Anais...Bento Gonçalves: ABGE, 2013. p. 1-9.

COSTA, S. B.; SOUZA, L. A. P. de; DEMARCO, L. F. W. Programa de monitoramento de controle dos processos erosivos e de assoreamento do reservatório de Taiaçupeba, SP - Fase de alteamento da barragem. São Paulo: IPT, 2017. 33p. (Relatório Técnico 150.607-205).

DAVIS, C. M. et al. Understanding Reservoir Sedimentation along the Rio Grande: A Case Study from Cochiti Dam. In: WORLD ENVIRONMENTAL AND WATER RESOURCES CONGRESS 2014, 2014, Reston, VA. Proceedings...Reston, VA: American Society of Civil Engineers, 2014. p. 2347-2357.

DEPARTAMENTO de ÁGUAS e energia ELÉTRICA. Sistema Produtor Alto Tietê. Disponível em: $<$ <ttp://www.daee.sp.gov.br/index.php?option=com_content\&view=article\&id=853:bar ragens-e-sistema-produtor-alto-tiete\&catid=36:programas $>$. Acesso em: $12 \mathrm{dez}$. 2015.

EDWARDS, T. K.; GLYSSON, G. D. Field Methods for Measurement of Fluvial Sediment. Reston: 1999. 89p. (Techniques of Water-Resources Investigations of the U.S. Geological Survey: book 3, chap. C2).

EINSTEIN, H. A. Formulas for the transportation of bed load. Transactions American Society of Civil Engineers, n. 117, p. 561-597, 1942.

EINSTEIN, H. A. The Bed-Load Function for Sediment Transportation in Open Channels. Washington, D.C.: U.S. Department of Agriculture, 1950. (Technical Bulletin No. 1026).

ELLISON, C. A.; SAVAGE, B. E.; JOHNSON, G. D. Suspended-Sediment Concentrations, Loads, Total Suspended Solids, Turbidity, and Particle-Size Fractions for Selected Rivers in Minnesota, 2007 through 2011. Reston: USGS, 2013. 43p. (Scientific Investigations Report 2013-5205). 
EMPRESA PAULISTA DE PLANEJAMENTO METROPOLITANO. Ortofotocartas do Projeto de Atualização Cartográfica do Estado de São Paulo. São Paulo: Emplasa, 2012.

ENGELUND, F.; HANSEN, E. A Monograph on Sediment Transport in Alluvial Streams. Copenhagen: Teknisk Forlag, 1967.

FEDERAL INTERAGENCY SEDIMENTATION PROJECT. Equipment used for sampling bed-load and bed material. lowa City: FISP, 1940. 57p. (Measurement and Analysis of Sediment Loads in Stream, Report No. 2).

FIGUEIREDO, E. O.; PAPA, D. de A. Mapeamento rural 3D de precisão com o uso do drone: a base para a vanguarda do planejamento florestal. In: CONGRESSO REGIONAL DE PESQUISA DO ESTADO DO ACRE, 2015, Rio Branco. Anais...Rio Branco: CNPq/Ufac/Embrapa/Fapac, 2015.

GARCÍA, M. H. Sediment Transport and Morphodynamics. In: GARCÍA, M. H. (Ed.). Sedimentation Engineering: Processes, Measurements, Modeling and Practice. Reston: ASCE, 2008. cap. 2. p. 21-163.

GIBSON, S. A.; PAK, J. H.; FLEMING, M. J. Modeling Watershed and Riverine Sediment Processes with HEC-HMS and HEC-RAS. In: WATERSHED MANAGEMENT CONFERENCE 2010: INNOVATIONS IN WATERSHED MANAGEMENT UNDER LAND USE AND CLIMATE CHANGE, 2010, Madison, Wisconsin. Proceedings....Madison, Wisconsin: ASCE, 2010. v. 394. p. 1340-1349.

GILL, M. A. Sedimentation and useful life of reservoirs. Journal of Hydrology, v. 44, p. 89-95, 1979.

GROTEN, J. T.; ELLISON, C. A.; HENDRICKSON, J. S. Suspended-Sediment Concentrations, Bedload, Particle Sizes, Surrogate Measurements, and Annual Sediment Loads for Selected Sites in the Lower Minnesota River Basin, Water Years 2011 through 2016. Reston: USGS, 2016. 29p. (U.S. Geological Survey Scientific Investigations Report 2016-5174).

HIRANO, M. River Bed Degradation with Armoring. Proceedings of Japan Society of Civil Engineers, n. 195, p. 55-65, 1971.

INMETRO. Vocabulário Internacional de Metrologia: conceitos fundamentais e gerais e termos associados (VIM 2012). 1.ed. Duque de Caxias: Inmetro, 2012. $94 p$.

INSTITUTO BRASILEIRO DE GEOGRAFIA E ESTATÍSTICA. Recomendações para Levantamentos Relativos Estáticos - GPS. Rio de Janeiro: IBGE, 2008.

INSTITUTO BRASILEIRO DE GEOGRAFIA E ESTATÍSTICA. O novo modelo de ondulação geoidal do Brasil: MAPGE02015. Rio de Janeiro: Coordenação de Geodésia, Diretoria de Geociências, 2015. 17p. 
INSTITUTO DE PESQUISAS TECNOLÓGICAS. Monitoramento da erosão e do assoreamento nas bacias hidrográficas dos rios Taiaçupeba, Biritiba Mirim e Paraitinga, SP. 2007. 104p. (Relatório Técnico 81.999-205).

KENDALL, M. G. Rank Correlation Methods. 4.ed. London: Charles Griffin, 1975.

LANDERS, M. N. et al. Sediment Acoustic Index Method for Computing Continuous Suspended-Sediment Concentrations. Reston: 2016. 63p. (U.S. Geological Survey Techniques and Methods, Book 3, Chap. C5).

LAURSEN, E. M. The total sediment load of streams. Journal of the Hydraulics Division, v. 84, n. HY1, p. 1530-1 1530-36, 1958.

LEVESQUE, V. A.; OBERG, K. A. Computing Discharge Using the Index Velocity Method. Reston: USGS, 2012. 148p. (U.S. Geological Survey Techniques and Methods 3-A23).

LIMERINOS, J. T. Determination of the Manning Coefficient From Measured Bed Roughness in Natural Channels. Washington, DC: USGS, 1970. 53p. (USGS Water-Supply Paper 1898-B).

MARENGO, J. A. et al. A seca e a crise hídrica de 2014-2015 em São Paulo. Revista USP, n. 106, p. 31, 2015.

MESELHE, E. A. et al. Numerical Modeling of Mobile-Bed Hydrodynamics of the Lower Mississippi River. In: WORLD ENVIRONMENTAL AND WATER RESOURCES CONGRESS 2010, 2010, Reston, VA. Reston, VA: American Society of Civil Engineers, 2010. p. 1433-1442.

MiNELLA, J. P. G.; MERTEN, G. H.; MAGNAGO, P. F. Análise qualitativa e quantitativa da histerese entre vazão e concentração de sedimentos durante eventos hidrológicos. Revista Brasileira de Engenharia Agrícola e Ambiental, v. 15, n. 12 , p. 1306-1313, 2011.

MONICO, J. F. G. Posicionamento pelo GNSS: descrição, fundamentos e aplicações. 2.ed. São Paulo: Editora UNESP, 2008. 476p.

MORRIS, G. L.; ANNANDALE, G.; HOTCHKISS, R. Reservoir Sedimentation. In: GARCÍA, M. H. (Ed.). Sedimentation Engineering: Processes, Measurements, Modeling and Practice. Reston: ASCE, 2008. cap. 12. p. 579-612.

MUELLER, D. S. et al. Measuring Discharge with Acoustic Doppler Current Profilers from a Moving Boat. Reston: USGS, 2013. 95p. (U.S. Geological Survey Techniques and Methods, Book 3, Chap. A22).

NAGHETTINI, M.; PINTO, É. J. de A. Hidrologia estatística. Belo Horizonte: CPRM, 2007. 552p. 
NASCIMENTO, C. E. de S.; KELMAN, J. Um modelo para geração estocástica de chuvas diárias. Revista Brasileira de Engenharia, Caderno de Recursos Hídricos, v. 13, n. 2, p. 19-36, 1995.

NASH, J. E.; SUTCLIFFE, J. V. River Flow Forecasting through conceptual models. Part I - A discussion of principles. Journal of Hydrology, v. 10, p. 282-290, 1970.

PARKER, G. Transport of Gravel and Sediment Mixtures. In: GARCIA, M. H. Sedimentation Engineering: Processes, Measurements, Modeling and Practice2. Reston: ASCE, 2008. cap. 3. p. 165-251.

PINZÓN, A. B. et al. The impressive case of the uncontrolled diversion of the Patía River at its Delta and the social and environmental consequences. In: 6TH SYMPOSIUM ON RIVER, COASTAL AND ESTUARINE MORHODYNAMICS, 2009, Santa Fe, AR. Santa Fe, AR: IARH, 2009.

PORTO, R. de M. Hidráulica básica. 4.ed. São Carlos: EESC-USP, 2006. 540p.

R DEVELOPMENT CORE TEAM. R: A language and environment for statistical computing. Vienna, Austria: R Foundation for Statistical Computing, 2008.

RASHID, M. U.; SHAKIR, A. S.; KHAN, N. M. Evaluation of Sediment Management Options and Minimum Operation Levels for Tarbela Reservoir, Pakistan. Arabian Journal for Science and Engineering, v. 39, n. 4, p. 2655-2668, 2014.

RYDLUND, P. H.; DENSMORE, B. K. Methods of practice and guidelines for using survey-grade global navigation satellite systems (GNSS) to establish vertical datum in the United States Geological Survey. Reston: 2012. 102p. (U.S. Geological Survey Techniques and Methods, book 11, chap. D1).

SABESP. Crise hídrica, estratégia e soluções da Sabesp para a Região Metropolitana de São Paulo. São Paulo: Sabesp, 2015. 95p.

SANTOS, M. S. T.; SÁ, N. C. de. O uso do GPS em Levantamentos Geofísicos Terrestres. Revista Brasileira de Geofísica, v. 24, n. 1, p. 63-80, 2006.

SERVIÇO DO VALE DO TIETÊ. Projeto básico da barragem do rio Taiaçupeba. São Paulo: DAEE, 1969.

SPASOJEVIC, M.; HOLLY JR., F. M. Two- and Three-Dimensional Numerical Simulation of Mobile-Bed Hydrodynamics and Sedimentation. In: GARCÍA, M. H. (Ed.). Sedimentation Engineering: Processes, Measurements, Modeling and Practice. Reston: ASCE, 2008. cap. 15. p. 683-761.

THOMAS, W. A. Mathematical modeling of sediment movement. In: HEY, R. D.; BATHURST, J. C.; THORNE, C. R. Gravel-bed Rivers. John Wiley \& Sons Ltd, 1982. cap. 18. 
THOMAS, W. A.; CHANG, H. Computational Modeling of Sedimentation Processes. In: GARCÍA, M. H. (Ed.). Sedimentation Engineering: Processes, Measurements, Modeling and Practice. Reston: ASCE, 2008. cap. 14. p. 649-681.

THOMAS, W. A.; COPELAND, R. R.; MCCOMAS, D. N. SAM Hydraulic Design Package for Channels. Washington, DC: U.S. Army Engineer Research and Development Center, 2002. 142p. (Final Report).

TOFFALETI, F. B. A procedure for computation of the total river sand discharge and detailed distribution, bed to surface. Vicksburg: USACE Committee on Channel Stabilization, 1968. (Technical Report No. 5).

TOPPING, D. J.; WRIGHT, S. A. Long-term Continuous Acoustical SuspendedSediment Measurements in Rivers-Theory, Application, Bias, and Error. Reston: 2016. 98p. (U.S. Geological Survey Professional Paper 1823).

TORO-ESCOBAR, C. M.; PAOLA, C.; PARKER, G. Transfer function for the deposition of poorly sorted gravel in response to streambed aggradation. Journal of Hydraulic Research, v. 34, n. 1, p. 35-53, 1996.

TRIGG, M. A. et al. Amazon flood wave hydraulics. Journal of Hydrology, v. 374, n. 1-2, p. 92-105, jul. de 2009.

WERNLY, J. F.; ZAJD JR, H. J.; COON, W. F. Bathymetric Survey and Estimation of Storage Capacity of Lower Sixmile Creek Reservoir, Ithaca, New York. Reston: USGS, 2016. 13p. (U.S. Geological Survey Open-File Report 2016-1157).

YANG, C. T. Incipient motion and sediment transport. Journal of Hydraulic Division, v. 99, n. 10, p. 1679-1704, 1973.

YANG, C. T. Unit stream power equation for gravel. Journal of Hydraulic Division, v. 110, n. 12 , p. $1783-1797,1984$.

YUE, S. et al. The influence of autocorrelation on the ability to detect trend in hydrological series. Hydrological Processes, v. 16, n. 9, p. 1807-1829, 2002. 


\section{APÊNCIDE A - PLANO DE GESTÃO DE DADOS}

O presente Plano de Gestão de Dados tem como premissa assegurar a integridade dos dados e registros desta pesquisa, aumentando seu potencial de replicação e permitindo que sejam compreensíveis e recuperáveis, no futuro, para permitir avanços no conhecimento científico e tecnológico.

\section{A1 PRESERVAÇÃO E COMPARTILHAMENTO}

Os dados encontram-se preservados em repositório digital de dados, publicamente disponível desde 15 de outubro de 2017, por tempo indeterminado, no endereço https://figshare.com/projects/Taiacupeba Sediment Model/25723. Todo o conteúdo é apresentado na língua inglesa, para garantir compartilhamento em nível internacional.

\section{A2 DESCRIÇÃO DOS DADOS}

O repositório contém os seguintes conjuntos de arquivos:

- Sediment Data: arquivos em formato CSV contendo pares de dados de concentração de sedimentos em suspensão e vazão, granulometria do sedimento do leito e descrição dos postos fluvissedimentométricos;

- Streamflow Records: arquivos em formato CSV contendo as séries de vazões diárias utilizadas na simulação do modelo de fundo móvel;

- Cross Sectional Survey: arquivos em formato CSV contendo pares ordenados de distância transversal e cota altimétrica das seções, limites dos canais principais e coordenadas UTM das seções levantadas;

- Statistical Data Analysis using R: scripts em linguagem R contendo rotinas de cálculo para curvas de permanência de vazões, análise de regressão não linear para curvas de sedimento e teste de tendência de séries temporais, incluindo resultados gráficos;

- HEC-RAS Steady and Quasi-Unsteady Flow Files: arquivos em formato proprietário do software HEC-RAS, contendo o projeto principal (PRJ), 
dados de geometria do sistema fluvial $\left(\mathrm{G} 0^{\star}\right)$, dados para cálculo do escoamento em regime permanente $\left(\mathrm{FO}^{*}\right)$ e quase permanente $\left(\mathrm{Q} 0^{*}\right)$, condições de contorno sedimentológicas $\left(\mathrm{SO}^{*}\right)$ e planos de simulação $\left(\mathrm{PO}^{*}\right)$.

Todas as unidades encontram-se no Sistema Internacional de Medidas e os separadores decimais definidos por pontos (“.”), para fins de compatibilidade com o ambiente estatístico R e software HEC-RAS.

\section{A3 RESTRIÇÕES LEGAIS}

Todos os dados foram registrados sob a licença pública Creative Commons Attribution 4.0 International - CC BY 4.0, que permite seu uso, distribuição e reprodução em qualquer meio, sem restrições, desde que a pesquisa original seja devidamente citada.

Os scripts em linguagem $\mathrm{R}$ estão registrados sob a licença permissiva MIT, concedendo direitos de uso, cópia, modificação, mesclagem, publicação e distribuição, no estado em que se encontram, sem garantia de qualquer tipo, expressa ou implícita, eximindo a responsabilidade do autor por qualquer reclamação, dano ou outra responsabilidade, seja em ação de contrato, delito ou outra forma, relacionado com o uso dos códigos. 